University of San Diego

Digital USD

Theses

Theses and Dissertations

Summer 8-31-2016

\title{
The "Rib" of the South? An Analysis of Feminine Agency Among Southern Elite Women of the Antebellum Period (1815-1860)
}

Louann Marie Sabatini

Follow this and additional works at: https://digital.sandiego.edu/theses

Part of the History of Gender Commons, United States History Commons, and the Women's History Commons

\section{Digital USD Citation}

Sabatini, Louann Marie, "The "Rib" of the South? An Analysis of Feminine Agency Among Southern Elite Women of the Antebellum Period (1815-1860)" (2016). Theses. 11.

https://digital.sandiego.edu/theses/11

This Thesis: Open Access is brought to you for free and open access by the Theses and Dissertations at Digital USD. It has been accepted for inclusion in Theses by an authorized administrator of Digital USD. For more information, please contact digital@sandiego.edu. 
University of San Diego

The "Rib" of the South?

An Analysis of Feminine Agency Among Southern Elite Women of the Antebellum Period (1815-1860)

A Thesis submitted in partial satisfaction of the requirements for the degree of Master of Arts in History

\author{
by \\ Louann Marie Sabatini
}

\author{
Thesis Committee \\ Michael J. Gonzalez Ph.D., Chair \\ David Miller, Ph.D.
}


The Thesis of Louann Marie Sabatini is Approved by:

Thesis Committee Chair

Thesis Committee Member

University of San Diego

San Diego

2016 
Copyright 2016 Louann Marie Sabatini

Limitations: No part of this document may be reproduced in any form without the author's prior written consent for a period of three years after the date of submittal.

Louann Marie Sabatini 
INDEX.

ii-iii

TABLE OF CONTENTS .................................................................... iv

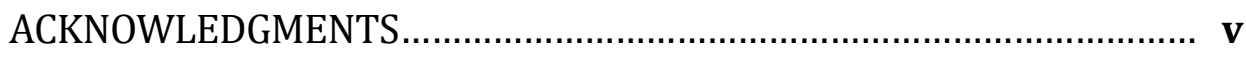

AREAS OF STUDY ..................................................................... vi

AN INTRODUCTION

1) CHAPTER ONE: SOUTHERN DOMESTICITY-

POWER, AGENCY, AND IDENTITY ……………………........ 17-56

2) CHAPTER TWO: AGENCY IN PUBLIC ACTIVISM-

SOUTHERN ELITE WOMEN IN THE PUBLIC SPHERE ................. 57-79

3) CHAPTER THREE: A WORLD OF THEIR OWN-AGENCY WITHIN THE SOUTHERN FEMININE COMMUNITY.................................... 80-101

4) CHAPTER FOUR: CONCLUSIONS......................................... 102-112

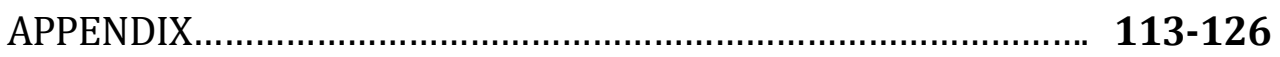

BIBLIOGRAPHY ..................................................................... 127-141 
"If I have seen further, it is by standing on the shoulders of giants."

-Isaac Newton

This work would not have been possible without the following people. Thank you to Dr. Gonzalez for supervising this thesis and helping me achieve this goal. In addition, thank you to Dr. Miller for acting as my second reader, and for the wonderful input he has given me for my topic. I am forever indebted to the both of you, and I will never forget your efforts. Last, thank you to my family and friends for their constant support, and inspiring me every day. Thank you all.

-Louann 


\section{AREAS OF STUDY:}

Virginia, North Carolina,

South Carolina, Georgia,

Alabama, and Louisiana.

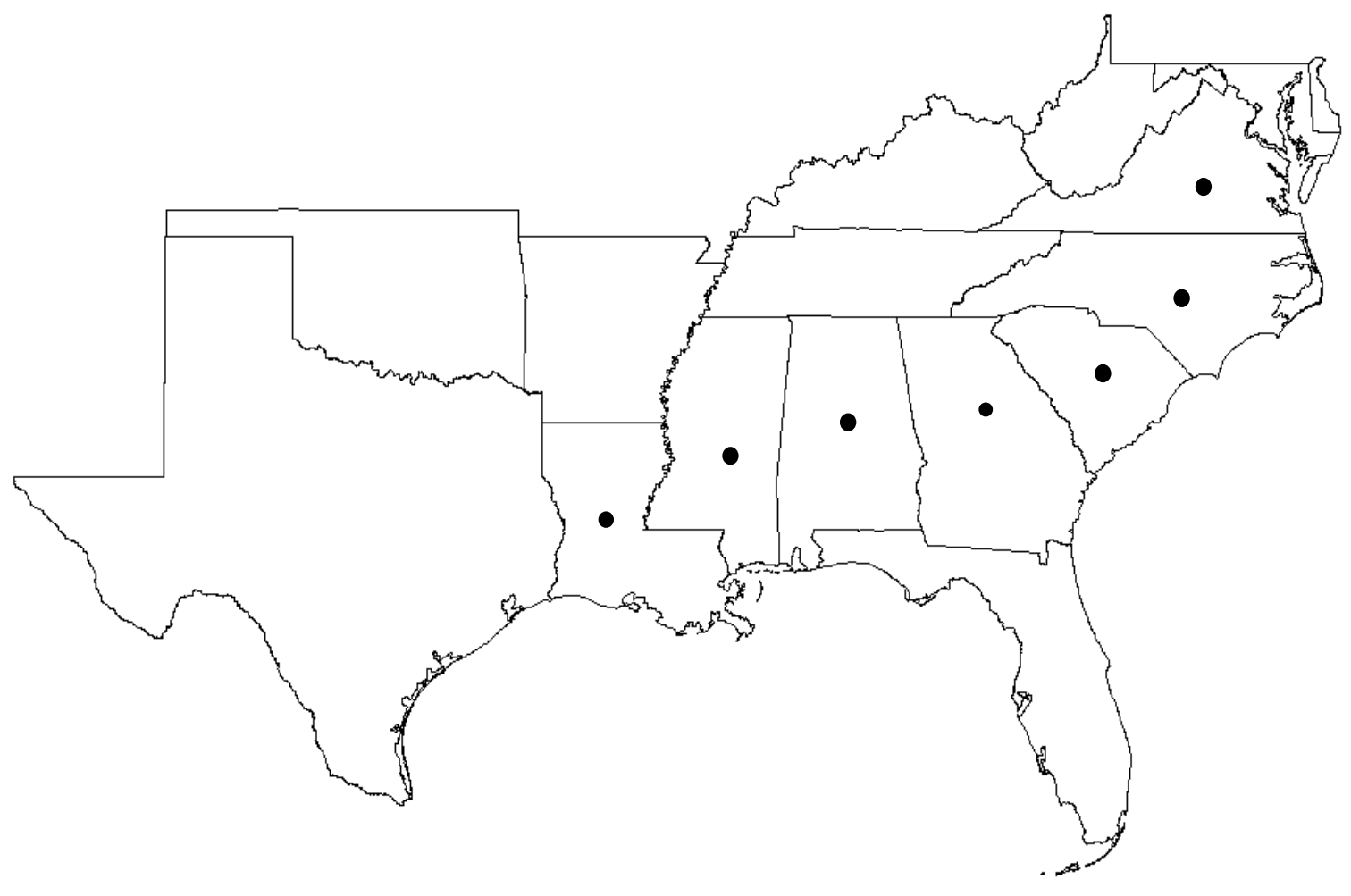


INTRODUCTION 
The scholarship concerning white Southern women is one of the most significant areas of investigation in Southern United States history. Scholars addressed issues concerning Southern females that included examinations of gender ideologies, slavery, female social relations, feminine politics, and the impact of the Civil War on societal norms. Among this research, a problematic consensus stands: Southern elite women's autonomy was weak or nonexistent in the antebellum period; yet this thesis suggests otherwise. Challenging this view, I argue that prior to the Civil War elite mistresses discovered agency, independence, and identity among themselves within the roles of "Southern Domesticity", “Moral Reform", and "Southern Sisterhood".

Investigating women in American history requires a multidisciplinary approach. Academics in "Women Studies" research feminine identities through race, gender, sexuality, and class. Scholars in "Feminist Theory" explore gender inequality by using theoretical and philosophical approaches to understand women's social roles, motivations, and experiences. These investigations draw from disciplines such as anthropology, sociology, post-structural theory, political science, economics, and literature. Moreover, researchers focused on "Women's History" document the role females have played in history. No matter the discipline, most scholars agree that feminism is a mentality that promotes feminine equality within various social areas. Academics also contend that women developed a feminine consciousness from the understanding that their gender had always been the less valued in society. Most females who were aware of their subjugation seemed to follow a distinct path toward change. First, 
they had to be socially oppressed. ${ }^{1}$ Second, they began to feel the effects of these restrictions, became self-aware, and eventually developed a need to change their status through large or small actions. Eventually, many of these women reinvented themselves or initiated small changes throughout their lives.

Some of the first academic investigations of American womanhood and feminism involve New England women. According to researchers, feminism developed due to the widening gap between male and female social spheres and strictly enforced gender expectations that occurred from major structural influences such as the Industrial Revolution of the nineteenth-century. ${ }^{2}$ During the seventeenth and eighteenth centuries, however, gender ideologies were inconsistently imposed within colonial America as seen in the parallels of male and female social responsibilities during this period, but also their willingness to perform each other's tasks as well. As a result, the fusion of responsibilities equalized the aspirations of men and women, particularly among females. Indeed, women felt a sense of purpose and equality working alongside their families as integral contributors to their families. By the nineteenth-century structural changes brought about the Industrial and Market Revolutions, fragmenting the American household and prohibited women from performing responsibilities they had done previously. As a result, discontented housewives held fewer duties and were isolated to specific gendered tasks that left them

${ }^{1}$ Catherine Clinton, The Plantation Mistress: Women's World in the Old South (New York: Pantheon Books, 1982).

2 Nancy Cott, The Bonds of Womanhood: "Woman's Sphere" in New England 1780-1835 (New Haven: Yale University Press, 1977), chapters 1-4. 
with few aspirations and little self-worth. By contrast, working class women did not have the luxury of housewifery, which omitted them from this mentality and allowed them to be more independent as well. ${ }^{3}$ In response, middle class females sought to find fulfillment in their lives by advocating for the social privileges of the uneducated, orphaned, enslaved, imprisoned, and mentally ill. Additionally, these bourgeois women joined religious groups to search for meaning in their roles as mothers and wives.

The roles of "Mother" and "Moral Reformer" gave New England women the ability to maneuver within their social boundaries to educate, empower, and elevate each other. They reformed the structural issues with public education to increase female attendance at learning institutions, allow girls to learn beyond their teenage years, and permit females to receive advanced academic lessons; knowledge was power and in the hands of women, it instilled strength. ${ }^{4}$ Similarly, women exploited the social power of religion to encourage female agency and social elevation. Often, they entered the public sphere under a moral religious "cloak", and upheld "proper" social expectations, to fight for social progress or promote their religious values. Inadvertently, however, they discovered social independence, developed a forum for feminist collaboration, and performed duties outside their gender roles. ${ }^{5}$ Finally, women experienced self-fulfillment, independence, and individuality in domestic responsibilities

\footnotetext{
${ }^{3}$ Christine Stansell, City of Women: Sex and Class in New York, 1789-1860 (Illinois: University of Illinois Press, 1987).

${ }^{4}$ Margaret Fuller, Women in the Nineteenth Century (New York: Greeley and McElrath, 1845).

${ }^{5}$ Elizabeth Cazden, Antoinette Brown Blackwell: A Biography (New York: The Feminist Press, 1983); Cott, chapter 3.
} 
such as "Republican Motherhood", which were missing in other areas of the female sphere. ${ }^{6}$ By the mid nineteenth-century, women transferred this fight from the private sector to the public, initiating a battle for women's civil rights. Undeniably, this early resistance influenced the way women valued themselves and pushed the boundaries of American womanhood as the North changed from a rural economy to an industrial and urban society in the early nineteenthcentury.

Some notable studies of New England women and feminism include Christine Stansell's research on the harsh reality and complicated social relations of nineteenth century "working” females, Carroll Smith-Rosenberg's investigation of New England women's non-normative social roles, and Laurel Ulrich's survey of the conflicting ideology between the image and reality of colonial New England women. ${ }^{7}$ Additionally, Nancy Cott's examination of the origins of nineteenth century womanhood and feminine agency in The Bonds of Womanhood continues to be one of the most prominent works on women and feminist theory in early America. Aside from these scholars, the body of research on New England women and feminism is extensive and detailed, revealing the process, development, and consequences of gender resistance.

\footnotetext{
${ }^{6}$ Cott, chapter 4.

${ }^{7}$ Stansell, City of Women; Laurel Thatcher Ulrich, Good Wives: Image and Reality in the Lives of Women in Northern New England, 1650-1750 (New York: Vintage Books, 1991); Carroll SmithRosenberg, Disorderly Conduct: Visions of Gender in Victorian America (New York: Oxford University Press, 1985).
} 
By contrast, drastic social transformation did not necessarily exist in the South until after the Civil War, nor did the social position of elite plantation women decrease as it did for Northern females. Within Southern agrarian culture, elite citizens continued to live a way of life that stressed both business and home in one sphere, but also emphasized that the roles of mother and father were equal and contributing factors to the nuclear family and Southern culture. Both males and females in the South were still very much involved in the prosperity, protection, and integrity of the "family" business and survival of the family unit. On this foundation, Southern women possessed greater autonomy, independent, and social purpose than their New England counterparts. Indeed, elite Southern females experienced a drastically different lifestyle that greatly influenced how they acquired meaning and importance in their lives and in American society.

More important, the study of American women holds a fraction of investigations concerning Southern females compared to the research of New England women. The works of Anne Firor Scott, Julia Cherry Spruill, Catherine Clinton, Suzanne Lebsock, Elizabeth Fox-Genovese, Stephanie McCurry, LeeAnn Whites, Drew Gilpin Faust, Elizabeth Varon, Laura F. Edwards, and Thavolia Glymph are some of the best and most comprehensive investigations concerning Southern female perspectives that we have thus far. These studies examined plantation women who lived on large estates that produced vast commodities dependent on fifty slaves or more. In addition, they found that these females were extremely regulated, and distinct in their appearances and social manners 
from their lower class counterparts. ${ }^{8}$ Most of these scholarships have concluded that Southern women never experienced feminist sentiments or the feminist movement throughout the nineteenth-century. Unfortunately, arguing that feminism did not exist among these females diminishes the social complexities of Southern ladies, and dismisses them from feminist theory. Accordingly, it is more important we highlight that Southern women were feminists because they fought to maintain their autonomy in the South and solidified the female position in Southern culture by challenging their societal norms in unique ways.

In 1970, Anne Scott presented one of the first histories of Southern women in The Southern Lady: From Pedestal to Politics. ${ }^{9}$ Examining the years from 1830 to 1930, she challenged the accepted image of Southern women by substantiating their involvement in politics. Scott argued, "Records of political reform movements revealed a group of women who had played a significant role...there she was, active and effective."10 Shattering the myth of the "southern belle," she indicated that females were not only active in Southern politics during the nineteenth and twentieth centuries, but that their actions also represented a very real understanding that Southern elite women were much more than housewives. According to Scott, they were activists and feminists as well.

\footnotetext{
${ }^{8}$ Clinton, chapters $1-3$.

${ }^{9}$ Anne Firor Scott, The Southern Lady: From Pedestal to Politics, 1830-1930 (Chicago: University of Chicago Press, 1970).

${ }^{10} \mathrm{Ibid}, 5$.
} 
Scott examined female agency and social activism using the microanalysis of familial relations, political activities, the impact of the Civil War, and the domestic sphere in order to represent how truly dynamic these females were in the South. Of all these areas of study, her examination of the Civil War's effects on gender definitions was the most impressive part of her scholarship. She found, "When women are forced into new spheres, or voluntarily choose callings hitherto barred to the sex, they grow in versatility and self-reliance, and are also stimulated by their new duties."11 Most scholars of Southern history agree that the Civil War transformed American society, though some disagree how and to what degree this conflict influenced gender roles. Scott suggested the Civil War altered Southern womanhood substantially and challenged gender norms. Even more, she demonstrated how truly parallel the social experiences of Southern and Northern women were as well.

Yet, despite how fundamental Scott's work is, it does have a few issues. Her evidence inadvertently suggests that Southern women maintained female agency through their political activities, yet "most southern women would not have tried, or known how, to free themselves from the system which was supposed to be divinely ordained, but there is considerable evidence that many of them found the "sphere" very confining." 12 In addition, Scott's analysis of political activism from the 1880s to 1930 was much stronger than

11 Scott, 133.

12 Ibid, 46. 
her examination during the antebellum years. ${ }^{13}$ Even so, it hardly overshadows the importance of her work, and its applicability to Southern feminism.

Challenging Anne Scott's work, Catherine Clinton investigated the social perspectives of Southern elite women during the antebellum period in The Plantation Mistress. Clinton's evidence centered “on women in residence on plantations with twenty slaves or more" and consisted of "nearly five hundred manuscript collections...fifty-five years following the American Revolution...for 750 individuals of the planter class." ${ }^{14}$ She surveyed numerous facets of elite Southern females' lives and Southern womanhood, and initiated the study of women in the American South. Indeed, this scholarship is an excellent foundation for new investigations.

Still, this work took many steps back in its interpretation of Southern women and feminism. One, her work denied that feminine agency existed in the American South. Clinton argued plantation women did not experience feminine agency or social freedom due to their limited social sphere and extreme isolation. She claimed:

Plantation mistresses often felt unrecognized and emotionally unfulfilled...rarely seized control within any of their severely restricted spheres, and most plantation mistresses never escaped the literal or behavioral confines of their circumscribed world...The plantation mistress...had no comparable sense of community. ${ }^{15}$

\footnotetext{
${ }^{13}$ Scott, 3-44.

${ }^{14}$ Clinton, xiv, xiii.

15 Ibid, $164 \& 230$.
} 
By presenting a very dismal reality of these women's lives and their social status, but also assuming they had no power to change these circumstances, she generalized the lives of plantation females and validated the restrictiveness of Southern society. In actuality, Southern females did experience a sense of community and her investigation does little justice to this idea. Clinton's goal was to explore "plantation mistresses' contributions to the ante-bellum South" and "finally gain for them what they have so long been denied: recognition, acknowledgment-at long last, a history." 16 The question remains however, what type of recognition? What type of history did they seek?

Concerned with the lack of historiography regarding multiracial relations among nineteenth-century women, Elizabeth Fox-Genovese discussed the complicated identities and relationships among Southern elite women and their female slaves in Within the Plantation Household. ${ }^{17}$ Her scholarship surveyed the intricate lives of these females-motherhood, social relations, friendship, class hierarchy, and gender suppression. She argued, "In this book, I have purposed to tell the story of black and white women of the southern plantation household...and, along the way, to make a modest contribution to Southern and women's history."18 This investigation is unique since no previous scholarship investigated these females in such detail. She explained, "The privileged roles and identities of slaveholding women depended upon the

\footnotetext{
${ }^{16}$ Clinton, 15.

${ }^{17}$ Elizabeth Fox-Genovese, Within the Plantation Household: Black and White Women of the Old South (Chapel Hill: University of North Carolina Press, 1988).

18 Ibid., 29.
} 
oppression of slave women, and the slave women knew it."19 Most certainly, this aspect of her examination was groundbreaking, and contributed even more detail to the study of black and white women in America.

Moreover, Fox-Genovese's research highlighted the importance of an investigative technique that was highly criticized by scholars of women's history and feminist theory. She analyzed African-American and Caucasian women through the prisms of race, class, and gender. Some historians say using race and class to understand feminism and women's perspectives weakens the discipline's integrity and supports only male centric views of societies. ${ }^{20} \mathrm{In}$ contrast, Fox-Genovese believed it was a necessity since, "the tendency to generalize the experience of the women of one region to cover that of all American women has obscured essential differences of race and class...All women, like all men, are a product of social relations defined to include gender, class, nationality, and race." ${ }^{21}$ Her work truly emphasizes how important it is to explore most topics in history through these three four classifications.

Still, there are a few limitations in her study as well. She spoke very little about feminism and feminine agency influencing these women. Fox-Genovese stated, "They did not commonly bemoan this social and economic position...Their protests against...the system rarely amounted to a systematic defense of the rights of women as women."22 Also, incorporating more evidence

\footnotetext{
${ }^{19}$ Fox-Genovese, 35.

20 Ibid., 42.

21 Ibid., 40, 42.

22 Ibid., 96.
} 
of elite women's political activism would have solidified her work even more. Nevertheless, Fox-Genovese's investigation transcended previous scholarship, and demonstrated the complex social link between black women and white women, thus contributing significantly to the study of American females.

Women of the Confederacy glare from photographs in Drew Gilpin Faust's Mothers of Invention. According to Faust, Southern women seemed loyal to their families and sense of duty, yet they truly struggled to form a balanced life after the Civil War. She believed, "elite women of the Confederate South...struggled to cope with the destruction of a society that had privileged them as white, yet subordinated them as females." ${ }^{23}$ Highlighting the complexities of this social paradox, Faust searched for answers among the popular discourse of the period and personal records of 500 Confederate females. ${ }^{24}$ Her evidence ranged from songs to live performances to diaries and letters, revealing a group of highly intelligent females who struggled to maintain their identity and culture. She argued, "They sought to invent new foundations for self-definition and self-worth as the props of whiteness, wealth, gentility, and dependence threatened to disappear."25 In turn, she found that elite Southern women returned to traditional gender roles in order to salvage their culture after the war.

\footnotetext{
${ }^{23}$ Drew Gilpin Faust, Mothers of Invention: Women of the Slaveholding South in the American Civil War (Chapel Hill: University of North Carolina Press, 1996), 7.

${ }^{24}$ Ibid., xii.

25 Ibid.
} 
As a result, Faust did not believe Southern elite women found autonomy or agency within their sphere because they defended their culture instead of abandoning it. She stated, "In the South, by contrast, emergent nineteenth century feminism had by 1861 exerted almost no impact, and understandings of womanhood had remained rigidly biological and seemingly natural."26 Although she demonstrated how the Civil War influenced Southern gender definitions, she also insinuated that these women did not feel it was necessary to fight for equality within Southern culture after the war. Instead, their efforts to memorialize and commemorate their fallen men in the Reconstruction period, to protect Southern culture from Northern aggression, seemed to validate her point. In Burying the Dead but Not the Living, Caroline Janney validates that Southern elite women's commemorative efforts were directed toward discovering power and meaning in womanhood, as much as those behaviors were to fight for the "old south" once again. ${ }^{27}$ Yet, Faust's research is valid, and even with this issue it represents the Civil War's impact on the Southern social order, and particularly gender definitions.

Finally, Elizabeth Varon argued in her scholarship, We Mean to be Counted, that women of the South were much more active in the public sphere than most scholars acknowledged, especially in civic reform efforts. ${ }^{28}$ She claimed "elite and middle-class women played an active, distinct, and evolving

\footnotetext{
26 Faust, 6.

${ }^{27}$ Caroline E. Janney, Burying the Dead but Not the Past: Ladies Memorial Associations and the Lost Cause (Chapel Hill: University of North Carolina Press, 2008), 53.

${ }^{28}$ Elizabeth Varon, We Mean to Be Counted: White Women and Politics in Antebellum Virginia (Chapel Hill: University of North Carolina Press, 1998).
} 
role in the political life of the Old South." 29 Drawing from an array of literary sources-newspapers, civic club documents, and personal discourse-Varon analyzed these women through their association with various reform movements such as the Whig party, the American Colonization Society, and various orphan societies. According to Varon, these females were lobbyists, activists, business women, and politicians aside from their roles as wives and mothers. This multi-layered perspective demonstrates the complexities and capabilities of Southern elite women, and counters Clinton's assumptions.

Nonetheless, there are two inconsistencies with Varon's scholarship. She argued, "Virginia women gradually withdraw their support from national political causes and embrace sectional ones" and "sought, each in her own way, to resolve an enduring paradox - to reconcile a commitment to the traditional gender order, in which women deferred to the leadership of men, with a passion for politics and a desire to be heard."30 Varon agreed with Faust that Southern women faltered between improving their social status and preserving their culture, yet ultimately reverted to their gender traditions. As such, her work dismissed the idea that feminism occurred in the South, and argued that women returned to the control of elite males. Even more, her findings are not indicative of all Southern women but specifically those who lived in Virginia, which limited

${ }^{29}$ Varon, 43.

${ }^{30}$ Ibid., 143 and 155. 
her investigation. Despite these problems, Varon's research is fundamental to the study of Southern women.

In sum, much of the current historiography on Southern elite women separates these females from the feminist agenda. Yet, my analysis positions them back in the history of American Feminism. Contrary to previous assumptions, Southern feminine agency existed and followed a distinctly different pattern. Did Southern elite women foster a feminine mentality and find agency within their private and public spheres? Yes.

This research demonstrates Southern elite women's efforts to hold authority over their social status as well as their fight to maintain autonomy and control over themselves. Chapter One investigates the ways mistresses_fostered agency within their responsibilities in the domestic sphere, specifically as "Domestic Overseer", “Slave Mistresses”, and “Mother." Chapter Two, researches how the role of "Southern female activist" allowed these females to push gender boundaries to find power within their social efforts. Chapter Three looks at the theoretical domain of the female community that existed among these women, and explains how Southern women found agency and self-sufficiency in their lives outside the home. In essence, this is an investigation that concerns Southern elite women's ability to be women, first, and mothers and wives second. It is also a new way to evaluate Southern females in relation to feminism and agency in the American South. 
It is time that scholars acknowledge Southern elite females in feminist history, and represent these ladies as multidimensional individuals who transcended their social confinement. The narratives of these women do "not constitute another regional variation on the main story; it constitutes another story." 31 We need to recognize such complicated, yet fascinating females, and bring them into the focus of feminist scholarship.

31 Fox-Genovese, 42. 


\section{CHAPTER ONE}

\section{SOUTHERN DOMESTICITY: POWER, AGENCY, AND IDENTITY}

"By molding possibilities, imaginary worlds can inspire new actions; or, paradoxically, their alternative pleasures can encourage escape and a withdrawal from action." 32

${ }^{32}$ Dorothy Holland, William Lachicotte Jr., Debra Skinner, and Carol Cain, Identity and Agency in Cultural Worlds (Cambridge: Harvard University Press, 1998), 49. 
Elite women of the South, as domestic overseers, experienced the daunting task of running the Southern household as efficiently as possible, while also playing the role of dutiful wife, mother, and slave mistress. Some of their responsibilities included organizing the home, ordering household supplies, entertaining guests, and performing business transactions in their husbands' absence. Although scholars believe women were continually under the subordination of their spouses and that many of these tasks limited women's abilities, evidence in this chapter suggests that mistresses maintained individuality and dominance in their lives through the role of domestic manager. They were not servants to this patriarchal world, but instead integral partners and protectors of the nuclear family and Southern culture, exercising as much influence over themselves and their identity as did the men in their lives.

\section{Background}

Before analyzing the Southern domestic sphere in the 1800 s, it is important to recognize that Southern women's social role has long been an important contribution to the success of Southern families and their culture, and this mentality prevailed in Southern women in the nineteenth-century. Undeniably, Southern elite women were in a position where their work was important and powerful within this culture, and this sense of purpose instilled strength and autonomy among them. From the 1600s through the 1700 s, women's social experiences varied from colony to colony among gender, religious, political, and cultural ideologies. Females who lived in the "French" 
territories of Mississippi and Louisiana experienced similar gender expectations, to some degree, as did their counter parts in the English colonies as well. In Northern settlements, Puritans and Quakers held strong religious values which dictated a woman's subordination to her husband and family. This culture valued, more than anything else, an obedient wife who took care of her family while living a very simple and selfless lifestyle. ${ }^{33}$ In fact, many New England families worked small plots of land, in comparison to other colonists who operated more extensive properties and more time-consuming chores. The result was a very regulated and limited female world, where religion and making penance occupied their time more than monetary ventures or agrarian responsibilities.

On the other hand, while Puritan religious zeal took over New England, and Quaker ideals embodied the lifestyle of the middle colonies, the South became a full-fledged cash cropping society that supplied goods for colonists and overseas merchants. Indeed, Southern colonies such as Virginia, North Carolina, South Carolina, Georgia, Maryland, and Delaware focused less on religion and more on economic demand that supplied colonists and their home countries with prized commodities such as tobacco, cotton, rice, and indigo. ${ }^{34}$ Based on this trade and manufacturing business, male and female gender ideologies became mutually exclusive since nothing was accomplished without

33 Barry Levy, Quakers and the American Family: British Settlement in the Delaware Valley (Oxford: Oxford University Press, 1988); John Demos, A Little Commonwealth: Family Life in Plymouth Colony (Oxford: Oxford University Press, 2000).

${ }^{34}$ Wesley F. Craven, The Southern Colonies in the Seventeenth Century, 1607-1689: A history of the South (Baton Rouge: Louisiana State University Press, 1949), 56. 
everyone working together for survival, wealth, and perpetuating this system, which inadvertently tied the household to the family business. ${ }^{35}$ In turn, Southern women's roles were much more detailed and considered integral to the Southern household because men and children relied heavily on their labor. As such, these females held their social position in great esteem, and families understood that both male and female roles were equal and important.

Indeed, Southern women played pivotal parts in the settlement, protection, and prosperity of Southern colonial families as mothers, wives, and workers. Dr. Lee Caldwell's study of colonial women who resided in Georgia, confirms this idea. She stated, "In addition to their reproductive labor, women were also producers, running households, preparing food and clothing, and helping with planting and harvesting when necessary." ${ }^{36}$ It was difficult to survive without their assistance. For instance, cooking for a large family took daily and weekly preparation because women had to acquire the food and prepare it utilizing very laborious techniques and instruments such as a large hearth. Cooking began in the early morning and ended fairly late at night, often requiring that women multitask on each part of the meal; and they did this at

35 Daniel Blake Smith, Inside the Great House: Planter Family Life in Eighteenth-Century Chesapeake Society (Ithaca: Cornell University Press, 1980), pp. 25-55, 55-82 \& 231-249; Kathleen Brown, Good Wives, Nasty Wenches, and Anxious Patriarchs: Gender, Race, and Power in Colonial Virginia (Chapel Hill: University of North Carolina Press, 1996); T. H. Breen, Tobacco Culture: The Mentality of the Great Tidewater Planters on the Eve of Revolution (Princeton: Princeton University Press, 1985); Darrett R. Rutman, A Place in Time: Middlesex County Virginia (Toronto: George J. Mclead Limited, 1984); Carol Berkin, First Generations: Women in Colonial America (New York: Hill and Wang, 1996); Julia Cherry Spruill, Women's Life and Work in the Southern Colonies (New York: W.W. Norton \& Company, 1972), pp. 20-43. ${ }^{36}$ Lee A. Caldwell, "Women in Colonial Georgia" in the New Georgia Encyclopedia (09 December 2015). 
least twice a day. It was no easy task, but a very important one since it nourished their families and kept them healthy. In addition, women had to preserve items for long winters or periods when commodities were absent, requiring them to plan how much to store away, how to cure various foods, and find the necessary materials to complete this job. They canned fruit, vegetables, nuts, and salted meats among other edibles. ${ }^{37}$ Even more with no refrigeration, dairy production was a major undertaking since perishable items had to be processed daily, and women worked to preserve milk, churn butter, and milked the cows among other things. Finally, laundry was one of the most time-consuming events that entailed making and stripping beds, and washing, drying, and folding every piece of fabric in the house. If they possessed servants and slaves, it was an even greater task since this meant they had more to clean. Still, some might question whether it was easier for these women to have slaves that performed these tasks. However, slaves were difficult to come by in the colonies until the midseventeenth century due to their necessity in the West Indies. ${ }^{38}$

Yet, protecting their homes and mentoring their children were probably the greatest activities that women performed during this period. ${ }^{39}$ Family and reproduction formed the most important aspects of Southern colonial families. Lee Caldwell agreed, "Children also contributed to growth and stability in the

37 Refer to Patricia B. Mitchell's, At the Table in Colonial America: 1700-1776 (Sims-Mitchell House \& Breakfast, 1999).

${ }^{38}$ Betty Wood, The Origins of American Slavery (New York: Hill and Wang, 1991); Alan Gallay, The Indian Slave Trade: The Rise of the English Empire in the American South 1670-1717 (New Haven: Yale University Press, 2002).

${ }^{39}$ Refer to figure 17 in appendix. 
colony, and having 'fine' children was one of the important functions of wives." 40 It also helped to have children as free labor around the house too. Moreover, Karin Calvert's research on American children, between 1600 to1900, further validates the role of mother was extremely important in colonial America. For example, she researched this idea through observing that boys and girls were dressed, from infancy to the age of seven, identical to their mothers, fostering strong bonds between one another, and emphasizing how important the role of "mother" was to the Southern household. Overall, the evidence that exists on Southern colonial women reassures us that the matriarchs' position in the American South had always been powerful and important to American society. Even more, women felt the burden of this vital social status, and often identified as independent and strong Southern females because of it.

Southern colonial women not only felt the seriousness and high status of their roles, but they often performed tasks without considering the gender implications of their actions. Traditionally, Southern women were responsible for cleaning, cooking, raising their children, maintaining small gardens and producing dairy products, while Southern men primarily worked the land and performed business transactions to sell products and buy agricultural and business supplies. Further, men did possess more legal and political rights than their spouses, though women did maintain some legal protection in this period

${ }^{40}$ Caldwell, "Women in Colonial Georgia" in New Georgia Encyclopedia. Accessed: 09 December 2015, 1. 
as well. ${ }^{41}$ In many cases, however, Southern colonial men and women completed responsibilities that were not always prescribed by their spheres because agrarian families could not always abide by social expectations. The sources suggest that the gender roles of both Southern colonial men and women overlapped, allowing both males and females to perform tasks outside their spheres. For example, dairy and laundry days required that everyone, male and female, participated because dairy products needed to be processed quickly, while laundry needed each person's efforts. In the same vein, women worked in the fields and produced crops for the family business alongside other family members when it was necessary. Thus, women's labors were not always designated within the female sphere. They were equal partners in households and identified as someone other than mother and wife.

During the colonial period, women were often semi or fully independent, owning and operating land by themselves or with their husbands. Lee Ann Caldwell argued that women played a huge role in the initial development of colonial Georgia by owning and managing property, and performed important tasks that were not necessarily ascribed to their gender sphere. ${ }^{42} \mathrm{~A}$ document

${ }^{41}$ Caldwell, "Women Landholders of Colonial Georgia," 15.

${ }^{42}$ Lee Ann Caldwell, "Women Landholders of Colonial Georgia" in Forty Years of Diversity: Essays on Colonial Georgia. Eds. Harvey H. Jackson and Phinizy Spalding (Athens: University of Georgia Press, 1984); Lee Ann Caldwell, "New Deal on a New Frontier: European Women Colonists and Trustee Policy, 1733-1752" in the Journal of the Georgia Association of Historians 16 (1995): 106-26; Ann Short Chirhart and Betty Wood. Eds. Georgia Women: Their Lives and Times, Vol. 1 (Athens: University of Georgia Press, 2009); Harold E. Davis, The Fledgling Province: Social and Cultural Life in Colonial Georgia (Chapel Hill: University of North Carolina Press, 1976); Ben Marsh, Georgia's Frontier Women: Female Fortunes in a Southern Colony (Athens: University of Georgia Press, 2007); Betty Wood, Slavery in Colonial Georgia, 1730-1775 (Athens: University of Georgia Press, 1984); Phinizy Spalding. Ed. Women on the 
she reproduced in her book stated 'Every 'Female Heir in Tail', who was unmarried, would have been entitled to one Lot, and consequently have taken from the Garison the Portion of one Soldier."43 Occasionally, colonial women "owned land outright....By the end of the royal period, women had received more than 70,000 town lots" in Georgia." 44 Most females who fell into this category were widows or single, yet this does little to overshadow the fact that they were in very powerful positions during this period. ${ }^{45}$ Finally, there were some women who earned wages as midwives since "aware of the perils of childbirth, the Trustees provided for a pubic midwife as a Trust expense" and "it was the only government position funded for a female..." where they received a salary of "five pounds per year, plus five shillings per 'laying." 46 Positions such as this one elucidate how important women were to the success of most communities, and show their true dynamics. In colonial agrarian culture, women were key providers to their families and performers of duties outside their gender roles, confirming that men and women were very much equals in many aspects of Southern life.

Moving into the nineteenth-century, the Industrial Revolution drastically transformed Northern society, especially gender ideologies and the social dynamics of the family. Most jobs transferred from the home to industrialized

Colonial Frontier: A Study of Frederica and Early Georgia (St. Simons: Fort Frederica Association and National Park Service, 1995).

${ }^{43}$ Caldwell, 35.

${ }^{44}$ Ibid.

${ }^{45}$ Laurel Ulrich, Good Wives; Demos, A Little Commonwealth: Family Life in Plymouth Colony, 19-59.

46 Ibid. 
cities, and often became the province of men. In turn, males relocated their efforts outside the home as sole "providers" of their families, while women and children remained isolated within the domestic realm as "non-contributing" members of the household. Even more, Northern men solidified their social power while also restricting a woman's status by redirecting the responsibilities of both sexes, and highlighting the importance of the male provider ${ }^{47}$ As such, women began to dislike their new positions and felt their efforts were undermined by the new social order. Meanwhile, the people of the South successfully prevented Southern culture from shifting too drastically, and thus preserved much of their social traditions and gender ideologies from previous centuries. Work and family were still very much intertwined in the American South, and male and female social positions remained equal in many respects. ${ }^{48}$ More important, the sources also reveal that Southern females seemed to maintain their continued dominance in the home, as well suggest that their roles continued to be a central part of the survival of the home and family industry.

There is much to be said about the variety of responsibilities available to Southern elite women within the domestic sphere, and how those duties positively influenced their independence and agency. Scholars have repeatedly presented this role as one that was directly utilized for the betterment and support of the slave-holding South, and that this sphere limited elite females in Southern Society. For instance, Fox-Genovese explained that "the household

${ }^{47}$ Cott, $19-63$.

${ }^{48}$ Anne Scott, 1-63; Fox-Genovese, 37-146. 
world of southern women evolved as part of the development of southern slave society." ${ }^{49}$ Though elite females' social performances did generally support the greater goals of Southern society, I would also argue that Southern elite women were not passive contributors to their families and southern ideals, but instead reaped the benefits of their powerful position. Mistresses elevated their social status and maintained social equality by utilizing their given social parameters.

On the contrary, these women understood that they did more than fulfill patriarchal expectations. In many ways, elite Southern women felt their roles, as mother, slave mistress, and domestic overseer, were fundamental parts of their families' successes. Performance and value are intrinsically intertwined in human behavior, and studies have shown that most people accomplish tasks that have multiple meanings for them. The historian Daniel Scott Smith agrees that "individuals have values (attitudes, beliefs, preferences), and these mental orientations cause their behavior. This axiom, as often implicit as explicit, has played a dominant role in much of the history written in recent years." 50 Although mistresses understood that this role was "inherent" to their sex, they did not necessarily perform their duties solely to please their husbands and abide by Southern ideals either. Suzanne Lebsock, in her examination of antebellum elite Virginia women, argued that "a look at the character of the work available to women helps explain why women themselves might have put

\footnotetext{
${ }^{49}$ Fox-Genovese, 65.

${ }^{50}$ Daniel Scott Smith, "Notes on the Measurement of Values" in the Journal of Economic History Vol. 45, No. 2 (1985), pp 213-218.
} 
more stock in housework and child care and less in gainful employment". She continued, "Housework could be frustrating and exhausting, but because it was still productive and not yet divorced from money, it was not as difficult as it has since become for women to believe that their work was important."51

Similarly, feminist historians have tried to "combat the trivialization of housewifery, insisting that housework and childcare are critically important forms of work, and they point out that for most women, participation in the paid labor force is a less than liberating phenomenon." 52 Would Southern women have lost almost all autonomy if they entered the nineteenth-century wage labor force with the stipulations that their work was highly demanding, sexist, limited, and violent at times ${ }^{53}$ They were proud of their perfectly manicured gardens, neatly organized homes, and properly raised children since these things were direct reflections of their proficiencies as women and Southern citizens. For Southern elite women, searching for purpose and solidifying their self-worth and power in Southern society derived from embracing roles such as domestic overseer, mother, and a slave-holding woman. They thus proved their competence to others by successfully fulfilling these responsibilities, which also manipulated the sphere of womanhood and pushed social boundaries.

${ }^{51}$ Suzanne Lebsock, The Free Women of Petersburg: Status and Culture in a Southern Town, 1784-1860 (New York: W.W. Norton \& Company, 1985), 147.

52 Ibid., 148.

${ }^{53}$ Stansell, City of Women; Jeanne Boydston, Home and Work: Housewives, Wages, and the Ideology of Labor in the Early Republic (Oxford: Oxford University Press, 1990), 1-75. 


\section{"Domestic Overseer"}

Without a doubt, the cult of true womanhood enforced an idyllic framework for Southern elite women to follow in the "Old South." From birth, young girls subscribed to patriarchal ideology that dominated Southern culture in areas of their education, the domestic space, popular discourse, and religion. Female education was fairly remedial consisting of reading, writing cursive, acquiring moral lessons, and learning various domestic responsibilities, though some females expanded their education with foreign language and mathematics as well. ${ }^{54}$ In the 1840 s, Ms. Julia L. Northern wrote that "novels give a person fake views of life. And their curiosities are raised they cock forward to enjoy a happy life."55 In the end, most mistresses were taught what and what not to do, what habits to avoid, and how to properly behave throughout their lives.

At home, young women were surrounded by domestic lessons that enforced ideals of virtue and housewifery. The scholar Marli F. Weiner pointed out that "daughters of plantation owners began their working lives...preparing themselves for their adult lives" at home with their mothers. ${ }^{56}$ Young girls were expected to attend school for short periods of time, learn their domestic trade,

\footnotetext{
54 Barbara Welter, "The Cult of True Womanhood: 1820-1860" (1966). ISTOR: American Quarterly 18: Johns Hopkins University Press.

55 "Student Compositions" (1840's) in the Iverson L. Brookes Papers \#3249, Southern Historical Collection, Wilson Library, University of North Carolina at Chapel Hill; Refer to Anna and Sarah Butler Papers (LSU) for exchanges of lessons of virtue and morality as well. ${ }^{56}$ Marli F. Weiner, Mistress and Slaves: Plantation Women in South Carolina, 1830-80 (Chicago: University of Chicago, 1998), 28.
} 
marry at an early age, and fulfill their domestic responsibilities. As a young Southern Belle in antebellum America, Letitia M. Burwell wrote that:

At that period a girl was expected not only to be an ornament to the drawing-room, but to be also equipped for taking charge of an establishment and superintending every detail of domestic employment on a plantation-the weaving, knitting, sewing, etc.-for the comfort of the negro servants to be some day under her care. ${ }^{57}$

The domestic sphere was the perfect opportunity to instruct Southern ladies about this important role for their success as wives and mothers. Did these females truly follow these rules, embody these lessons of virtue, and stay within the framework of womanhood though? Popular newspapers and magazines, such as the Southern Rose Bud and Youth's Gazette also reinforced proper female virtues. For example, the Southern Rose Bud referred to a female child who passed away in 1831 as " peculiarity amiable and engaging; her behavior marked with a delicate sense of propriety, happily mingled with an artless innocence."'58 It was no coincidence that this child embodied the proper qualities that every female should have possessed. Last, religion was yet another tool for Southern society to enforce ideals of elite male aristocracy. A Gospel Messenger writer advised young southern elite women that they should "study of their profession"' to prepare themselves for married life. ${ }^{59}$ Essentially, young girls were expected to attend school for short periods of time, learn their domestic trade, marry at an early age, conform to cultural lessons, and remain within their restricted sphere until death. By the age of fifteen, however, most

\footnotetext{
57 Weiner, 28.

58 Scott, 7.

${ }^{59}$ Weiner, 28.
} 
Southern women entered into adulthood through marriage, took the reins of their domestic duties, and took charge of their personal needs. It was within this world that most of them took pride in dominating their surroundings, and proved to be as equal and competent as Southern men. ${ }^{60}$

While fulfilling their roles to the best of their abilities, many Southern elite women went beyond these remedial tasks because the domestic sphere required them to be more than just quiet and pious housewives. Marli Weiner agreed, "White women were responsible for providing adequate supplies of clothing for everyone on the plantation; they shared responsibility for supplies of food with their husbands. They cared for their families and slaves by tending the sick and teaching religion, morals, and domestic skills." 61 Anne Scott also explained that "the ordinary planter's wife led a very demanding life."62 Sources from this period confirm that many women used their duties to elevate their social position and maintain dominance within this sphere. Lucila Agnes McCorkle, an Alabama mistress, felt the heavy responsibility of her role reflecting that "'At times again, the ambition of having a well conducted house...and keeping the distinct wardrobes in good order this presses on me."63 Leticia Burwell also spoke of the duties a married Southern woman had to perform saying the "'distress on realising for the first time the responsibilities

\footnotetext{
${ }^{60}$ Refer to Figures 1, 2, 3, 4, \& 5 in Appendix.

61 Weiner, 23.

62 Scott, 28.

63Weiner, 42; Sarah Wadley Diary, 18 October 1860 Series 1: Vol 1 (Southern Historical Collection: UNC, Chapel Hill).
} 
devolving upon the mistress of a large plantation."' 64 To these women, domestic tasks echoed their abilities and competence as females, and were more than assigned daily jobs. If mistresses were required to be defined by this sphere, they made sure they fulfilled these tasks to the best of their abilities in order to claim dominance over themselves and their environment. In turn, though house work defined who they were, Southern elite women made sure that they controlled how others perceived them.

As observers of Southern elite women's lives, it should be understood that Southern womanhood was more than just a trivial existence that required multitasking, managing various projects, and supervising family members near and far. Moreover, most Southern women were not dainty and feeble appendages to their families. They were extremely dominant, strong, independent, and powerful women who commanded respect for what they contributed to their households. And, the role of "domestic overseer" challenged gender expectations at times as well. Domestic responsibilities were daunting and sometimes huge burdens for Southern elite women, yet each day they fulfilled their jobs. Often, these tasks took skill, deliberation, organization, and management that most mistresses completed daily. Nancy Bostick stated about her mother, "Mother was a woman of remarkable...intelligence, and had great executive ability, which latter quality was dispensable in the mistress of a large household of children and servants. She gave unceasing care and

${ }^{64}$ Weiner, 25. 
attention to her children, and personally supervised every detail of their education" and "the negroes of the plantation, their food and clothing, care of their infants and the sick, all came under her control."65 Undeniably, these responsibilities were integral contributions to families in numerous ways, and most households would not exist without women's contributions.

Women were often business savvy in their own right, and earned income for their families. Rebecca Latimer, a Georgia mistress, recalled many items that her grandmother made from scratch, but also spoke about her grandmother's soap business in which she provided detergent for her family and sold cleaning agents to others as well. Latimer stated:

My grandmother made all the starch she used, sometimes from whole wheat, oftener from wheat bran Her seven girls, big and little, delighted in dainty white muslin frocks, and laundry work for thirteen in family was always going on, and insistent in that large household. She was a rare soap maker and every pound was prepared at home with diligent care. The meat scraps and bones were utilized and cooked with lye, drained in ash-hoppers. It made perfect soap for domestic uses. Hard soap was prepared for the big house in various ways, tempered with age and used by young and old alike.66

Latimer's grandmother is a perfect example of how Southern women could provide for their families beyond their apportioned sphere. Manufacturing and acquiring clothing was a huge task for women to complete. Attire was extremely important not just physically, but ideologically as well. Obviously, one needs

65 Mrs. N. B. De Saussure, Old Plantation Days: Being Recollections of Southern Life Before the Civil War (New York: Duffield and Company, 1909) in Documenting the American South, 17. ${ }^{66}$ Rebecca Latimer Felton, Country Life in Georgia in the Days of My Youth (Atlanta: Index Printing Company, 1919) in Documenting the American South, 34. 
clothing to survive in inclement weather conditions as well as to present oneself as civilized. Often, an important business venture or marriage arrangement could be ruined by one's physical appearance. In order for planter wives to supply outfits for everyone, they had to procure materials, take inventory of how much to buy and who to supply clothes to, and budget for expenses. Likewise, manufacturing clothing took time, money and only happened once or twice a year because of how time-consuming it was. Natalie Sumter, the wife of a prominent planter, stated, “'I cut out cloths for the Negroes...fixed those for my sons...Had Hampton's coat cut out and pantaloons Adeline is making it."'67 Similarly, Sally McCarty Pleasants, a Virginia planter's wife, claimed that a Southern female's "large family, the immense retinue of slaves who all had to be fed, clothed, nursed, not to mention the incessant and heavy demands of hospitality, made her the real burden-bearer of the community" not her husband. ${ }^{68}$ Most Southern elite females agreed that this responsibility was daunting yet extremely important to their relatives.

Feeding households was the most important responsibility any woman had as a Southern mistress. There were a variety of ways that these females procured food for their families such as trading with others, purchasing items, or growing edibles in their personal gardens. In fact, quite a few women grew gardens that supplied a decent amount of nutrition for families year-round. Ann

\footnotetext{
67 Weiner, 43; Natalie de Delage Sumter Diary (21 July 1840-22 July 1840) in Louisiana and Lower Mississippi Valley Collections, LSU Libraries, Baton Rouge, Louisiana, ${ }^{68}$ Sally McCarty Pleasants, Old Virginia Days and Ways (1838) in Documenting the American South in Documenting the American South, 35.
} 
Butler, who lived on a plantation in North Carolina, expressed her excitement about growing a variety of fruits for her family, stating, "We have had some fine [...] strawberries, rasberries, and yesterday had four or five cantaloupe." ${ }^{69}$ Eliza Person Mitchell's gardening diary, holding 51 entries, demonstrated just how serious she was about providing for her family. She wrote on "May $4^{\text {th }}$ planted out cabbage plants...16 th at night a killing frost, corn, cimbelines cotton, snaps and everything killed."70 Eleanor Douglas claimed to her friend Sally Hall that "I have 42 chickens to feed and nine cows to help with. I made 40 wt of butter last month." ${ }^{71}$ Southern families relied on wives and mothers to ensure everyone ate well and was in good health. Whether they were buying goods in town or growing items in their gardens, this experience gave planter wives the opportunity to be agriculturalists and merchants while providing for their families. Moreover, this source of income was important for the survival of their families every day, but even more when money was scarce and business was down. For example, women's produce alleviated spending money on expensive food items, and allowed households to be almost self-sufficient. Indeed, they

\footnotetext{
${ }^{69}$ Ann Butler to Sarah Butler, "My Dear Daughter" (15 October 1847) in Anna and Sarah Butler Correspondence, Mss. 581, Louisiana and Lower Mississippi Valley Collections, LSU Libraries, Baton Rouge, Louisiana; Thomas Bridgeman, "The Young Gardener's Assistant" (1845) in the Special Collections and Archives Research Center, (Accessed: February 14, 2016) http://scarc.library.oregonstate.edu; The American Gardener's Magazine and Register (1845) in the Special Collections and Archives Research Center. Accessed: February 14, 2016, http://scarc.library.oregonstate.edu; The Family Kitchen Gardener (1847) in the Special Collections and Archives Research Center. Accessed: February 14, 2016, $<$ http://scarc.library.oregonstate.edu>.

${ }^{70}$ Eliza Pearson Mitchel Diary (1834) in the Person Family Papers \#590, Southern Historical Collection, The Wilson Library, University of North Carolina at Chapel Hill.

${ }^{71}$ Weiner, 63; Eleanor Douglas to Sally Hall (1 May 1820) in the Papers of William Baskerville Hamilton, David M. Rubenstein Rare Book \& Manuscript Library, Duke University.
} 
were not just "gardeners" but took on the forms of provider, business woman, and agriculturist.

Hospitality and nobility played massive roles in the social dynamics of the South. At times, hosting families and entertaining guests might have led to the possibility of marriage arrangements, business transactions, or solidifying one's status in Southern society. Even more, entertaining guests, with and without their spouses, afforded women one more opportunity to exercise influence within their culture and among their families. Often, mistresses served as entertainers and hostesses contributing to worldly conversations, promoting various connections between families, and also exercising influence within their homes. Ann Butler recalled to her daughter that "Mr. Proper came down the morning you left and remained with us until Wednesday."72 Rebecca Latimer recalled that "On Sunday grandmother supervised the big Sunday dinner and the girls mounted the riding horses, wore their best dresses, and went to church, and, as was the custom of the time, there was a lot of courting going on when the beaux rode home with the girls they were inclined to marry."73 Throughout Latimer's diary, she recalled her mother and grandmother hosting parties where opportunities for marriage presented themselves and business transactions were made. Eliza Ripley spoke about her fond days of entertaining saying, "All are gone now. Only the sweet memory of them

\footnotetext{
${ }^{72}$ Ann Butler to Sarah Butler, "My Dear Daughter" (13 June 1847) in Anna and Sarah Butler Correspondence, Mss. 581, Louisiana and Lower Mississippi Valley Collections, LSU Libraries, Baton Rouge, Louisiana.

${ }^{73}$ Latimer Felton, 35.
} 
comes to me in my solitary day-dreams." ${ }^{\prime 4}$ Whether providing food and important supplies to their families or fostering important social bonds between guests and families, Southern elite women alleviated the burdens by making sure they held important roles in the household.

Aside from the benefits that women obtained as important members of the family, many also challenged gender expectations in other ways to complete these important tasks. There is a common theme among sources that suggests Southern elite women performed numerous business transactions such as buying clothing and food, funding their children in school, accounting for money, and requesting other items that they needed to complete their daily responsibilities. Clinton said:

Money management was a significant part of the wife's household role, and the plantation mistress generally kept her own books-to account for cash spent for slaves' supplies, to detail expenditures at the local store, and to provide a record of frugality...When ready cash was unavailable on the plantation itself, many mistresses depended on their family network to provide desired goods and to clear debts. ${ }^{75}$

Indeed, many mistresses budgeted their funds for the home in diverse ways, as well as outsourced for supplies when money was low by borrowing provisions from their close friends and families. Numerous account books show that women knew how to tend to the family budget, but also that they went to great lengths to acquire necessities for their families. Most Southern elite females kept account ledgers that traced what they spent, where they allocated their funds,

${ }^{74}$ Eliza Moore Chinn Ripley, Social Life in Old New Orleans: Being Recollections of my Girlhood (New York: D. Appleton and Company, 1910), 206.

${ }^{75}$ Clinton, 31. 
and with whom they did business. ${ }^{76}$ For example, Catherine Smith Stone, a planter's wife in South Carolina, jotted down her transaction with a merchant, "3.00 received from A. Jollenam, Feb 10 1847. 5.54 interest one year."77 Though this is only one instance, Stone's file is filled with many receipts of her business affairs and how active she was in the running of her home. In addition, Sarah Graves' account book recorded anything and everything on her estate, and was an impressive financial record that indicated she was very involved in the business affairs of her family. ${ }^{78}$

Aside from keeping intricate ledgers, they also networked for supplies, spent their money frugally, and stretched funds to supply their households throughout the year. In 1836, a woman wrote to her husband, “'I spent as little as I can. I sometimes spent 75 cts sometimes 50 , but there are so many little extras that it generally comes to a dollar a day."'79 Mary Ann Washington requested, in 1825 , that "if there is any flause cotton in the store please send me 2 spools." ${ }^{\prime 0}$ Ann Bryan performed a business transaction with her sister Susan Washington in 1834 stating, "I am very willing that you should give eight dollars for the dress and at the same time should like it at six equally as well....You can

\footnotetext{
${ }^{76}$ Account Book (1832-1858) in the Caswell County Historical Association Collection \#5401, Southern Historical Collection, The Wilson Library, University of North Carolina at Chapel Hill. 77 "Catherine Stone Business Transaction" (10 February 1847) in Stone Family Papers, Southern Historical Collection, The Wilson Library, University of North Carolina at Chapel Hill. ${ }^{78}$ Sarah Graves Account Book (1836-1843) in the Graves Family Papers \#2716, Southern Historical Collection, The Wilson Library, University of North Carolina at Chapel Hill; Figure 8 in appendix.

${ }^{79}$ Clinton, 31.

80 Mary Ann Washington to Eliza H Washington "Dear Cousin" (27 July 1825), Elizabeth Washington Grist Knox Papers \#4269, Southern Historical Collection, The Wilson Library, University of North Carolina at Chapel Hill.
} 
give as much as four dollars a piece for the two caps....I should be glad if you would have borders and ribbon put on them...Get me six pairs of fine cloth casimere or something of the kind." ${ }^{11}$ Moreover, Ann Butler requested material to make some items for the children saying, "I wish you to get at the lady's in camp strat two little jackets for T.L.J. I will send you the measurement of them around the waist and the length of their arm. Mrs. P says she has a great variety and will make them of any shape you please." 82 On another occasion, Butler asked her daughter to "get a [...] of linen for [...]. I will take the one you sent for pillion cases, the linen for towels you can get any kind you think will suit. I wont give you any more commission until the next letter." 83 Though this was only one of many tasks that required women to cross into the male sphere, elite wives and mothers confirmed they could be businesswomen and financial managers.

Unmarried and widowed females, perhaps more so than their married counterparts, seemed just as capable as any man to manage the family estates. Though scholars seem to represent them as the exception, these women wielded as much power as Southern males through their responsibilities and social freedom, making them just as relevant as married females. No matter their marital status, most of these women maintained power over their families and properties throughout their lives. Mid-century probate records show that

\footnotetext{
${ }^{81}$ Ann W. Bryn to Susan Washington, "My Dear Sister" (2 August 1834), Elizabeth Washington Grist Knox Papers \#4269, Southern Historical Collection, The Wilson Library, University of North Carolina at Chapel Hill.

82 Ann Butler to Sarah Butler, "Dear Sarah" (28 February 1849), Anna and Sarah Butler Correspondence, Mss. 581, Louisiana and Lower Mississippi Valley Collections, LSU Libraries, Baton Rouge, Louisiana.

${ }^{83}$ Ann Butler to Sarah Butler, (28 February 1849).
} 
husbands began designating female spouses as executors of their wills and sometimes gave their wives complete control over estate assets. Suzanne Lebsock's research of feminine agency among antebellum Virginian women addressed the question of whether or not females of the planter class held any type of control within their gender sphere. ${ }^{84}$ According to her investigation, probate records in Virginia indicate that a higher percentage of men appointed their wives as executors and co-executors, giving mistresses the power to control family assets and property. ${ }^{85}$ Though infrequent in previous centuries, this behavior was a progressive leap for nineteenth-century Southern females. She also suggested that these women benefited from the legal changes that occurred within marriages during this period, especially the decree that required all Virginia wives to have a share in any property that was acquired after matrimony. Lebsock noted that "every widow had a right to her dower, that is, one-third if her deceased husband's personal property and the use of one-third of his real estate and slaves....Whenever a man acquired real estate, his wife acquired a dower right in it." ${ }^{\prime 86}$ Even more, Lebsock also noted that these women's separate properties were placed into a personal account away from their husbands' control after marriage. Essentially, their rights were protected, leaving them with a sense of autonomy and stability after their husbands passed.

\footnotetext{
${ }^{84}$ Lebsock, Chapter 2.

${ }^{85}$ Refer to figures $6 \& 7$ in appendix.

${ }^{86}$ Lebsock, 24.
} 
Mary Batemen lived and ran an entire plantation estate with her aunt, two sisters, and four cousins in the antebellum South. Batemen's aunt inherited the land from her husband, and for the entire year of 1856 she used a diary to document the daily life of her family, but also her aunt's very bold and nonnormative behaviors as a widow. Indeed, she took great pride in her family's ability to survive without the assistance of males in the patriarchal South. She noted a business transaction between her and Mr. Roth who "came, and presented his bill-It cleared off this evening." ${ }^{87}$ On June $17^{\text {th }} 1856$, Cousin Margaret "was in Greenville she went to Dr. Finlays...while she went to the court house to cancel a mortgage which has been held for many years by Mr. Cockrane, but which is now all paid off." 88 There were many more activities that these women completed while living on their plantation, which spoke to the variety of obligations available to them and how dominant they were in their roles as members of the elite. Likewise, Bateman's daily reflections show that gender roles were irrelevant to mistresses who embodied the roles of husband AND wife. Similarly, when Catherine Stone became a widow in 1844, she assumed the roles of both mistress and master in order to keep her estate running. Widows did what needed to be done to run their properties, no matter the social implications. ${ }^{89}$ Stone's entire manuscript consists of hundreds of business transitions from her estate, and though she relied on men for some

87 Mary Bateman Diary, (11 February 1856) in Mss. 661, Louisiana and Lower Mississippi Valley Collections, LSU Libraries, Baton Rouge, La, 56.

88 Ibid., (17 June 1856), p. 79.

${ }^{89}$ Refer to figure 10 in appendix. 
favors, she ran the family's economic affairs solely by herself. Most historians would suggest that women like this had more social freedom because they were not legally tied to anyone, yet these females equally contended with the judgments and discriminations of gender norms that their married colleagues dealt with. The point is that they expanded gender boundaries no matter the circumstances.

Widowed, married, and single women of the American South found ways to elevate their social status and foster purpose in their lives by providing for their families and running their households. Indeed, they found autonomy in a sphere that was not meant to emphasize the importance of Southern womanhood. Nonetheless, this was a significant platform to help women grasp onto something greater than themselves and the mundane realities that comprised Southern culture.

\section{Motherhood}

Motherhood was an integral part of a woman's life during this time period. ${ }^{90}$ For a Southern household, more children meant greater chances of multiple heirs surviving as time progressed, which secured the family name and estate. Of course, some scholars have theorized that this role served the needs of the patriarchal South. Still, for mistresses, this identity was much more than just a resource for the man's prerogative. Motherhood seemed to be a powerful and

${ }^{90}$ Clinton, Chapter 3; Scott, Chapters 1 \&2; Faust, Chapter 2; Weiner, 53-71. 
uplifting source of responsibility for many Southern elite women that instilled purpose in their lives and was a reflection of their ability to maintain control and dominance within their sphere.

Rearing children was an extensive job. From birth, mothers clothed, bathed, watched over, instructed, and guided their children in an effort to produce well-mannered, successful, and honorable citizens. As infants, children were most vulnerable to physical harm through accidents or illnesses, which was why they were kept fairly isolated and restrained at a young age. For this, parents chose rooms located at the back houses far removed from the family and their activities, and many parents "considered a nursery to be a strictly utilitarian space."91 Depending on the home, some mothers would also utilize personal slaves to watch over their children. ${ }^{92}$ Yet, even though mammies or house slaves were employed by some families, many planter wives continued to be heavily involved in raising their children and always felt the impact of motherhood.

Once children learned to walk and were aware of their surroundings, they became contributing members of their families. Boys and girls slept in the same rooms as servants, siblings, or their parents, dedicated themselves to the

${ }^{91}$ Karin Calvert, Children in the House: The Material Culture of Early Childhood, 1600-1900 (Boston: Northeastern University Press, 1992), 67.

92 Refer to White, Ar'n't I a Woman? Female Slaves in the Plantation South (New York: Norton \& Company Inc., 1985) 43-65; Fox-Genovese, Roll, Jordan, Roll: The World the Slaves Made (New York: First Vintage Books Edition, 1972), 327-355; Patricia Morton, “'My Ol’ Black Mammy in American Historiography" in Southern Women. Ed. Caroline Matheny Dillman (New York: Hampshire Co., 1988); Clinton, 201-203. 
family home and business, and developed their cognitive skills for future ventures. With this shift, matriarchs continued to be the guiding force in their children's lives. For instance, elite females' continued to shield their youngsters from illnesses as much as possible. Ann Butler expressed to her daughter Anna that "my little Tom has been quite sick since Monday, I have not thoughts of going...He could not walk he had hurt his leg so badly on Monday his fever came on and did not go off." ${ }^{\prime 3}$ In fear of losing her youngest daughter to illness, Ann removed her from school, attesting that "I am very sorry she had to leave school...as long as her health is not good I rather keep her with me."94 No matter the age, mistresses were always cautious about their younger offspring becoming ill or physically hurting themselves.

Meanwhile, women began to instruct their children on important life lessons as they grew older. From the ages of four to eight, youngsters trained with mom—and sometimes dad—-to prepare them for life and proper education. Girls learned almost everything from their mothers regarding cooking, cleaning, organizing the house, preserving goods, producing food items and hosting events, while boys learned about their father's trade and also recognized how important their mother's tasks were to the family. ${ }^{95}$ In some cases, wealthier individuals hired teachers to instruct their children at an early age until they went to school. Ann Butler explained, "I have determined to get

93 Ann Butler to Anne Butler, "My Dear Anne" (4 August 1847), Anna and Sarah Butler Correspondences, Mss. 581, Louisiana and Lower Mississippi Valley Collections, LSU Libraries, Baton Rouge, Louisiana.

${ }^{94}$ Ibid., "Dear Sarah" (28 February 1849), LSU Libraries, Baton Rouge, Louisiana.

${ }^{95}$ Calvert, In the Great House. 
him to teach until we get another...It disturbs me to see [...] learning nothing at their age. ${ }^{\prime 96}$ Aside from learning the trade of their mothers and fathers, children also spent their time in leisure exploring their surroundings. Caroline E. Merrick remembered traveling with her cousin Antoinette stating, "On a clear spring morning more than fifty years ago, Cousin Antoinette and I sat on the front porch of Cottage Hall ready for a ride and waiting for the stable boy to bring up


tell how today was been passed, I have done little or nothing but arrange my room and the contents of my port folio." 98 Children, girls and boys, remained within the domestic sphere until seven or eight, only traveling with their families or occasionally staying with close relatives until they left for school. Mothers, therefore were very active in their children's upbringings and protected them from anything harmful.

As children grew older, mothers would continue to monitor and raise their children from afar. From eight and on, children were sent to schools to learn various academic lessons that would help them later in life. Girls attended female academies and boys went to boarding schools. Yet even with their children away, these women remained a strong guiding force in their children's lives. Many times, students relied heavily on their parents, especially their

\footnotetext{
${ }^{96}$ Ann Butler to Anna Butler, "My Dear Anna" (31 December 1844) in Anna and Sarah Butler Correspondences, Mss. 581, Louisiana and Lower Mississippi Valley Collections, LSU Libraries, Baton Rouge, Louisiana.

${ }^{97}$ Caroline E. Merrick, Old Times in Dixie Land: A Southern Matron's Memories (New York: The Grafton Press, 1901) in Documenting the American South, 11.

98 Nell Irvin Painter, Introduction in Secret Eye: The Journal of Ella Gertrude Clanton Thomas. Ed. Virginia Ingraham Burr (Chapel Hill: UNC Press, 1990), 73.
} 
mothers, for money, traveling, and advice among other things. Ann Butler, was very involved in Anne and Sarah Butler's lives arranging their travels, sending them money, reprimanding them when necessary, and sometimes requesting items from her daughters as well. Likewise, Ann wrote numerous letters to her girls that made sure Anna and Sarah upheld the morals and values they were taught throughout their young lives, but also made sure they were in constant communication with one another. Ann declared, “If I don't hear tomorrow I will give you both a good scold the next time I write." 99 On many occasions, she made clothes for her daughters, allowed them to buy items that they wanted for school, and often secured travel arrangements for Anna and Sarah as well. She stated, "I say he begins to grind on Monday which he hopes to go...he cannot go up for you to come done before that day week but if he does not begin on that day he will go up for you to come down on Sunday next, and he will let me know so that I can have the carriage at Bayou [...] for you." ${ }^{100}$ Ann's dedication to her teenage girls, similar to many other Southern females, illustrates how devoted women were to their roles as mother.

Not only did they feel the reward of being mothers, but these females exercised a great deal of personal agency in this role as well. They understood that taking care of their offspring to ensure they survived through adolescence was an important task. Moreover, women also knew that this duty was an

99 Ann Butler to Anna Butler, "Dear Anna" (8 October 1845), Anna and Sarah Butler Correspondences, Mss. 581, Louisiana and Lower Mississippi Valley Collections, LSU Libraries, Baton Rouge, Louisiana.

100 Ibid., “My Dear Daughter" (15 $5^{\text {th }}$ October 1847), LSU Libraries, Baton Rouge, Louisiana. 
important test on their abilities as females in a patriarchal world that presumed they were capable of very little. If they failed in their responsibilities as mothers, it gave men more reason to oppress them further and take away the duties that elevated their position in the South. Thus, most of these females were diligent in this role by exhibiting supremacy, control, and agency as matriarchs. Mary Ann Knox described the importance of her role as a mother to her brother Rueben in 1829, "I hope we may have wisdom given us from on high to bring him up in the fear and admonition of the Lord. 0 my Brother what a responsible situation is parents in. We have an immortal soul committ to our care and very depends on our precepts and example in forming his mind for future usefulness and for his own happiness." 101

Finally, an interesting piece of evidence that attests to women's important social role was mothers dressing their children like themselves. Males, especially were subject to this interesting practice. Often, boys wore dresses with the same patterns as their mothers for years, until they turned eight or nine years old and then dressed in more masculine attire. Why was it necessary to feminize young males? More important, why did young children, boys and girls, often dress similar to their mothers? According to Karen Calvert's study of male and female gender positions in the nineteenth-century this act instilled dependency between mothers and children and strengthened the

101 Mary Ann to Dr. Rueben Knox "Now, my dear Brother" (4 December 1829) Elizabeth Washington Grist Knox Papers \#4269, Southern Historical Collection, The Wilson Library, University of North Carolina at Chapel Hill. 
bonds between them..$^{102}$ In essence, children were meant to epitomize and mirror their mothers in every way. Thus women held the upper hand among their offspring and families due to the importance of their role. ${ }^{103}$

Southern elite females truly understood the importance of their maternal duties, for in raising and managing the household they also proved themselves as capable as men to handle any responsibility that was given to them. As Southern matriarchs, they maintained independence and control over their families as much as they did over their domestic environment.

\section{The Female Boss}

Finally, numerous sources suggest that planter wives took pride in their homes, often utilizing house slaves to assist them in daily routines. In turn, these females completed their tasks by any means, even inflicting violence on their slaves to ensure the smooth operation of the household. Yet, how did the role of

102 Calvert, Children in the House, 39-55; Refer to figures 23 \& 24 in appendix.

103 Women's power as mothers can be seen in the fertility trends of the nineteenth-century as well. In the antebellum South, procreating was not a negotiation between husband and wife; it was expected of women to conceive, birth, and raise children for the prosperity of their families and Southern society. Yet, studies of birth rates during this period indicate that some of these females regulated when and how often they conceived. Daniel Scott Smith noted that women's power and autonomy increased within the nuclear family during the nineteenthcentury by their ability to physically regulate fertility. Though there is no significant data that highlights this tendency among women in the South, nor writing that speaks to how and why Southern women regulated themselves, I would suggest that this behavior could significantly validate the extreme measures that Southern women employed to control their social positions as mothers and elite women. Moreover, there is something to be said about holding the power of repopulating any society; Daniel Scott Smith, "Family Limitation, Sexual Control, and Domestic Feminism in Victorian America" JSTOR: Feminist Studies, Vol. 1, No. 3/4, Special Double Issue: Women's History (1973), pp. 40-57; Refer to Figure 18 in appendix. 
slave mistress allow Southern elite women to grasp power over their environment but also prove their worth as females? ${ }^{104}$

As seen from other portions of this chapter, women's responsibilities within the Southern home could be detailed, expansive, and overwhelming at times. Thavolia Glymph agreed, "a mistress meant order and efficiency: clean linen; polished furniture; timely meals; and an end generally to the disorder, sloth, and filth that governed his home without one."105 Lucilla McCorkle realized that "'my domestic cares engross my mind to the exclusion of all religious and social duties."'106 She and many other elite women of the South knew it took hard work to run an entire estate and that the labor within the house was an integral part of the prosperity of the home. ${ }^{107}$ McCorkle hoped that “'may I see and know those things which will render me an efficient and systematic housekeeper"' since her family relied upon her abilities as a provider. ${ }^{108}$

104 Thavolia Glymph, Out of the House of Bondage: The Transformation of the Plantation Household (Cambridge: Cambridge University Press, 2008); Donnie D. Bellamy and Diane E. Walker, "Slaveholding in Antebellum Augusta and Richmond County, Georgia" in JSTOR, 15479.

105 Glymph, 63; Caroline Olivia Laurens Diary (1823-1827) in the Caroline Olivia Laurens Diary \#3483-z, Southern Historical Collection, The Wilson Library, University of North Carolina at Chapel Hill; Juliana Margaret Courtney Conner Diary (1827) in the Juliana Margaret Courtney Conner Diary \#174-z, Southern Historical Collection, The Wilson Library, University of North Carolina at Chapel Hill; Mrs. Issac Hilliard Diary (1849-1860) in Mrs. Isaac H. Hilliard Diary, Mss. 178, 762, Louisiana and Lower Mississippi Valley Collections, LSU Libraries, Baton Rouge, La.

106 Weiner, 24.

107 Ibid., 4, 5, 7, 12, \& 33.

108 Ibid., 24; 
Yet, no matter how difficult things could get, mistresses were content with their position when, on their watch, things ran smoothly and were perfectly completed. At the end of a long week, Catherine Edmondson was impressed with herself because "'my house is in order and my handmaidens wait upon me."'109 Gertrude Thomas wrote in her diary, "how domesticated I am." 110 McCorkle spoke about how she managed her slaves stating, "It is no easy task to control servants and superintend matters with an eye to every thing."'111 Moreover, a woman gave advice to her niece about how to regulate her home saying, “'To be the wife of a rice-planter...is a great opportunity, a great education. To train others...requires method, power of organization, grasp of detail, perception of character."'112 And, Mary Batemen, when speaking about illness in the family, was relieved after reorganizing her family's medicine supplies. She wrote, "new medicine, and had the case scrubbed out. And put them all away."113 Because Southern elite women were consistently being scrutinized they felt pleased when things were completed to their satisfaction.

To help mistresses, house slaves performed tasks that ranged from childcare, cleaning, cooking, or even assisting Southern elite women with other responsibilities that were vital to the plantation's daily operations. In order to ensure that things ran smoothly, many Southern elite women performed their

\footnotetext{
109 Glymph, 63.

110 Virginia Ingraham Burr. Ed. The Secret Eye: The Journal of Ella Gertrude Clanton Thomas, 1848-1889 (Chapel Hill: The University of North Carolina Press, 1990), 145.

111 Weiner, 24.

112 Ibid.

113 Mary Batemen Diary, (19 May 1856).
} 
duties with alacrity, often inflicting harsh physical and emotional discipline on their slaves to ensure that no duty was left undone and their power was unchallenged. To this end, house slaves suffered immensely and were punished severely if their mistresses were not satisfied with the work. The "cowhide" whip, an instrument that was typically three feet long and made from dried ox hide designed to cut flesh and draw blood, was mistresses' favorite weapon when punishing their slaves, though some employed their hands, shovels, or anything else that was at hand. ${ }^{114}$ The fact that whips and other implements went almost everywhere with these women indicates to what lengths they went to rule the household, since if domestic affairs were not satisfied to certain expectations, it reflected badly on the elite woman's reputation.

Ada Bacot wrote in her diary that "'I had the most unpleasant duty to perform...I had to go this morning and see them punished....I knew if I let it pass I would have more trouble."'115 Keziah Goodwyn Hopkins Brevard spoke constantly about the importance of keeping her slaves in line stating, "I have slaves under my care...I have a few terrible spirits to keep in order" and "just as they impudent as they desire to be, whipping did very little good and good treatment made them think themselves better than white people."116 Delia Garlic's mistress '"pick up a hot iron an' run it all down my arm an' han"” while

${ }^{114}$ Figure 9 in appendix; Glymph, 35.

115 Weiner, 43.

116 John Hammond. Ed., A Plantation Mistress on the Eve of the Civil War: The Diary of Keziah Goodwyn Hopkins Brevard, 1860-1861 (Columbia: University of South Carolina Press, 1993), 52 and 90. 
she completed a task in the house. ${ }^{117}$ Punishment and strict regimen were not just inflicted on adults, but slave children in the great house also suffered this violent discipline as well. Every time the children of Harriet Robinson's mistress misspelled words in their lessons "'she gived me a lick cross' the head for it."'118 Glymph noted that Madison Jefferson "said that his mistress pulled his hair so hard it came out and pinched his ears so hard that they bled", while on other occasions she forced the slave children to abuse one another. Madison proclaimed she had them "'get a basin of water, and scrub each others faces with a corn cob...till they bled under the affliction."'119

Beyond protecting and solidifying their position as Southern mistresses, these displays of violence also indicate that elite females defied gender expectations through their forceful behaviors. Normative society depicted women as pious, well-mannered, and gentle. Glymph noted, "In the enduring story of the Old South, mistresses gently ran households and nurtured their families, black and white."120 Mary Ann Mason's etiquette book perfectly described the conduct of a proper Southern lady stating, “"The eye of a kind but firm mistress is the great inspiration to produce efficiency and regularity in her subordinates."'121 Despite this fantasy, however, other evidence suggests that some women sacrificed propriety and turned to force to uphold their position

\footnotetext{
117 Glymph, 33

118 Ibid., 34

119 Ibid, 35 to 36 .

120 Ibid., 17.

121 Glymph, 84; Isabella Beeton, Beeton's Book of Household Management (New York: S.O. Beeton, 1859).
} 
within their homes, thus moving outside their acceptable gender spheres. Thavolia Glymph confirmed, "Mistresses crossed and re-crossed the South's formally designated gender boundaries...slipping in and out of the costume of the soft, gentle 'southern lady.' In doing so, they acted on their power (as when Malvina's mistress slapped her) and their powerlessness (smiling and simpering before men)."122

Numerous elite females behaved in ways that bordered the line of proper gender ideologies in order to maintain order and control. Despite how often we hear about Southern males' violence toward their slaves, mistresses were equally violent and sometimes more forceful than their husbands. Lucretia Heyward recounted that it was her mistress, not her master, who "'cut my back w'en I don't do to suit her."'123 Thavolia Glymph confirmed that "mistresses are named the more brutal and sadistic" than others in their families as well. ${ }^{124}$ Lucy (Park) Byrd, married to William Byrd II, was extremely brutal toward her slaves. According to scholars, "disciplining" slaves was a private affair because it was a very cruel act that they did not want others to see. Yet, defying the rules of southern womanhood and southern culture, Lucy Byrd tortured her slaves frequently in front of guests. On one occasion, William had no choice but to watch his wife beat their help in front of horrified visitors. According to David Hackett Fisher, “'Lucy Byrd's 'sadistic cruelty,' shocked even her husband, who

122 Glymph, 46.

123 Ibid., 39.

124 Glymph and Fox-Genovese 
was no humanitarian"' and “"by this standard, it was Lucy Byrd's disregard for the thin line that separated respectable and disreputable female behavior that brought disapproval, not the beatings per se."'125 Indeed, she was "determined to show her authority before company."126 Based on the evidence of Lucy's violent tendencies, her behavior matched some of the cruelest slave owners in the South, and often mirrored other women's outbursts.

Delphine LaLaurie, a wealthy nineteenth-century New Orleans socialite, employed quite a few slaves in her city home. ${ }^{127}$ While doing so, LaLaurie acted out against her servants in ways that personified her as a "monster" and not a woman of true Southern decorum. In 1834, a fire broke out in her New Orleans home caused by their seventy-year-old house slave who tried committing suicide in fear of being punished and killed for something she did wrong earlier in the day. In an attempt to save EVERYONE in the house, officials and bystanders entered the slave quarters and found "seven slaves, more or less horribly mutilated...suspended by the neck, with their limbs apparently stretched and torn from one extremity to the other."128 The New Orleans Bee depicted LaLaurie as a monster stating, "These slaves were the property of the demon, in the shape of a woman whom we mentioned in the beginning of this

125 Glymph, 47.

126 Ibid.

127 Victoria Cosner Love and Lorelei Shannon, Mad Madame Lalaurie: New Orleans Most Famous Murderess Revealed (Charleston: The History Press, 2011); Carolyn Morrow Long, Madame Lalaurie, Mistress of the Haunted House (Gainesville: University Press of Florida, 2012).

${ }^{128}$ New Orleans Bee, "The Conflagration at the House Occupied by the Woman Lalaurie." April 11, 1834. 
article. They had been confined by her for several months in a situation from which they had thus providentially been rescued, and had been merely kept in existence to prolong their sufferings." ${ }^{129}$ In Mrs. LaLaurie's case, there could have been many reasons why she did what she did, such as punishing slaves over her husband's infidelity or to preserve her power in the LaLaurie family. Nonetheless, these actions clearly demonstrate her defiance of gender conventions, and the great power she held in New Orleans. LaLaurie and even Byrd, confirmed that some women exercised greater power in and out of the home than historians have depicted.

The mistress' violence in the domestic sphere indicates something more than just punishing slaves. This behavior upheld a line of dominance and hierarchy that allowed Southern elite women to set themselves apart from their husbands in ways that positively benefitted their gender position in the South. Governing slaves "gave mistresses the power to be hard and cruel in punishing and humiliating slaves, and the prerogative to be indifferent." To this end "white women's agency has been profoundly underestimated" since "slaveholding women had become, in fact if not in law, central partners in slavery's maintenance and management, more solidly members of the ruling class in their own right despite whatever civil and social disabilities they suffered because they were not men." 130 Though African-American slaves believed the greatest

${ }^{129}$ New Orleans Bee, (April 11, 1834).

130 Glymph, 40 and 31; Stephen C. Crawford, "Punishments and Rewards"; Charles Kahn, "An Agency Theory Approach to Slave Punishment and Rewards" in The Rise and Fall of American Slavery: Without Consent or Contrast Eds. Robert Fogel and L. Engerman (New York: W. W. Norton, 1989). 
power in the plantation household "wore a white male face," it was clear that "the antebellum South was a place where power could wear a "white female face" as well. ${ }^{131}$

\section{Overall Conclusions}

The cult of Southern womanhood was much more than just a tool utilized by Southern males to enforce gender norms. Southern women gained power, independence, and agency within the sphere of womanhood by sustaining their position and influence through performances such as domestic overseer, slave mistress, and mother in the household. Moving outside the home, chapter two centers on the public activities of Southern elite women, emphasizing their desire to help the underprivileged in the American South, while also expanding their roles through social activism.

131 Fox-Genovese, 191; Glymph, 62. 
CHAPTER TWO

AGENCY IN PUBLIC ACTIVISM:

SOUTHERN ELITE WOMEN IN THE PUBLIC SPHERE 
Joining reform movements was common among elite and middle-class women of the nineteenth-century. In the North, there were many organizations that fought for, among other things, higher education, orphaned children, the imprisoned, and prohibition. As common as it was for Northerners to fight for social justice, Southern elite women also invested their time in this same way. Undeniably, mistresses of the South fought for underprivileged citizens in a world that marginalized the poor, African American slaves, and orphaned children. Through their efforts, many elite Southern females challenged acceptable and unacceptable gender roles, but also discovered purpose, freedom, and new political and social "voices" as advocates for ostracized groups.

For the most part, the scholarship about Southern elite women analyzes topics such as their daily lives, their treatment of slaves, and gender dynamics in the household. As a result, their social experiences are regularly considered around the theme of "male domination."132 Though these investigations are extremely important for numerous reasons, most of them fail to acknowledge Southern women's fight for social equality and their quest to create a feminine identity. Presently, only Anne Scott, Elizabeth Varon, and Suzanne Lebsock discuss feminine agency in the antebellum period. Varon argued that Virginia women pushed gender boundaries through their involvement in the political and public arenas, and that Southern elite women were much more powerful

${ }^{132}$ Refer to historiography in the Introduction. 
than previously believed. She concluded, however, that these actions defended the culture that oppressed them in the first place. On the contrary, Lebsock and Scott claimed that women's pubic involvement and their efforts within the domestic sphere were indicative of feminist ideals and not necessarily a defense of patriarchy. The largest drawbacks of both scholarships, however, are that Lebsock's work is too limited in scope and Scott's research in the antebellum period requires more evidence. Not only do I reference all three of these scholars' works in this chapter, I apply their research to women who lived throughout the South and who lived in different time periods. We will see that these females went beyond their roles as mothers and wives, and participated in social causes separate from domestic responsibilities not just to fight for others' rights but to expand their own as well.

\section{Background}

Many Southern elite women challenged society's normative expectations in various ways, and one of the most positive impacts on women's social position in the South was public activism. They formed a sisterhood between each other as they fought for common social causes, realized their potential in the political and economic arenas, and established a purpose outside their designated sphere. In this world, they did not confine themselves to the home or identify as wife or mother. They were powerful social activists adhering only to their own expectations and fulfilling their own personal goals. According to expectations, these females were taught to be modest, even-tempered, and 
virtuous in private and public spaces. According to Savannah Sheppard, a school girl in North Carolina, modesty "is a polite accomplishment generally attendant to those who are in the highest degree engaging and [...] the heart of all with whom they are acquainted...Modesty is a peculiar ornament to the female soul whether old or young." 133 While she also wrote that pride "of the word is inordinate self-esteem, loftiness, of air, elevation, orientation. Pride is of two kinds, one is very good in its place [...] is necessary for us to have enough pride to be decent but we should not have [...] as to esteem ourselves higher than others." ${ }^{134}$ Ideas, such as the ones above, were engrained into women through various modes of popular discourse in order to mold them into subservient females.

Aside from the inner qualities that a woman should have possessed, mistresses' roles were strictly regulated to the domestic sphere, and popular discourse emphasized that they were required to give complete devotion to their families. ${ }^{135}$ However, despite how regulated they were "supposed" to be, sources reveal that many Southern elite females went outside the home to engage in various social causes, while some of them abandoned their roles completely to fulfill their needs as independent activists. What does this trend emphasize? As women grew older and understood that some expectations were unattainable, their perceptions of Southern womanhood changed and they

\footnotetext{
133 Iverson Papers, "Student Compositions" (UNC: Southern Historical Center) ${ }^{134}$ Ibid.

135 The Southern Rose and The Southern Lady.
} 
disregarded numerous gender ideals to pursue lifestyles that were more conducive to their necessities and goals. Many of them felt they were needed to address issues of poverty, illness, homelessness, and slavery in the South, attacking these issues through political, social, and economic measures.

Southern elite mistresses volunteered to work for movements such as the Female Humane Association, Union Benevolent Society, Female Charity School, Female Orphan Asylum, Female Free School, Temperance Society, American Colonization Society, Second Whig Party, and Sectional Mediators. In fact, some Southern elite women developed and ran auxiliary organizations to support these causes, but also did so when male-operated groups abandoned their efforts to help others.

\section{The Female Orphan Asylum, The American Colonization Society, and Others}

The Female Orphan Asylum, established in 1838 in Petersburg, Virginia, was developed out of the necessity to deal with the influx of homeless females in the Southern states. This organization and its auxiliaries clothed, fed, sheltered, and educated women who were impoverished or abandoned by their families at young ages, often placing these girls in foster homes until they were eighteen years old. ${ }^{136}$ Elite Southern women felt that "orphaned girls, in short, were sexually endangered, intellectually disadvantaged, and economically vulnerablemore so than orphaned boys" thus it was imperative to protect them from harm

136 Varon, 366. 
and educate them to become productive citizens. ${ }^{137}$ Indeed, these institutions tried to prevent young abandoned girls from entering into a "fast path to prostitution". ${ }^{138}$ Southern elite women sought to correct the vices associated with poverty and assumed any burden to accomplish the task, even at the risk of challenging normative gender expectations in their society. Though it was not necessarily expected of Southern women to help others outside their families, their actions often contested acceptable social behaviors in the South, demonstrated to mistresses their capabilities in many areas, and showed them that equal opportunity belonged to all.

Southern women were heavily involved in the inner workings of this group in many different ways including lobbying for certain rights, soliciting support from others, and raising funds. Within this organization, many women even performed responsibilities that were not necessarily associated with their proper social sphere. According to Elizabeth Varon, some of the most prominent people within this group were talented and accomplished women such as Jane Taylor, Mildred Campbell, and Mary Cummings, whose work was some of the most extensive, important, and progressive in this organization's history. ${ }^{139}$ Married to a prominent attorney, Jane Taylor spent many years advocating for this organization, and according to historian Edward A. Wyatt she maintained a very tumultuous and controversial career in teaching after she became a

\footnotetext{
${ }^{137}$ Lebsock, 205.

138 Ibid., 204.

139 Ibid., 206.
} 
widow. ${ }^{140}$ Not only was she intelligent, but she was dedicated to her public responsibilities, including her time with the Female Orphan Asylum. A minister wrote of her personality that she was '“a lady of genius and information."' While Mary Cummings noted of her friend that "'Often before I had the pleasure of knowing this lady I had heard of her...I thought I should feel she came to see me, I found her lively, cheerful, and agreeable."'141 Mildred Campbell was an important figure in the success of this asylum as well. She lobbied for certain legal rights for the group, wrote and signed petitions, and performed other tasks that were vital to the Female Orphan Society's success. One citizen noted that her husband "was not more esteemed for learning and scholarship than was his accomplished lady", and Edmund Ruffin, a wealthy Virginia slave owner and friend of Campbell's, wrote that "her mind is masculine."142

One huge undertaking of the Female Orphan Asylum was its goal to seize complete control over assets that some orphaned girls possessed at the time they were taken into the organization. According to Lebsock, forty-six women signed an incorporation petition to obtain power over the funds of certain orphaned females and guardianship of their students until they were adults. ${ }^{143}$ Normally, girls were legally bound to their fathers, other male relatives, or wards-of-the-state until they turned eighteen or were married. Yet, these petitioners undermined male authority in public and political arenas by taking

140 Lebsock, 206; Edward A. Wyatt, "George Keith Taylor, 1769-1815, Virginia Federalist and Humanitarian", (1936) in the William and Mary Quarterly 16: pp. 2-18.

141 Lebsock, 206-207.

142 Ibid, 206-209.

143 Ibid. 
away their legal power over orphans. An 1812 newspaper documented these women's appeal to the people of Petersburg for further assistance in establishing this institution, saying, "There is no doubt but the institution will be carried into effect, and it is hoped that those who have not yet contributed...come forward."144 Similarly, many Southern elite women worked as office managers, educators, and guardians to aid their students as well. While others opened up auxiliaries across the South and fully-ran their institutions with all-female boards. At one point the Female Orphan Asylum "hired a matron to supervise the school" which was highly unusual in the first half of the nineteenth-century in many southern organizations. ${ }^{145}$ There are numerous lessons to be learned from the actions of FOA female members. One, their actions challenged male authority in countless ways in an effort to solve the issue of poverty. Two, as these women became more involved in political and economic ventures they also blurred the lines between acceptable and unacceptable social behaviors among males and females. Three, Southern elite women's efforts to educate and prepare young girls for adulthood could also be seen as an attempt to give equal opportunity to girls later in life.

These trends can also be identified in other orphan asylums across the southern United States as well. ${ }^{146}$ One group, in particular, epitomized the

${ }^{144}$ Intelligencer, (13 March 1812) in Valentine M. Mason Library, Lexington, Va.

145 Lebsock, 174.

146 Alabama Mobile Catholic Orphanage Asylum, Alabama Mobile Protestant Orphanage Asylum Society, Georgia Augusta Orphan Asylum, Georgia Columbus Ladies' Education and Benevolent Society, Georgia Darien McIntosh Female Asylum, Georgia Macon Orphan Asylum, Georgia Muscogee County Muscogee Asylum, Savannah Female Asylum, Georgia Sunbury Female Asylum, Kentucky Louisville Orphan asylum, Louisiana New Orleans Female Orphan 
intelligence and power of female initiative. The Savannah Female Asylum's organization, founded in 1801, operated along the same structure as the FOA, yet was composed of an all-female executive board. The 1810 minutes from one meeting identified the members by stating, "Mrs. Clay, 1st Directress, Mrs. Noel, 2nd Directress, Mrs. Smith Treasurer, Mrs. Irvine Secretary, Mrs. Wall, Mrs. Evans, Mrs. Stilles, Mrs. Millen, Mrs. Taylor, Mrs. Williamson, Miss. Stephens, Miss. Hills, Miss. Jones." Not only did these members run this auxiliary without much outside assistance, but they held full control over monetary funds, delegated resources to areas of their choosing, and developed social events around their needs as well. In 1811, the Savannah Female Asylum minutes showed that on, "Jan 21, 1811, The board, to a request of Mrs. Achords to give her two children six months education, agreed to give, each of them two quarters schooling."147 The work of the women involved in the Female Orphan Asylum as well as other orphanage societies across the South personified the strength and competence of Southern women. Not only did their efforts prove useful to the ones they were helping, but elite Southern females were also exposed to the idea that minorities deserved equal opportunity in American society, including their

\footnotetext{
Asylum, Louisiana New Orleans Poydras Female Orphan Society, Maryland Baltimore Female Orphan Asylum, Mississippi Natchez St Mary's Orphan Asylum, Missouri St Louis Orphan Asylum, North Carolina Fayetteville Female Orphan Asylum Society, South Carolina Charleston Orphanage, South Carolina Charleston St Michael's Orphanage, South Carolina South Carolina Orphanage, Tennessee Nashville Protestant Orphan Society, Virginia Fredericksburg Female Orphan Asylum, Virginia Lynchburg Orphan Asylum Society, and Virginia Norfolk Female Orphan Society (Female Charitable Society).

147 "SFA Minutes" (1810-1858) in Savannah Home for Girls Papers \#692, Georgia Historical Society, Savannah, Ga.
} 
own group. According to Nancy Cott, this mentality influenced women to join the first wave of the Feminist Movement in the North.

The American Colonization Society, founded in New York in 1816 by Robert Finley, was an organization that pursued two distinct principles for its members and supporters. For some participants this group provided the means to help African-American slaves, while other members felt it was a way to deport freed servants and bring honor back to their culture. ${ }^{148}$ The coalition consisted of mostly Quakers and Evangelicals, attracting citizens from New York, Vermont, Virginia, Maryland, North Carolina, Georgia, and Kentucky. ${ }^{149}$ Maintaining itself through contributions and membership dues, the funds enabled the group to relocate as many slaves as possible, and sometimes to purchase African-Americans' freedom. By 1819, it became so popular that Congress contributed $\$ 100,000$ toward the group's effort to build the first transport ship.

\footnotetext{
148 John She David, The American Colonization Society: And the Founding of the First African Republic (Bloomington: iUniverse LLC, 2014); Eric Burin, Slavery and the Peculiar Solution: A History of the American Colonization Society: Southern Dissent (Gainesville: University Press of Florida, 2008); Life Membership Certificate for American Colonization Society (1840) in the Certificate American Colonization Society Papers Manuscripts Division, Library of Congress; The African Intelligencer: vol 1, no. 1, in the Rare Book and Special Collections Division, Library of Congress; A Black Colonizationist, Memoir of Captain Paul Cuffee, A Man of Colour: To Which is Subjoined The Epistle of the Society of Sierra Leone in African \& etc (York: W. Alexander, 1812) in the Rare Book and Special Collections Division, Library of Congress; Amos J. Beyan, The American Colonization Society and the Creation of the Liberian State: A Historical Perspective (New York: University Press of America, 1991); Douglas R. Egerton, "'Its Origin Is Not a Little Curious': A New Look at the American Colonization Society" in the Journal of the Early Republic 5, no. 4 (1985), 463-480; Yekutiel Gershoni, Black Colonialism: The Americo-Liberian Scramble for the Hinterland (Boulder: Westview Press, 1985); Varon, 628.

${ }^{149}$ Republic of Liberia. Drawn Under Superintendence of Com. Lynch, USN (1853). Map. Library of Congress: Geography and Map Division.
} 
Indeed, the American Colonization Society became a very popular movement with many different motives. Though men were heavily involved in this organization, elite mistresses were extremely active in it too. Elite Southern females were motivated by moral, personal, and religious sentiments, either wanting to repatriate emancipated slaves for their own families' safety or free slaves for as an act of charity. Beyond women's personal motives, their behaviors often walked the line of social propriety through their fundraising efforts and their greater fight for this foundation. Henry Clay, a huge supporter of the ACS, often praised women's efforts to further the organization's cause when it came to returning slaves to Africa. ${ }^{150}$ According to Clay, "'Our mothers, our wives, and sisters, always foremost in every benevolent and charitable design, are with one heart, and one voice, enlisted in its service"'151 The wives and daughters of slave holders were important to this cause. They contributed much of their time and intellect, and men were quick to acknowledge that women were an integral part to this organization's efforts.

Southern elite women contributed financially to this group, raising funds through events and social connections. According to Elizabeth Varon, countless ACS publications and private papers reveal "abundant evidence of female zeal for colonization....Throughout the 1820s, scores of Virginia women donated time and money to the colonization cause."152 She also attested that "Beginning

150 Varon, 639.

151 Ibid; Henry Clay, "An Address Delivered to the Colonization Society of Kentucky" (Lexington: American Colonization Society, 1829), 19.

152 Varon, 642; Annual Report of the American Colonization Society (1823), <https://books.google.com>. 
in 1825, a number of informal networks of female colonization's proved to be highly effective at soliciting contributions for the cause."153 Mistresses often sold goods and solicited memberships at various places, including county fairs, to raise money for various projects. For instance, the donations of the "Aux. Soc. Jefferson, Co., Va., per Wm.-55.00" and the “Aux. Soc. Fred. Co. Va. Per O. Waite, 150.00 " contributed large investments to the American Colonization Society in 1823, and many other auxiliaries donated their funds to the flag ship organization to continue their efforts as well. ${ }^{154}$ The 1830 Annual acknowledged the efforts of Southern women and stated, "the moral influence of female zeal, exerted in a cause like this, can scarcely, I think, be too highly appreciated....That this society is cheered and encouraged by the favour shown to it by our faircountry-women, and that their generous efforts deserve the most cordial and heartfelt thanks."155

Female members also turned to politics in their effort to emancipate freed slaves. Originally, the ACS was primarily fueled by social and economic motives, yet this group had no choice but to become entangled in political issues as the Civil War approached and sectionalism became a more heated topic in both the North and the South. In the South, members were not necessarily concerned with finding homes for ex-slaves anymore, but instead addressed the

\footnotetext{
153 Varon, 643.

${ }^{154}$ Annual Report of the American Colonization Society (1823) in <archive.org>; Ibid., 1825; Ibid., 1826; Ibid., 1826; Ibid.,1825.

155 The African Repository V. 5 (1830), xi. <http://babel.hathitrust.org>; Lori D. Ginzberg, Women and the Work of Benevolence: Morality, Politics, and Class in the Nineteenth-Century United States (New Haven: Yale University Press, 1990), 45-50.
} 
"plight" of freed slaves. In addition, numerous slave holders, such as Henry Clay, felt some members of this association reinforced the power of the federal government instead of focusing on repatriating emancipated slaves to make the Southern U.S. "safer" for their people. Furthermore, many Southerners were wary about some Southern elite women going beyond the group's mission, and pushing for emancipation and the education of slaves; southern planters believed that this behavior threatened the South's social, racial, and political stability in the onset of Northern aggression. ${ }^{156}$ Due to these factors, some members of the American Colonization Society tried to separate themselves from the controversy to regain influence and support from Southern citizens by reorganizing as the Virginia Colonization Society (VCS). With these changes, this newly established group refocused on deporting slaves and avoided sectional issues altogether. ${ }^{157}$ More important, however, many female members stayed committed to the cause of the American Colonization Society, which allowed them to remain a central part of this group and sometimes behave in ways that were beyond "appropriate" in Southern culture.

By 1828, the ACS continued its fight by moving to find legislative help, not private or local, to relocate more freed slaves. According to Varon, many petitions went out across the South to try and resolve this "pressing" issue, and three, in particular, were produced by Southern elite women. The Female

156 Varon 132; Refer to figure 13 in appendix.

157 Burin, 157; Varon, 679; David, 135; Alison Goodyear Freehling, Drifting Toward Dissolution: The Virginia Slavery Debate of 1831-1832 (Baton Rouge: Louisiana State University Press, 1982), 119-121; P.J Staudenraus, The African Colonization Movement 1816-1865 (New York: Columbia University Press, 1961), 173-178. 
Citizens of the County of Fluvanna drafted the first petition in 1832. This appeal declared that the system of slavery should end and those freed should be sent to Africa immediately because of the turmoil over the question of slavery, the violence that accompanied this system, and the growing population of freed African-Americans that jeopardized the moral and economic integrity of the Southern home. ${ }^{158}$ Mary Blackford's organization, the Falmouth Female Auxiliary, sent a second petition for the gradual emancipation of slaves to reinforce the Fluvanna groups efforts. ${ }^{159}$ Blackford stated the "Female citizens of Fredericksburg"' could "'not refrain in uniting with their sisters from Fluvanna"' and understood that "We would not amid a crowd of selfish considerations, forget the interests of an unfortunate people. We would supplicate for them, from your body, such an attention to their welfare and happiness."'160 Following Blackford's petition, the women of Augusta County produced a third appeal signed by 215 females requesting "for the adoption of some measure for the speedy extirpation of slavery from the Commonwealth."'161 Though not all three petitions made it to the legislature, the point remains that these women entered into the masculine political world of Southern males in order to find support for a growing crisis in the Southern United States.

\footnotetext{
158 Varon, 11-41.

${ }^{159}$ Refer to figure 14 in appendix.

160 Varon, 723.

161 Ibid., 732.
} 
The American Colonization Society was the perfect platform for women to operate outside their gender sphere. They performed tasks as social and political lobbyists, they were heavily involved in the economic functions of the group, and they were public figures in a crusade for the protection of what they thought were in the best interests of Southern culture and freed slaves. Without them, this organization would not have been the success it was, and without this environment, women might have remained oppressed within their own sphere.

Aside from the Female Orphan Asylum and the American Colonization Society there were other charitable groups that sprung up in the antebellum South. Yet, because they left few sources it is difficult to tell how they operated and what they did. We do know that a majority of them, until the 1850 s, were operated and controlled by Southern elite women, and that ending poverty, promoting religion, and supporting education were some of the main concerns of these smaller groups. For example, the Presbyterian Church of Virginia established the Female Bible Society, Married Ladies Missionary Society, Young Ladies Missionary Society, House of Industry, Education Society, and the Orphans' Society to combat various issues in the South during the nineteenthcentury. ${ }^{162}$

Within these groups Southern elite women sustained themselves through their business and social efforts, and according to records these

162 Varon, 370; "A Brief History of the Presbyterian Church, in Petersburg" (Petersburg: Yancey \& Wilson, 1833), 48-49; figure 15 in appendix; Lebsock, 218. 
organizations made "a great deal of money" at state fairs and other events.

Frequently, they acquired funds through memberships, outside donations, and selling homemade goods to people. For instance, a social activist named Ann Davis noted how proficient she was at marketing her products stating:

Alice undertook to sell a boquet for me the other night, and she got for it $\$ 2.01$. She at first sold it for 50 cites, and it was given back to her; she sold it a second time for the same price, and it was again given to her...afterward met with a spry old widower, who seemed to be much taken with her, he told her that he would give her for it all the money he had left in his purse, which amounted to $\$ 1.01 .163$

For Davis, it seemed clear that profit was just as important as what those funds were allocated for. Aside from selling goods, these women worked tirelessly to make those products for purchase as well, often making them months or weeks in advance. Susan Bott explained, “I am induced by YR former obliging readiness, to work for the Ed. Society to request yr assistance in helping us to prepare for our annual meeting."'164 Not only did women produce and sell items for their societies' revenues, but they also invested these profits in certain areas as well. The minutes of the Dorcas Society of the First Baptist church show that “The subject of disbursements coming next in order, the ladies were unanimously agreed, after deliberating; that the sum of 5.00 should be sent to Mrs. Holloway as a donation..."'165 Likewise, the females of the Petersburg Presbyterian's Education Society decided to allocate money to “menstrual

${ }^{163}$ Lebsock, 219; Ann T. Davis to [?] Davis (25 May 1860) in the Beale and Davis Family Papers \#2572, Southern Historical Collection, The Wilson Library, University of North Carolina at Chapel Hill.

${ }^{164}$ Ibid., 218.

165 Ibid., 221; First Baptist Church (Washington Street), "Dorcas Society Minutes" (6 October 1856). 
candidates of their own choosing."'166 Though these smaller organizations left only fragments of evidence, they do show Southern elite women's dominance, independence, and power among these social groups.

Women's efforts within these organizations illustrate that Southern elite women were very much involved in spheres outside the home, they performed duties not necessarily associated with their sex, and they secured their social position among Southern society. Yet, what about the women who utilized more radical measures to fight for social justice?

\section{The Radicals}

Though most southern women fought for social justice through more conservative measures, there were a few women who utilized more drastic means to fight for peoples' civil freedoms. This final section highlights a few of these females, whose goals were much more extreme than others who battled for social justice in the South, and whose actions drastically defied expectations.

Two of the best known, yet rare, examples of defiant Southern women were Sarah Moore Grimke and Angelina Emily Grimke, both famous abolitionists and feminists of the nineteenth-century. 167 Born into an elite plantation family in South Carolina, both sisters witnessed slavery and male

166 Varon, 222; Abraham Brooks Van Zandt, "The Elect Lady": A Memoir of Mrs. Susan Catherine Bott (Charleston: Nabu Press, 2011), 102-03; Bristol Parish Vestry Book (17 June 1840) in $<$ archive.org>.

${ }^{167}$ Refer to figure 16 in appendix. 
supremacy in one of the biggest populations of slave holders in the South. Yet, both girls refused to conform to Southern ideals on gender expectations and slavery, often protesting in different ways. Out of the two sisters, Sarah was the most confident and forceful in her opinions about human bondage and women's rights. A tragic event in her early life inspired her to gradually abandon Southern culture by the time she was an adult. After seeing a slave beaten at home, a four-year-old Sarah tried boarding a train to find a place where slavery did not exist, though she was unsuccessful. A few years later, she began teaching her personal slave to read, and in the process broke the law. ${ }^{168}$ Indeed, Sarah was completely against this system from a very young age, and this speaks volumes as to how intelligent and observant she was her entire life. She stated, "after being for many months in Pennsylvania when I went back it seemed as if the sight of [the slaves'] condition was insupportable...can compare my feeling only with a canker incessantly gnawing...I was as one in bonds looking on their sufferings I could not soothe or lessen."169

Sarah also fought for the equality of females in the United States alongside Susan B. Anthony, Elizabeth Cady Stanton, and Lucretia Mott among other women. Some scholars would argue that her passion for women's social equality stemmed from her own desire, as a child, to earn an education equal to males. As a young girl she dreamed of being a lawyer and

168 Mark E. Perry, Lift Up Thy Voice: The Grimke Family's Journey from Slaveholders to Civil Rights Leaders (New York: Viking Penguin, 2002), 2; Catherin H. Birney, The Grimke Sisters (Whitefish: Kessinger Publishing, 2004).

${ }^{169}$ Sarah Grimke, <http://www.nps.gov/wori/learn/historyculture/grimke-sisters.htm>. 
studied many of her father's books on history, mathematics and geography, though he did not allow her to learn beyond what she absorbed in the library nor did he allow her to attend college. Sarah Grimke wrote “ “...the powers of my mind have never been allowed expansion; in childhood they were repressed by the false idea that a girl need not have the education I coveted."'170 Growing up in the patriarchal South, Sarah was often prohibited from partaking in many things she wished to do as a Southern female. She wrote, "They had incurred the penalty of sin, they were shorn of their innocence, but they stood on the same platform side by side, acknowledging no superior but their God." ${ }^{171}$ By 1835, at age 43, Sarah Grimke became an avid abolitionist and feminist, moving North and working tirelessly for numerous causes.

Following in her sister's footsteps, Angelina spoke publicly about her opposition to female oppression and slavery as well, writing letters to important figures and publishing her work in the Liberator, an abolitionist newspaper. She wrote, "If persecution is the means which God has ordained for the accomplishment of this great end, emancipation, then....I feel as if I could say, let it come; for it is my deep, solemn deliberate conviction, that this is a cause worth dying for." ${ }^{172}$ Moreover, Angelina published her work An Appeal to the Christian Women of the South in which she spoke to Southern women about

170 Scott, 64; Sarah Grimké to Harriot Hunt [31 December 1852] in Weld-Grimké Family Papers, William L. Clements Library, The University of Michigan.

${ }^{171}$ Sarah Moore Grimke, Letters on the Equality of the Sexes, and the Condition of Women: Addressed to Mary S. Parker, President of the Boston Female Anti-Slavery Society (Boston I: Knapp, 1838), 3 via <archive.org>.

172 The Liberator [17 February, 1851] via <fair_use.org>. 
how important their efforts were in abolishing slavery everywhere. She stated, "Be not afraid then to read my appeal; it is not written in the heat of passion or prejudice, but in that solemn calmness which is the result of conviction and duty. It is true, I am going to tell you unwelcome truths, but I mean to speak those truths in love, and remember"173 Finally, both sisters, in 1839, were co-editors on the book American Slavery As It Is: Testimony of a Thousand Witnesses, which printed stories concerning the atrocities of Slavery. ${ }^{174}$ This work was extremely influential for its time and reached people all around the United States. Throughout their lives, both sisters worked alongside powerful people such as William Lloyd Garrison and Elizabeth Cady Stanton to fight for women's rights and the freedom of African-American slaves. Even more, Sarah and Angelina embodied nonnormative ideals and behaviors that showed how Southern elite females resisted the social expectations of the nineteenth-century.

Anne Rice, one of the most prominent supporters of the ACS, dedicated many years to this organization, and performed tasks that defied Southern cultural expectations. Mary Virginia Terhune wrote of her aunt that she was “'the leader in a crusade that would wipe the stain of slavery from her beloved state."'175 Rice was an adamant abolitionist for the sake of bringing honor back to her culture. In 1848, she freed one of her beloved slaves and sent him back to

${ }^{173}$ Angelina Moore Grimke, Appeal to Christian Women of the South (New York: American AntiSlavery Society, 1836) via <archive.org>, 2.

174 Grimke Sisters, American Slavery As It Is: Testimony of A Thousand Witnesses (New York: American Slavery Society, 1839) via Documenting the American South.

175 Varon, 657. 
his home in Africa in hopes that this would influence other Southerners to do the same. ${ }^{176}$ For this time period, Rice's actions went against everything that her culture stood for, including allowing a woman to free a slave. Louisa Cocke, another important woman involved in the ACS, donated countless amounts of money and time to her organizations during the 1820 s and 1830 s. ${ }^{177}$ Finally, Ann R. Page, a resident of Virginia, attacked the "evil power of slavery"' and was destined “ "...to a great missionary work in her own country, and at her own home."' She felt that '“we are especially tempted to make the poor subservient to our own indulgence when those poor are our bond slaves and we can do as we like with them, and hush their murmurs by authority or by selling them."'178 Yet, there was no greater act that Page could have performed than when she "sent an estimated twenty-three manumitted slaves to the colony." 179 Although Page was "discouraged by her neighbors' disapproval of her efforts" she felt 'the cause has for so many years been the chief object of my heart and life" and "that I require one, who sees it in the light you do, to bear with me."180

Finally, Mary Berkeley Minor Blackford's efforts in the abolition of slavery, most notably her development of the Falmouth Female Auxiliary, were some of the most drastic and important deeds in ACS history. ${ }^{181}$ According to

\footnotetext{
176 Varon, 648-57.

177 Varon, 410 and 659; Louisa Maxwell Holmes Cocke Diaries (1816-1843) in Albert and Shirley Small Special Collections, Charlottesville, Va.

178 Varon, 659.

179 Ibid, 668; Bell Irvin Wiley, Slaves No More: Letters from Liberia, 1833-1869 (Knoxville: University Press of Kentucky, 1980).

180 Varon, 674.

181 Ibid. Refer to Mary Blackford's draft of an address to the ACS in the Papers of Launcelot Minor Blackford (1829) in Albert and Shirley Small Special Collections, Charlottesville, Va.
} 
Varon, Blackford's cohort included Dolley Madison (wife of James Madison) and Catherine Lomax (Female Orphan Asylum Director). ${ }^{182}$ Their efforts included supporting other auxiliary groups in the South, speaking with Virginia citizens in numerous counties, drafting and signing political petitions, pushing male figures to continue their support, and lobbying in countless areas for members and funds. Even more, Blackford's petition, which supported the Fluvanna organization's legal requests and was signed by her and eighteen members in 1820 , was a very power testament to women's capabilities in the South. Equally, her group earned countless amounts of funding throughout their existence, raising $\$ 500$ just in the year of 1820.183 Blackford's labors were hailed as “'The example too of the Females of every great people, from the virtuous wife of Coriolanus to our own Revolutionary Matrons teach us that in times of great interest to their Country, women may come forward, meekly and humbly..."'184 She understood that many Virginians felt her and other social activists' actions were intrusive "into a subject we have no business to meddle with"' though these comments did not deter their efforts. ${ }^{185}$ Yet, Blackford, herself, addressed the people who believed Southern elite women should not be involved in political measures saying, "'We would ask whether...our sex is to be forever precluded from any agency in its promotion?"'186 After 1832, Blackford's

\footnotetext{
182 Varon, 674.

183 Ibid., 669; Launcelot Minor Blackford, Mine Eyes Have Seen the Glory: The Story of a Virginia Lady, Mary Berkeley Minor Blackford (1802-1896), Who Taught Her Sons to Hate Slavery and Love the Union (Cambridge: Harvard University Press, 1954).

184 Varon, 727; A Share of Honour: Virginia Women, 1600-1945 (Richmond: Virginia Women's Cultural History Project, 1984), 77.

185 Varon, 693.

186 Varon, 781.
} 
organization along with other proxy groups continued to rise until the start of the Civil War.

The countless efforts of the Grimke sisters, Blackford, Page, and other radical women make clear that they crossed gender boundaries to fight for the rights of others and themselves. These women were some of the most important crusaders of the period, whose fearlessness resonated with women who witnessed their strength, independence, and control. Though they were not the majority, their willingness to defy cultural norms for their causes suggests that some women, even if only a few, challenged the Southern way of life.

\section{Conclusion}

We have seen, through these social organizations that Southern elite women were much more powerful than most research credits them for. Despite the odds, Southern mistresses entered the public sphere in a world that tried, very hard, to regulate their every move. Further, I would suggest that the women who ventured into this arena paved the way for others to work outside the home and discover autonomy and agency from their competencies. The final chapter expands on the topic of autonomy, and examines how southern sisterhood convinced elite women to create a sense of community over their shared oppression. 


\section{CHAPTER THREE}

\section{A WORLD OF THEIR OWN: \\ AGENCY WITHIN THE SOUTHERN FEMININE COMMUNITY}

“An analysis of women's private letters and diaries which were never intended to be published permits the historian to explore a very private world of emotional realities central both to women's lives...in nineteenthcentury America."187

Carroll Smith-Rosenberg

(1985)

187 Carroll Smith-Rosenberg, Disorderly Conduct: Visions of Gender in Victorian America (New York: Oxford University Press, 1985), 55. 
Southern elite women maintained their sense of social equality and independence within the domestic and public spheres of the American South. It is apparent, through letters and diaries, that they also reflected on their societal oppression, bonded with one another over shared experiences, supported each other both physically and emotionally, and often helped each other in daily tasks all by consistently visiting and writing to one another. Elite Southern women experienced the reality of femininity, in which they were females first, and mothers and wives second through this community.

\section{Did This Community Exist, and What Did Popular Discourse Say About This Environment?}

According to the scholar Catherine Clinton, Southern elite women were too isolated to emotionally connect with one another. Thus they did not form a feminine community that supposedly existed in the North. ${ }^{188}$ Even more, Clinton believed that traveling was "radical", and their household responsibilities kept them from fostering female friendships with others. ${ }^{189}$ Yet, despite these assumptions, a majority of the women who are referenced in this thesis journeyed consistently to visit or stay with other females they befriended over the course of their lives, and most of them wrote to their

\footnotetext{
188 Clinton, xiii.

189 Ibid., 175; Anna and Sarah Butler correspondences in Mss. 581, Louisiana and Lower Mississippi Valley Collections, LSU Libraries, Baton Rouge, Louisiana; Elizabeth Tucker Bryan Diary (1853) in Mss. 5: B8404: 1, Elizabeth Tucker Coalter Bryan Collection (1805-1856), Virginia Historical Society, Richmond, Virginia; Caroline Kean (Hill) Davis Diary (1860) in Mss. 5: 1D2913, Virginia Historical Society, Richmond, Virginia; Sarah Dandridge (Cooke) Duval Papers (1847-1864) in Mss2: D9563b, Virginia Historical Society, Richmond, Virginia; Judith Lomax Diary (1820-1827) in Mss5: 1L8378, Virginia Historical Society, Richmond, Virginia; Susan Elizabeth Webb Diary (1858) in Mss5: 1W3843, Virginia Historical Society, Richmond, Virginia.
} 
female friends and relatives on a weekly basis. Some of Clinton's evidence even reveals these women were well connected with one another, though her work does not make that link between consistent communication and a very close feminine bond. ${ }^{190}$ Indeed, they were very interactive with one another, and relied heavily on this sisterhood for guidance, help, strength, identity, and many other emotional and physical necessities.

Mainstream southern culture did not promote or condemn this feminine unity, but instead outlined a social framework that forced women to conform to a sphere that did not necessarily fuel female companionships. This said, these expectations and gender ideologies emphasized that a woman's efforts should be directed toward being a mother and wife, and nothing more. J. O. Goon, a writer for The Southern Lady companion series, made it very clear that a woman's attention should be directed nowhere but the domestic circle stating, "But it is when we contemplate home in connection with woman, her varied duties soothing hand, tender affection, kind offices, and vigilant care, that it becomes doubly interesting. This is her rightful and peculiar sphere; and how much depends on her discharging faithfully the duties above all."191 Newspapers such as these would emphasize the social position and tasks that married women were assigned in the nineteenth-century. Moreover, artistic portraits, included in this thesis, show women in their "natural" environment as obedient

190 Refer to chapter 2.

191 The Southern Lady's Companion, v. 1 (Apr. 1847-Mar. 1848) in <http://hdl.handle.net>, 228. 
mothers and wives. ${ }^{192}$ And, women's seminary schools taught remedial skills like reading, writing, cooking, basic math, and sewing in order to convey these domestic skills, chores, and hobbies to Southern elite women. ${ }^{193}$

Though social expectations directed women's efforts to the home, it is also worth noting that Southern men, especially in the elite ranks, had consistently barred women and African-American slaves from participating in politics, the law, and business. The institution of slavery is one of the best examples of this social oppression. ${ }^{194}$ Male slave owners structured society in a way that prohibited slaves from rebelling against the Southern social system. In the same vein, these men utilized isolation and domesticity to limit the influence of Southern females. Nonetheless, Southern elite women defied the male prerogative and formed strong bonds with each other to foster a feminine identity, find strength, and establish a support system.

\section{Sisterhood}

Though the structure of Southern society "tried" to keep Southern women within the world of domesticity, mistresses relied on one another to find agency and independence in a world outside of their prescribed sphere. There are hundreds of letters among these women concerning a variety of topics such as traveling, helping other females, life events, illness, daily tasks, and

\footnotetext{
192 Refer to various images in the appendix.

${ }^{193}$ Refer to figure 10 in appendix.

194 Edmund S. Morgan, American Slavery, American Freedom (New York: W.W. Norton \& Company Inc., 1975), 295-363; Edward E. Baptist, The Half Has Never Been Told: Slavery and the Making of American Capitalism (New York: Basic Books, 2014), 1-145.
} 
sometimes their aversions for certain female responsibilities that validate they regularly communicated, visited, and traveled to interact with one another. This sphere was truly important to these women, and they created this bond by any and all means.

Dolly Lunt Burge, a plantation mistress from Mansfield Georgia, lived on the Burge Estate with her husband Thomas in the 1850s. ${ }^{195}$ In 1858 her second husband passed away, and Burge continued to independently run her land through the years. During this time, she recorded her daily life in a diary that spanned two wars and countless other events in Southern history, documenting her thoughts on intellectual and social topics that circulated amongst the Southern elite class. Yet, the most important aspect about her recollections were the sisterly bonds that she and her friends created. Burge traveled and visited countless women who lived near and far to her. Burge wrote, "I am busy with my friends." In one instance, she spoke about her close friend Martha, who she visited often and also helped take care of her newborn child. She stated, "Martha has another daughter."196

In other cases, Burge aided her friends in numerous ways, including helping complete some of their daily responsibilities and supporting them through tough times. She wrote, “Went over to Mrs. Perry to see Joseph's bride accompanied by Mother \& Caroline. We have done no gardening yet.

195 Christine Carter, Ed., The Diary of Dolly Lunt Burge, 1848-1879 (Athens: University of Georgia Press, 2006); Refer to figure 19 in appendix. 196 Ibid., 72. 
Mrs. P’s cabbage plants are up." Often, she traveled to friends who were ill too. In a few instances Burge explained, "Much milder to-day called upon Mrs. Floyd early this morning her daughter is quite unwell" and "went to Sandtown and called upon Mrs. H Harwell who is sick at Mrs. Bobers with fever."197 And though these women left no records of how they felt about Burge's efforts, it is plausible that they greatly appreciated the help she offered them. Her records do show, however, that Burge's friends expressed their gratitude by helping her. At one point, she mentioned she had been very ill for over two weeks, yet grew stronger with the aid of her comrades. Mrs. Shaw, specifically, left her responsibilities at home and nursed Burge back to health. She stated, "Old Mrs. Shaw came up to day to spend the week with me. I am getting quite strong again." ${ }^{198}$ Shaw showed Burge compassion and love through her actions at a very vulnerable and precarious moment in her life.

I would argue, however, that the best piece of evidence that Burge's diary presents about the strength and love that Southern elite women showed one another was in her relationship with cousin Mary. Initially, Burge left her cousin when she first married in 1848, and moved to her new home. Nevertheless, they both continued their relationship by constantly writing and visiting each other despite the distance between them. Every few days, Burge expressed in her diary that she "wrote Cousin Mary". Similarly,

197 Carter, 5 and 64; Stephen R. Handall, Women and Addiction in the United States: 1850 to 1920 (Cambridge: First Harvard University Press, 1999), 1-21; The Southern Lady. 198 Carter, 68. 
not only did they write to each other daily, but they also stayed with one another every few months, which took great effort to plan. Burge explained, "Miss Mary is with me to night. Came in late after service-She leaves in the morning for the country." Burge and Mary often showed their affection for one another through giving each other items throughout their friendship. Burge stated, "Received letter or package from Cousin Mary today been out \& purchased her a beautiful barrage silk \&c" and hoped "cousin will be pleased with the dress." While on another occasion she "went down town...bought Cousin Mary a pair of boots edging and prepared her box to send her this evening."199 Undeniably, their mutual love and admiration for one another was evident through this beautiful and long-lasting friendship.

The head of her plantation on Georgia's coastline, Anna Matilda Page King (1798-1859) resided on St. Simon Island with her family for much of her life. ${ }^{200}$ In fact, Anna owned the Georgia plantation that her father gave her before she was married. By 1842, after her husband's countless business failures, King's family sought refuge on her personal estate. Moreover, with her spouse frequently absent throughout the year, she was left with the responsibility of taking care of her family and slaves. Comprised of over 150 letters, King's documents highlight her important role in the household, the ongoing struggles she faced providing for her family, and her persistence to

199 Ibid., 21-25.

200 Melanie Pavich-Lindsay, Ed., Anna: The Letters of a St. Simons Island Plantation Mistress, 1817-1859 (Athens: The University of Georgia Press, 2002); Refer to figure 20 in appendix; Catherine Devereux Edmondson, The Journal of Catherine Devereux Edmondston, 1860-1866. (1954) in Raleigh: Division of Archives and History, Dept. of Cultural Resources. 
keep them in the best health. These letters also reveal that she often dealt with her husband's inability to provide for the family, which placed her in a commanding position within her community and among her family members. Untypically, King's father educated her in all aspects of agrarian management which included account keeping, cultivating seeds, running a sufficient production line, and even supervising the construction of buildings. This foundation proved useful in her married years on St. Simon's Island, and with the help of over fifty slaves, she ran that plantation with little influence or aid from her husband.

Aside from King's influence and dominance as mistress of the household, her relationships with the countless women who entered and greatly influenced her life were just as important. ${ }^{201}$ Editor Melanie PavichLindsay stated that King "used letters to family and friends as both a means of communication and a sorely needed opportunity to pour out some of her innermost thoughts." ${ }^{202}$ To compensate for how isolated coastal living was, King often entertained and hosted friends throughout the year, and enjoyed being around her female friends and family. King wrote to her son that she hosted her friend Tootie and family who "dined with us on Saturday" and

\footnotetext{
${ }^{201}$ King's experience is one of the most prevalent pieces of evidence that show just how powerful mistresses were within the domestic sphere, and demonstrate how some of these females were more than just "housewives". 202 Pavich-Lindsay, viii.
} 
while they were there she helped "Tootie sew. Malty-Cousin AmandaFlorence and myself did most."203

Among King's most precious relationships, however, was her intimate friendship with Amanda Fitzallen Scott was the strongest. According to editor Pavich-Lindsay this woman "was, in essence, the sister Anna never had, and the two women maintained a lifelong bond of love, friendship, and support" throughout their lives. ${ }^{204}$ Amanda was King's greatest support system and sisterly confidante. Often, she declared her love for Amanda stating, "On return of the boat I had the happiness to receive one I love next to my husband \& children-our dear Cousin Amanda." ${ }^{205}$ Relying on her cousin to help her in many areas, often she wished that "Cousin Amanda could only have come last week-what a relief it would have been to me."206 On another occasion, King planned Amanda's return before she even left her home stating, "Amanda leaves us in two days and has promised to return here on the 2nd week in August." 207 Yet King was most content when "My dear Amanda still remains with me which is a great comfort to me...I shall miss my dear Cousin very much."208

King and Amanda wrote to one another often to discuss various things. She told her husband, "I had a letter last week from Amanda she

\footnotetext{
203 Pavich-Lindsay, 213.

204 Ibid., xxvvii.

205 Ibid., 242.

206 Ibid., 41.

207 Ibid., 91.

208 Ibid., 91 \& 93.
} 
mentioned that she intended to return home the first of March and could not come here which I regret very much."209 Of course, King's most cherished moments with Amanda occurred when they needed each other. For instance, Amanda took care of King when she was very ill throughout the week of and on Christmas Eve. For most families, this season was very busy since there were festivals, family visits, dinner parties, and religious services. Plus, King was a lone provider of her household, having to feed, clothe, and financially support everyone. Therefore, it was a huge imposition for her to be ill so long, let alone during this time. Understanding this predicament, Amanda left her responsibilities at home to attend to her cousin and take care of King's daily tasks until she recovered. At one-point Anna noted in a letter to her brother that "with no other aid...my dear Amanda had to dress the child."210 Amanda truly was her best friend, and there were countless other times when she relied on her cousin for strength, guidance, and companionship. King reiterated to her son that "She has ever proved herself to be our grateful true friend in sickness-in time of prosperity-in time of adversity in joy \& in sorrow-always." 211 Anna King, like other Southern elite women, realized the importance of her feminine circle that was filled with support, trust, and admiration for one another.

\footnotetext{
209 Pavich-Lindsay, 4.

210 Ibid., 8.

211 Ibid., 275.
} 
Written between July 1860 and April 1861, the Diary of Keziah Goodwyn Hopkins Brevard, revealed a very no-nonsense and managerial persona toward the prosperity of her home and business. ${ }^{212}$ At the age of fifty-seven, Brevard lived on her South Carolina plantation which she inherited from her father in 1844. By 1886, she more than doubled her land holdings through various business ventures, but also fully controlled the inner workings of her home by cooking, cleaning, preserving food, and making clothing. ${ }^{213}$ Brevard's diary, among other things, documented her interaction as a slave mistress and domestic overseer in which she took great pride in her ability to run a "tight ship." ${ }^{214}$ Beyond this, her journal also highlights how politically engaged she was on the eve of the Civil War, referring to events such as the election of Lincoln, South Carolina's secession, and the attack on Fort Sumter. ${ }^{215}$

Conversely, Brevard's communication with her female friends remains the most relevant aspect of her journal. She visited other women constantly over the years, hosted dinners for them, and invited these females in to stay at her home as well. One occasion consisted of "Randolph-his wife Kate-Laura-Ellen-Caroline and little Jamie spent the afternoon with me-All of us walked out-some gathering grapes-some for pleasure."216 On September

${ }^{212}$ John Hammond, Ed., A Plantation Mistress on the Eve of the Civil War: The Diary of Keziah Goodwyn Hopkins Brevard, 1860-1861 (Columbia: University of South Carolina Press, 1993).

213 Ibid., vii.

${ }^{214}$ Refer to chapter one.

${ }^{215}$ Refer to chapter two.

${ }^{216}$ Hammond, 30. 
1860 "Anne called to see me and asked me to go over tomorrow evening and see them..." ${ }^{217}$ And, yesterday "I went on to Mrs. F. M. Hopkins and sat with her till near sun down-I found Mrs. Ray and three little girls with her-Fanny as usual much engaged with her front law and gardens."218 Not only did Brevard long for her female network, but she willingly gave her friends money to help with their expenses when it was necessary. She "gave JaneMrs. A-ten dollars-and M. A. Brooks twenty-dollars" to help with their expenses. ${ }^{219}$ This act speaks volumes at a time when funds, commodities, and agriculture hung in the balance for many Southerners who suffered during the Civil War. Despite this, she willingly gave what she had to ensure other women in her life survived. Brevard's friends also reciprocated her personal gestures by calling on her as well. Brevard "heard Mrs. Jones-Kate and Laura called yesterday evening. Truly sorry they came while I was absent, for I love to see them all."220

Yet, Brevard's most important female confidant was her cousin and friend Emma Hopkins, whom she spoke about, stayed with, and corresponded with almost every day. John Hammond, the editor of her diary, explained that "Keziah's closest friend was her "Cousin Emma" (1808-1868), wife of General William Hopkins (1805-1863)."221 She depended on Emma's companionship for guidance, strength, and support during difficult times in

217 Hammond, 33.

218 Ibid., 77.

${ }^{219}$ Ibid., 51.

220 Ibid., 32.

${ }^{221}$ Ibid., 7. 
her life. Brevard stated, "I am feeling very badly. I went to Emma's."222 On another day she "left Cabin branch at 6 O'clock A.M. came back \& went and dined with Emma." 223 Brevard's weekly visits or long stays with her cousin gave her a break from responsibilities, and she often found support with Emma in times of emotional and physical crises as well. She stated, "in the afternoon I left Emma and went to my cabin branch place" and "went to Emma's to dinner and remained all night." 224 And when their communication stalled Brevard often felt dismay and hurt. She stated, "Sunday 17th: I thought it strange Emma had not been to see me."225 Identical to other mistresses' diaries and letters, Brevard's female friendships were an integral and important part of her life.

Residing on a Georgia plantation, Maria Bryan Harford Connell lived a privileged and busy life through her travels, marriage, family, and social events. ${ }^{226}$ Connell, frequently entertained numerous women, communicated with her friends, and went to great lengths to visit them throughout her life. She wrote in a letter, "I was quite pleased with my visit there, and made some rather pleasant acquaintances."227 While on vacation, she often asked numerous women to write her, and she wrote to everyone back home in return. Connell stated, "I meant to have written to you at length from New

\footnotetext{
222 Hammond, 23.

223 Ibid., 21 \& 101.

224 Ibid., 24.

225 Ibid., 100.

${ }^{226}$ Carol Bleser. Ed., Tokens of Affection: The Letters of a Planter's Daughter in the Old South (Athens: The University of Georgia Press, 1996).

227 Ibid., 133.
} 
York, and was prevented from the hope each day that I should hear from you." ${ }^{228}$ Even when traveling, "I repeatedly requested you to write to New York to send every day, to the office, until the Post Master, Mr. Harford said, appeared really tired out with looking." 229 She thrived on communicating with her female friends no matter how far she was from home. Connell also showed affection and understanding toward her friends by sending them important necessities as well. She stated, "I am sorry the preserves turned out so badly, but I think if you had boiled them over they might have done for ordinary times. I am glad you like the pickles."230 And on other occasions, Connell's companions reciprocated by sending her items as well. She wrote, "I am much obliged to you, my dear Julia, for your offer about my frock and, indeed, for all your kindness. I feel it far more than I can ever express, but I shall not need a new one this summer."231

Though Connell maintained a strong network of female friends, her sister Julia Ann Bryan Cumming was her greatest confidant and best friend. Carol Bleser, who edited her diary, stated, "Her affectionate admiration for her older sister Julia was boundless."232 When Connell was not traveling or entertaining guests, she often felt the isolation of plantation life, and among other things experienced sadness, loss, and loneliness. Yet, Julia brought her much needed interaction with people outside the household, but also the

\footnotetext{
228 Bleser.

229 Ibid.

230 Ibid., 211.

231 Ibid., 203.

232 Ibid., xxvii.
} 
sisterly support she required as well. One letter explained how dejected she was over the loss of a cow, reflecting her inability to protect an important commodity for her family. In this sad moment Connell expressed to Julia, "You know that your letters are always sufficiently welcome, but none ever was more so than the one that was sent to me this afternoon from the garrison...I have really been in sorrow today from having lost our poor cow last night."233 Moreover, when she experienced days filled with complications, she would write to her sister for guidance. On one occasion, Connell received a letter from Julia on a particularly difficult day stating, "I return you a thousand thanks, my dear Julia, for your kind letter which was like a draught of refreshing water to the hot and thirsty life of the worn-out pilgrim.." ${ }^{234}$ It is clear from her diary that Connell and Julia supported each other through various life events.

Rosalie Stier Calvert's experience was a bit different from the preceding women..$^{235}$ Traveling to America from Belgium, she married a wealthy plantation owner name George Calvert, and lived on their Prince George County, Maryland estate until her death in 1821. Once Calvert married, her familial support system dissolved as her family returned home to Belgium, while she remained in the United States and assumed her role as mistress of Riversdale Plantation. George and Rosalie's 738-acre plantation

\footnotetext{
233 Bleser, 150.

234 Ibid., 133.

235 Margaret Law Callcott. Ed., Mistress of Riversdale: The Plantation Letters of Rosalie Stier Calvert, 1795-1821 (Baltimore: John Hopkins University Press, 1991); Refer to figure 22 in appendix.
} 
included a Georgian mansion that was built between 1802-1808, and housed at least sixty slaves. Despite being separated from her family and missing them often, however, she adapted quickly to her surroundings. Throughout her time in the U.S., Calvert would have nine children, five of whom survived to adulthood. The surviving letters she wrote to her family back home, her in-laws, and the few friends she had in the U.S. speak of struggles, friendships, love, and heart ache that she experienced as an elite woman of the South. Calvert confessed that "a very nice little circle of neighbors whom we see often and unceremoniously" occupied much of her time in Maryland.

Though she frequently spoke about visiting females around Riversdale, Mrs. Lowdnes and Mrs. Law received most of her letters. Law was her niece by marriage, and Lowdnes was a close family friend. Margaret Callcott, editor of Calvert's letters, stated “Mrs. Lowndes filled a particularly significant void in Rosalie Calvert's life. Here, finally, was a friend...she liked and respected...whom to confide and share experiences...Scarcely a day passed without communication...and their friendship lasted until Rosalie's death." 236 Calvert confirmed, "We are quite close to the Dick Lowndes' familyhis wife is very nice and a respectable woman... and who improve upon acquaintance."237 As Calvert passed her days on Riversdale Plantation she found that Lowdnes was "an excellent woman and few days pass without communication between us. Sometimes we write each other notes twice a

${ }^{236}$ Callcott, 136.

237 Ibid., 112-128. 
day."238 However, Lowdnes' greatest testament to her friendship with Calvert occurred at Rosalie's bedside. She died at the age of forty-three, and Lowdnes remained with her until the end. Editor Callcott stated that George Calvert wrote "a letter to Rosalie's sister, Isabelle van Havre (March 18, 1821)" and in it "Calvert reported that his wife had been attended in her final illness by her good friend and neighbor, Anne Lowndes." The last act Lowndes performed for her friend was one of true friendship. Calvert found an important companion in Mrs. Law as well, and both of them relied on one another in various ways. On one occasion, she hosted her friend during a very unsettling and personal event in Law's life: she was divorcing her husband and resided at Riversdale until she arranged for permanent accommodations. Calvert wrote her husband that Mrs. Law "is separated from her husband. She is with me at the present and is considering buying the Stoddert House."239 Rosalie Calvert's emotional support system contained, more than anyone else, her female network of friends in the United States.

Finally, the last three examples consist of the diary of Ella Gertrude Clanton Thomas, along with the letters of Caroline Merrick and the Butler sisters, which reinforce the idea that not only did this community of women exist, but also that these females relied on this community for various reasons. Ella Gertrude Clanton Thomas resided in Augusta Georgia where she

238 Callcott, 176.

${ }^{239}$ Ibid., "To H.J. Stier", 97. 
spent her childhood and adult life among the planter class. ${ }^{240}$ Thomas, rare for a woman of her day, was one of the few who was highly educated. She attended Georgia's Wesleyan Female College in her young adult life, and after graduating she married and resided on her large plantation estate until her death in 1907. Thomas' diary, spanning the years between 1848 to 1889 , documented civilian life-describing poverty, day-to-day tasks, and political and economic upheaval—during a tumultuous period of war and turmoil in the South. One of the most important aspects of Thomas' diary was her bond with various females that relieved the stress and social constriction of her daily life. She wrote in one letter, "I have received a good many letters from home and from the girls since I have been here. Isabel Morrison Jane McKeen Bea Gardner and one or two others....Some of the girls I am very much attached to."241 In addition, her journal often recalled countless visits with close friends. Thomas explained, "I expect to go out visiting tomorrow as I owe a great many visits. I want to go and see Lizzy Wilson, Mary Ann D’Antignac, Mary Dugas, and several others."242 Most important, however, Thomas naming her child after her close friend Isabel Morrison was one of the greatest testaments to the bond between females. She stated, "I have concluded to call her Mary for Ma and Mamie and think I will add Isabel for Isabel Morrison."243

240 Virginia Ingraham Burr. Ed., The Secret Eye: The Journal of Ella Gertrude Clanton Thomas,1848-1889 (Chapel Hill: The University of North Carolina Press, 1990).

${ }^{241}$ Ibid., 83.

242 Ibid., 80.

${ }^{243}$ Ibid., 164. 
Despite Thomas' worldly connections and her tight-knight female network, she was closest with her friends Julia and Mat Wood. In fact, Thomas' friendship with Julia meant everything to her, and both women were extremely close to one another. She stated of Julia, "Yesterday after dinner we went down to see her. Her child is quite large and as far as I can judge looks more like Mr. Scales."244 Moreover, Wood was one of Thomas' "dearest friends...around whom the closest tendrils of affection continue to twine." Even after Wood married she "still continues to write to me and her letters have a more cheerful tone."245 Though Thomas remained close to Wood for years, at one point in their relationship she initially grieved the loss of her friend when Wood was engaged. As soon as "I read the invitation to Mat's wedding I wept oh so bitterly. That dear Mat, how sad is the reflection that she is married."246 After Wood's matrimony, Thomas suffered extreme anxiety over the thought of not seeing her again stating, "Well it is over. Mat is indeed married!" and though "she still continues to write me...she still feels the aching void which nothing she says can ever fill."247

Juliana Margaret Conner, a Charleston, South Carolina resident, lived with her husband both in the city and in the country throughout her life.248 Though her travel diary only spanned the year of 1827 , Conner and her

\footnotetext{
244 Burr, 125.

245 Ibid., 159.

246 Ibid., 106.

247 Ibid., 122 \& 108.

${ }^{248}$ Juliana Margaret Conner Diary (1827) in Juliana Margaret Courtney Conner Diary \#174-z, Southern Historical Collection, The Wilson Library, University of North Carolina at Chapel Hill; Elizabeth Washington Grist Knox Papers, Series 1.4, Fol. 12 (1846-1850).
} 
husband journeyed across numerous states to visit family and friends. During this time, Conner's journal revealed her close bond with various women that she made an effort to see along the way, but also her willingness to make new feminine networks as well. She explained in one diary entry that she "Dined at Mrs. McBree-an excellent house" and "paid a visit from Mrs. Mclaughlin a pretty entertaining, intelligent lady, easy and affordable manners." ${ }^{249}$ Conner's journal likewise shows that Southern elite women were much more mobile than what historians, such as Clinton, have previously documented. Like Conner, other mistresses often traveled to places outside their homes for recreation and necessity. Last, Caroline Merrick, the wife of a judge and resident of New Orleans, was a powerful figure in Louisiana society. She often spoke about women's rights, and served on various charity committees and institutional boards as well. Her close friends were the greatest support system behind her motivation to live equal to men. Merrick wrote to a friend that "I...am determined to be more content...in the future."250 Repeatedly, they were her guiding force in everything she accomplished, and many of them listened to her thoughts about gender equality and social progress too.

Finally, the bond among Anna and Sarah Butler and their friends is one of the most compelling examples of a feminine social network. Both

\footnotetext{
${ }^{249}$ Conner, $26 \& 47$.

${ }^{250}$ Caroline Merrick to "Dear Friend" (18 September 1855 \& 27 December 1858) in Honoré P. Morancy Family Papers, Mss. 2430, Louisiana and Lower Mississippi Valley Collections, LSU Libraries, Baton Rouge, La.
} 
sisters and their friends communicated regularly with one another disclosing some of their most personal details within this intimate and private sisterhood. Together, they experienced both happy and sad events throughout their lives, but also sought each other out for guidance and support. One very sad occasion that occurred among this group of females was when they lost a close friend named Eliza Skiles, who passed away at a young age. Not only were they saddened by the tragedy, but both sisters also cut out her obituary in their local newspaper where it now remains in the Butler papers to this day. ${ }^{251}$ Often, the girls communicated among one another regarding travel plans, attending parties, gossip, visiting each other, and much more as well. For instance, Anne Butler's friend Jane spoke about traveling to her aunt's house upon receiving "an invitation from Cousin Nancy for me to go north with her, and a letter from my aunt, the best aunt that ever was offering many inducements...to accept of Cousin Nancy's kindness." ${ }^{252}$ If there was evidence that expressed the strength, impact, and importance of female networks it is within this collection of letters and other items that belonged to Anne, Sarah, and their female friends.

Norman Fairclough stated in his research on power, identity, and discourse that "The idea of 'power behind discourse' is that the whole social order of discourse is put together and held together as a hidden effect of

${ }^{251}$ Mary to Anne Butler, "Dear Cousin Anne" (1848) in Anne and Sarah Butler Papers; Refer to figure 12 in appendix.

252 Jane to Anne Butler, "Miss Anne" (16 June 1844) in Anne and Sarah Butler Correspondences. 
power." In other words, control "is exercised and enacted in discourse, and on the other hand that there are relations of power behind discourse" itself.. ${ }^{253}$ All of the women mentioned in this chapter, and others like them, benefitted from having close female friends in their lives to one degree or another. By applying Fairclough's premise, we can see that Southern elite women were motivated to bond over their shared circumstances as a mechanism to foster individuality, autonomy, and self-worth among each other in their own world. More important, this chapter, if anything, proves that a feminine community existed. In this sisterhood, Southern elite women identified as females, first, and as wives and mothers, second. As Nancy Cott explained, "A woman discovered among her own sex a world of true peers, in valuing whom she confirmed her own value" and it was "not until they saw themselves thus classed by sex would women join to protest their sexual fate."254 In a world where their every move was critiqued and men centered themselves in the heart of Southern society, they emerged as strong and independent females.

${ }^{253}$ Norman Fairclough, Language and Power (Harlow: Pearson Education Limited, 1989), 4661. ${ }^{254}$ Cott, 190-206. 
CHAPTER FOUR

CONCLUSIONS 
I highlighted, in this study, how the three most prominent spheres within womanhood positively influenced an elite woman's agency, power, and independence within the American South before the Civil War. In the end, the domestic, public, and feminine spheres were spatial areas that allowed elite Southern women to push gender boundaries in ways that elevated their social status, and fueled their desire to be heard and seen within this culture.

To date only three scholars, Elizabeth Varon, Suzanne Lebsock, and Anne Firor Scott have addressed the topic of Southern elite women and feminine agency, and all three argued that these females were in much more powerful positions than previously believed. I followed their lead and attempted to expand upon their conclusions by using a broader sample of women and a different methodological approach to analyze female agency in Southern history. Though this study relied on archives found in six states and focused on women from different backgrounds, it concentrated on wives and mothers who lived in fixed points of time, rather than described a gradual progression toward feminism. Nonetheless, this research is the start toward a comprehensive study of Southern women and feminism.

In addition, my work addresses an idea that Fox-Genovese referenced in her book, and a concept that is highly debatable among historians of feminist history. Do we incorporate race and class in our research of feminism, gender, and women in American history? Or will this overshadow the female perspective and place women within a male-centric 
historiography? My research concludes multiple ideas on this issue. One, it is extremely important to explore notions of gender, race, and class simultaneously among these women because they, themselves, categorized each other among various social labels that should be incorporated in the history of their perspectives. Second, gender continues to be a fundamental research prism that is equal to the studies of race and class in American society, especially among these people specifically. This research proved that all three categories were necessary investigative tools to study this topic and these people since Southern elite women's racial, class, and gender statuses were all equal and contributing factors in segregating them within the sphere of womanhood. Thus, we must continue to analyze people within multiple social categories in order to understand our history.

Though I tried to investigate this topic as thoroughly as possible there are things that need to be addressed in subsequent studies. One, combining "agency" and "feminism" into one concept will continue to be unresolved in this thesis. I have, however, sought to develop a valid basis of research concerning these women's journey toward collective feminization over time on the premise that "agency" is the foundation for feminist thought. Based on this idea, Southern elite women embodied qualities of self-worth, feminine identity, independence, and social resistance through their behaviors within womanhood, which are key elements of what we consider to be a feminist. Two, many mistresses did perform social duties that "seemed" to support this male-centric society. Nonetheless, how much of this performance was 
their willingness perpetuate this system as opposed to their protection of a structure that allowed them to elevate their position in Southern culture? Why was it necessary to have perfectly manicured homes to the point that they were extremely violent against their house slaves? Why was it necessary for them to be in complete control of their domestic space? Why did they feel it was vital to raise their children, wear matching clothing, control fertility, and have almost complete control over their children's lessons? Why did they perform duties that sometimes defied gender expectations? What do the actions of some radical Southern women—who fought for female rights—say about other females' potential as Southern feminists? Why was it necessary to build strong relationships with other women in the South? And, why was it important, for many of them, to fight for social progress? My work explains that these actions were the beginning of Southern women fighting against their oppression more than a defense of the patriarchal south. By looking at women's behaviors within this system we can pinpoint instances where we see manipulation or out-right revolt against social norms as a direct link to feminism. In other words, it appears as if they were complying with cultural expectations, but looking deeper we can see that they were using this system to solidify their place and dominance in the American South.

I have little doubt that these females were feminists in their own way, and it is important that we continue to investigate this topic to paint a more favorable picture of Southern mistresses' powerful social presence in the patriarchal South. Though I could only research a fraction of the evidence 
that we possess of these females and their world, with more time, scholars can piece together the journey Southern women took to find gender equality among their own kind.

Moving forward, there are numerous hurdles that scholars must overcome in order to write a new social history of Southern women, and a new understanding of nineteenth-century feminism as well. First, academics must apply different methodologies to their work. For the most part, the studies of Southern women and feminine agency heavily rely on structural interpretations of personal documents, yet there are sources that could benefit from psychological, statistical, and post-structural analyses as well. For instance, Lebsock's utilization of data is important, yet she is the only scholar who relied on numerical figures to study these females, and even then her evidence was sparse and narrow. It is imperative that we employ census records, probate records, and other data as much as we can in order to calculate human behavior in quantities such as how many women fully operated their homes without their spouses, and found independence and agency as sole providers. In addition, researching men's travel patterns, and how frequently they resided in their homes could illustrate how often mistresses were running their family estates by themselves as well. Thus, the study of Southern women's history will become more definitive if we analyze these sources in a variety of ways. 
Second, a more detailed analysis of women's letters and diaries could reveal how far their feminine network extended, the variety of topics women of different ages discussed, and even identify females who shared feminist sentiments. This area of Southern women's lives is a viable space to understand mistresses' fight for social autonomy through "sisterhood", as Nancy Cott explored among New England females. Although Chapter Three proved that this group existed and that these women relied heavily on one another for support, we now need to expand on this approach to dispute Clinton's assumption that these women were not capable of bonding over their shared oppression. Once done, we can link this feminine community to Southern women's fight for feminism after the Civil War. Third, there are countless other documents that need to be examined, which pertain to elite mistresses' lives prior to the Civil War. Although I read over one thousand sources concerning Southern women's social experiences, there are many stones still unturned among family and university papers. Fourth, scholars need to start the process of moving toward a new social history of these women by synthesizing existing histories of these females, from various points in the nineteenth-century, into a larger framework to portray an overall picture of their long fight for equality in the South.

Fifth, scholars need to redefine "feminism" and elaborate on the different stages and degrees of female social resistance that occurred in U.S. history since certain women supposedly do not fit the criteria of what it means to be a feminist. If women did not radically protest their social status 
they were not feminists; if they did not participate or agree with the feminist movements of the nineteenth-century they were not feminists; if they did not speak directly about or fight for others' social injustices they were not feminists; and, if they did not abandon their responsibilities as housewives they were not feminists. This structure is too limiting, and overshadows what it truly meant to be a woman who valued her self-worth in America. Quite the opposite, some women were more conservative feminists, fighting for civil rights through more reserved tactics such as lobbying elite political members, attending parties and making connections, or other means that were conducive to their social image yet practical for their goals. Others, were cultural feminists who were more comfortable passing messages along and educating people about women's rights rather than associating with actual groups. And there were radical feminists, such as the Grimke sisters, who became heavily involved in the feminist movement not just for women in the North but for all females in America. Moreover, Southern women's fight for agency and equality is a perfect example of how intricate and complicated human perspectives can get. They fought for social freedom in a very unique way by utilizing what they had to gain leverage and control over themselves and their surroundings. Even more, Southern elite women were already very powerful within their sphere, thus their fight for agency varied compared to New England women. ${ }^{255}$ They did not need the Feminist

255 Smith, Inside the Great House, 17; Stansell, City of Women, 1-217; Cott, Bonds 1-160; Anthony Rotunda, American Manhood 1-284. 
Movement to fight for social elevation, but instead found agency, independence, and identity as "Moral Reformers", "Mistresses", and "Southern Sisterly Females".

Sixth, scholars tend to place labels on people's perspectives and behaviors that further segregate male and female viewpoints in history, when these characteristics were not necessarily consistent in primary source records. Almost none of the documents I examined mentioned titles such as "Master" and "Mistress," yet scholars label Southern elite men and women with these terms. Though this might help differentiate people of inferior status, it only off-balances men and women of the same classes, and lowers women's status in the process. In reality, planter wives and husbands called one another by their names or used terms of endearment as they worked together toward certain life goals. Does this then prove that Southern people saw themselves more socially equal than previously thought? Maybe. Further, Southern women's social positon did not necessarily deteriorate after matrimony either. For some pairs, there was mutual love and respect for one another throughout their times together. While on the other hand, some couples respected each other yet took advantage of this business and social contract that BOTH parties upheld to exist in a culture that valued, more than anything else, common goals of prosperity, procreation, legacy, and monetary wealth. Even more, the brutality that existed between masters and slaves absolutely had an impact on their marriages, and possibly affected Southern elite women's views about themselves and their significant others. 
Yet, the fact that women, in many cases, were just as violent as their husbands validate they were not necessarily shocked by this abuse, but that they, sadly, also embraced it to solidify their powerful social position. The point, however, is that there were common goals held by both parties, and love and respect did exist among many couples in the South. Therefore, placing southern men and women on varied levels of power with these fabricated labels only widens the social gap between the two. ${ }^{256}$

Seventh, most of the investigations about Southern women point out that they lived more regulated lives than females in the North. This opinion is the greatest factor as to why women of the American South have been removed from feminist history. Yet, were they very dissimilar? Northern and Southern females followed parallel paths in their fight for purpose and importance in American society. However, they diverged when it came to participating in the first wave of the Feminist Movement. In general, most women wanted their efforts to bring more opportunities to themselves and their children during the nineteenth-century. But, when structural changes occurred during this period, most women lost a great deal of autonomy among their families. As a result, both Northern and Southern females manipulated their gender spheres to find the responsibilities that restored purpose in their lives. In the end, when women in the South believed something was taken from them that offset their equality to others, they

${ }^{256}$ Refer to chapter 1 where it explains Ann Butler's decision to fire a home tutor, and pull her other child out of school without the consent of her husband. 
searched for ways to level themselves again with different resources, no matter their circumstances.

Finally, how we represent these females in the historiography is an issue in itself as well. Scholars of women's history have often considered how to analyze women's lives and their agency in American history. Presently, academics have employed two research approaches to the study of women and feminism. Traditionally, historians of women's history have framed their research around a thesis of "decline" showing a decrease in agency and power among American women, while also highlighting their gradual resistance to this oppression as well. Yet, is this the best way to analyze Southern women's fight for autonomy?

Concerning Southern elite women, going this route places men at the center of these investigations and overshadows any idea that women transcended their social roles to find feminine agency. Moreover, the female perspective is lost in this greater structure of patriarchy, which defeats the purpose of this discipline in the first place. Nevertheless, numerous scholars utilize this method to analyze Southern females, which only proves that the patriarchal world of the South was the dominant force and that mistresses were just appendages. I completely disagree with this approach. On the other hand, a more conducive method to represent Southern females in a wellrounded perspective does exist. I suggest we use this idea of "spatial agency" to further current research. What is this concept? This method examines 
human resistance to social expectations by investigating how people-in my case Southern women-were affected by their cultural surroundings, and how they utilized these circumstances to then fight for a higher social position in their communities. Southern elite women were not necessarily a product of their society, they were a fundamental part of forming and maintaining it. As such, mistresses can be reincorporated into Feminist History by analyzing their lives through this method and representing their collective journey toward social equality, which I have briefly done in this research.

I hope that this investigation, if anything, changes the tone of how previous scholarship has approached the study of Southern women and feminism, but also brings to light how resourceful and powerful these females were in the antebellum South. Southern elite women were much more multi-dimensional and powerful than some academics credit them for. Against the great opposition of a male dominated world, women of the American South fought for the right to be heard and seen in their societies. Going forward, let us acknowledge this struggle by incorporating their experiences in the history of American Feminism once and for all. 


\section{APPENDIX}

Figure 1: Maude Cowles, "She was Never Anything but Tender with the Others" in Social Life in Old Virginia Before the War (1897) (UNC:

Documenting the American South).

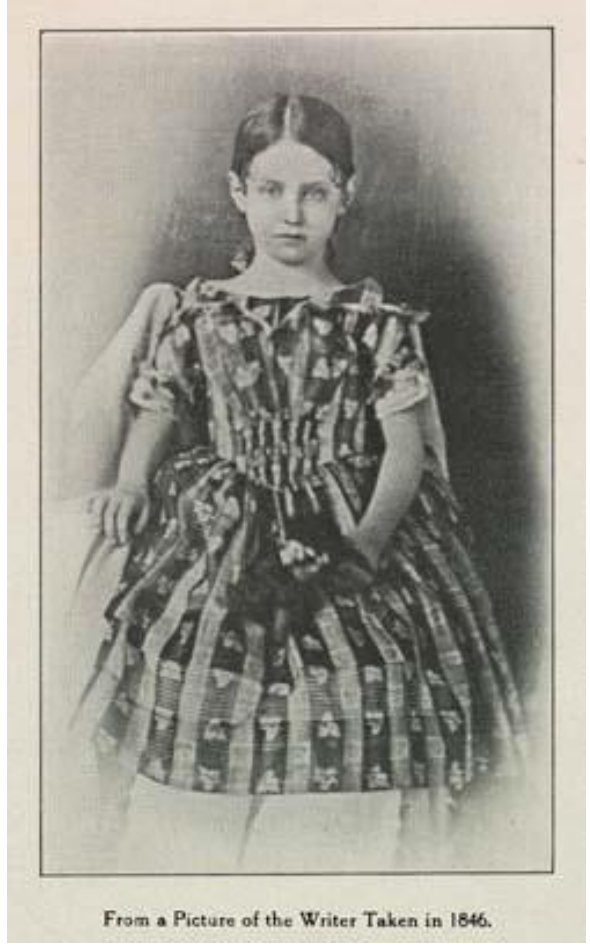



"She was never anything but tender with the others."

Figure 2: Mary Norcott Bryan, "From a Picture of the Writer Taken in 1846" in $A$ Grandmother's Recollection of Dixie (1846) (UNC: Documenting the American South). 
Figure 3: “How Dey Does Grow!” in A Grandmother's Recollection of Dixie (1846) (UNC: Documenting the American South).

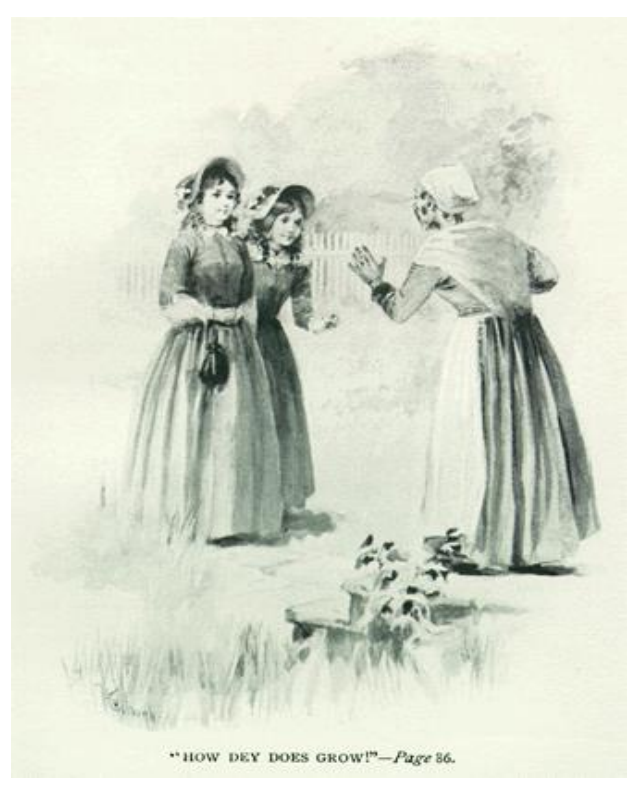

Figure 4: "Franklinton Schools, N.C.: Report" (1863) (Joyner Family Papers \#4428, Southern Historical Collection, The Wilson Library, University of North Carolina at Chapel Hill.)

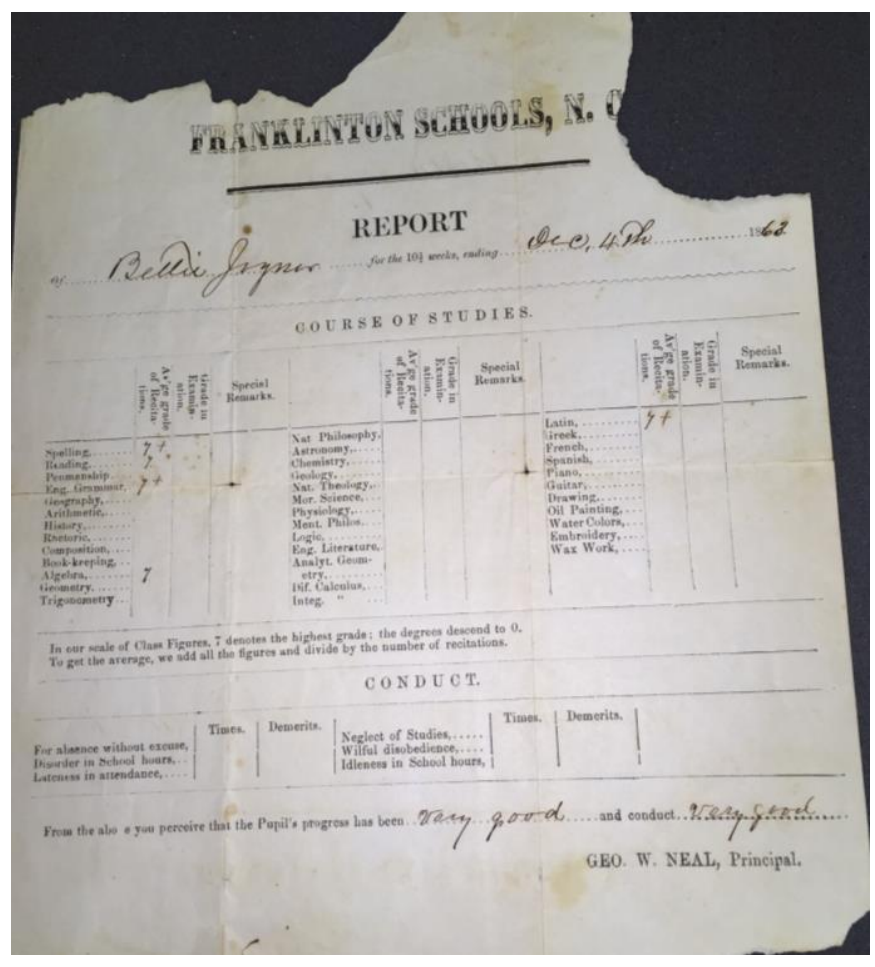


Figure 5: "Annual Concert by the Young Ladies of Raleigh Female Seminary" (1874) (Joyner Family Papers \#4428, Southern Historical Collection, The Wilson Library, University of North Carolina at Chapel Hill.)

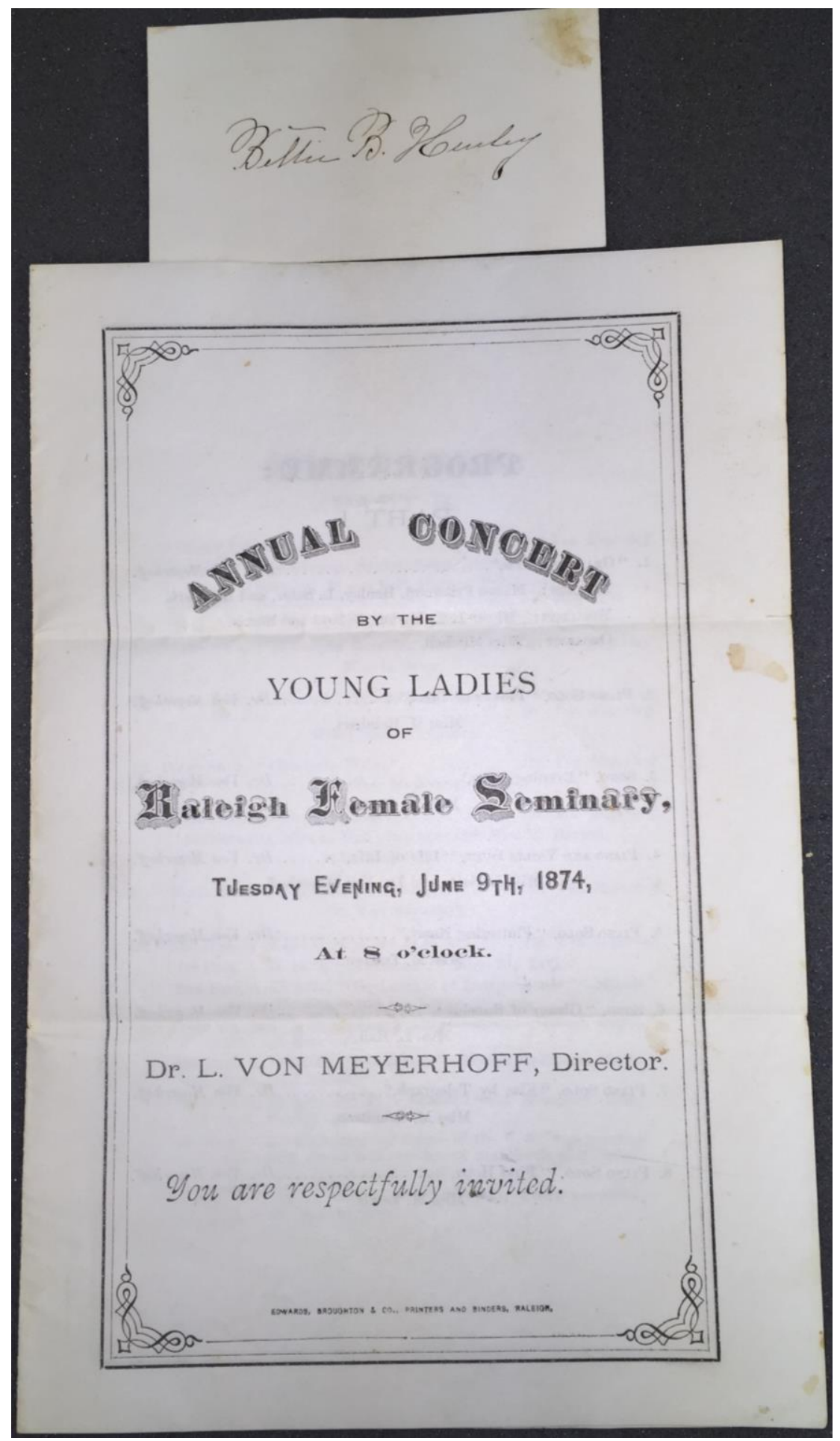


Figure 6: "A Discretion Spectrum: Terms of Wives' Inheritance" (1831-1860) in Suzanne Lebsock's, Freewomen of Petersburg: Status and Culture in a Southern Town, 1784-1860.

Table 2.2

A Discretion Spectrum: Terms of Wives' Inheritance

\begin{tabular}{|c|c|c|c|c|c|c|}
\hline Status as executor & & Nature of inheritance & & $\begin{array}{l}\text { mber of widows } \\
1784-1830\end{array}$ & & $\begin{array}{l}\text { mber of widows } \\
1831-60\end{array}$ \\
\hline $\begin{array}{l}\text { Sole executor } \\
\text { Sole executor } \\
\text { Coexecutor } \\
\text { Coexecutor }\end{array}$ & $\begin{array}{l}\text { and } \\
\text { and } \\
\text { and } \\
\text { and }\end{array}$ & $\begin{array}{l}\text { Entire inheritance in fee } \\
\text { Part inheritance in fee } \\
\text { Entire inheritance in fee } \\
\text { Part inheritance in fee }\end{array}$ & $\left.\begin{array}{r}16 \\
2 \\
10 \\
7\end{array}\right\}$ & $\begin{array}{l}\text { Major } \\
\text { discretion } \\
30.7 \%\end{array}$ & $\left.\begin{array}{r}23 \\
\mathrm{I} \\
4 \\
2\end{array}\right\}$ & $\begin{array}{l}\text { Major } \\
\text { discretion } \\
28.8 \%\end{array}$ \\
\hline $\begin{array}{l}\text { Sole executor } \\
\text { Coexecutor } \\
\text { Excluded } \\
\text { Excluded } \\
\text { None named } \\
\text { None named }\end{array}$ & $\begin{array}{l}\text { but } \\
\text { but } \\
\text { but } \\
\text { but } \\
\text { but } \\
\text { but }\end{array}$ & $\begin{array}{l}\text { Inheritance for life only } \\
\text { Inheritance for life only } \\
\text { Part inheritance in fee } \\
\text { Entire inheritance in fee } \\
\text { Entire inheritance in fee } \\
\text { Part inheritance in fee }\end{array}$ & $\left.\begin{array}{r}6 \\
\text { I4 } \\
\text { II } \\
12 \\
9 \\
2\end{array}\right\}$ & $\begin{array}{l}\text { Partial } \\
\text { discretion } \\
47.4 \%\end{array}$ & $\left.\begin{array}{r}\mathrm{I} 3 \\
\mathrm{I} \\
19 \\
14 \\
2 \\
4\end{array}\right\}$ & $\begin{array}{l}\text { Partial } \\
\text { discretion } \\
51.0 \%\end{array}$ \\
\hline $\begin{array}{l}\text { Excluded } \\
\text { None named }\end{array}$ & $\begin{array}{l}\text { and } \\
\text { and }\end{array}$ & $\begin{array}{l}\text { Inheritance for life only } \\
\text { Inheritance for life only }\end{array}$ & $\left.\begin{array}{r}22 \\
3\end{array}\right\}$ & $\begin{array}{l}\text { No discretion } \\
21.9 \%\end{array}$ & $\left.\begin{array}{r}17 \\
4\end{array}\right\}$ & $\begin{array}{l}\text { No discretion } \\
20.1 \%\end{array}$ \\
\hline
\end{tabular}

Figure 7: "Women's Participation in Real Estate and Credit Transactions" (1784-1860) in Suzanne Lebsock, Freewomen of Petersburg: Status and Culture in a Southern Town.

130 / The Free Women of Petersburg

Table S.I

Women's Participation in Real Estate and Credit

TRANSACTIONS, I 784-I860

\begin{abstract}
Real estate sales by

women
\end{abstract}

I 784-I 800

I 8OI-IO

I 8 I I -20

I 82 I -30

I 83 I -40

I $84 \mathrm{I}-50$

I $85 \mathrm{I}-60$

\section{Real estate purchases by women}

I 8
I 2
28
34
70
I 16
I 89

28

34

16

I 89
Female debtors

7
6
20
18
30
45
83

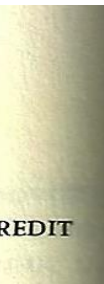

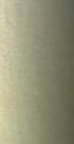

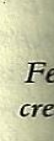


Figure 8: "Account Book of Sarah Graves" (UNC: Southern Historical Collection)

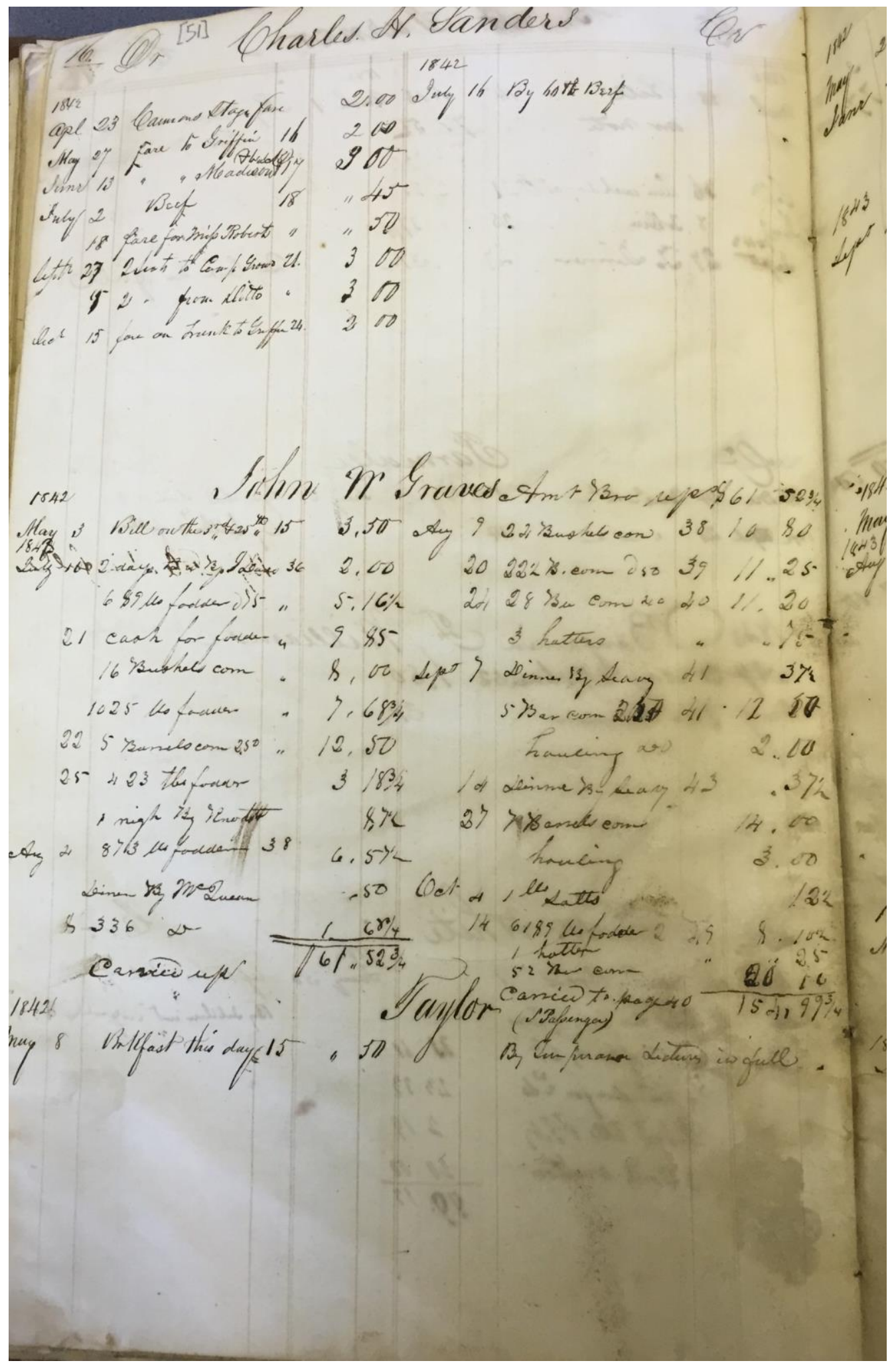


Figure 9: "Young Boy with Whip" (1840) by Anonymous. A picture of a young boy whose attire was not only feminine, but who also carries a slave whip as well.

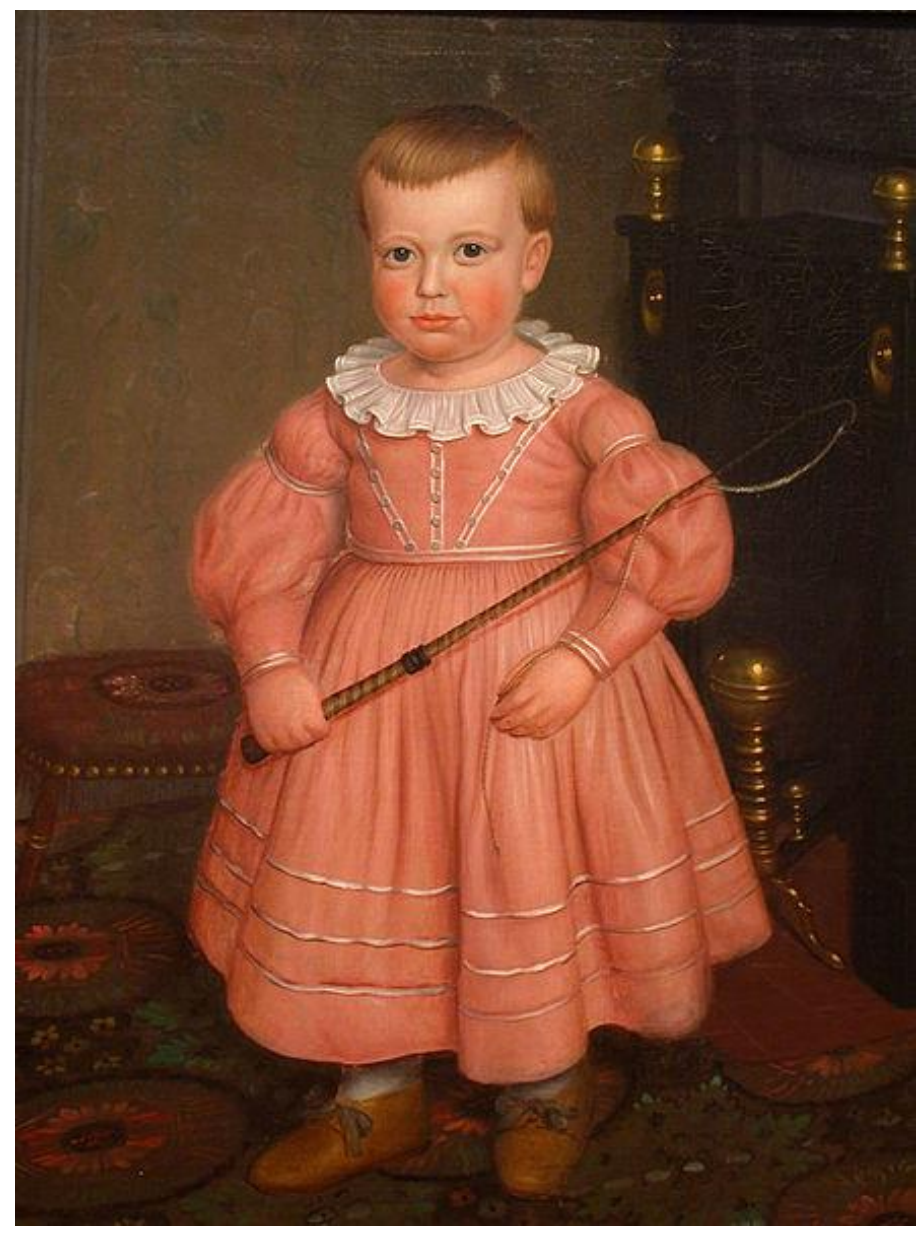

Figure 10: "Payment from Catherine Stone"

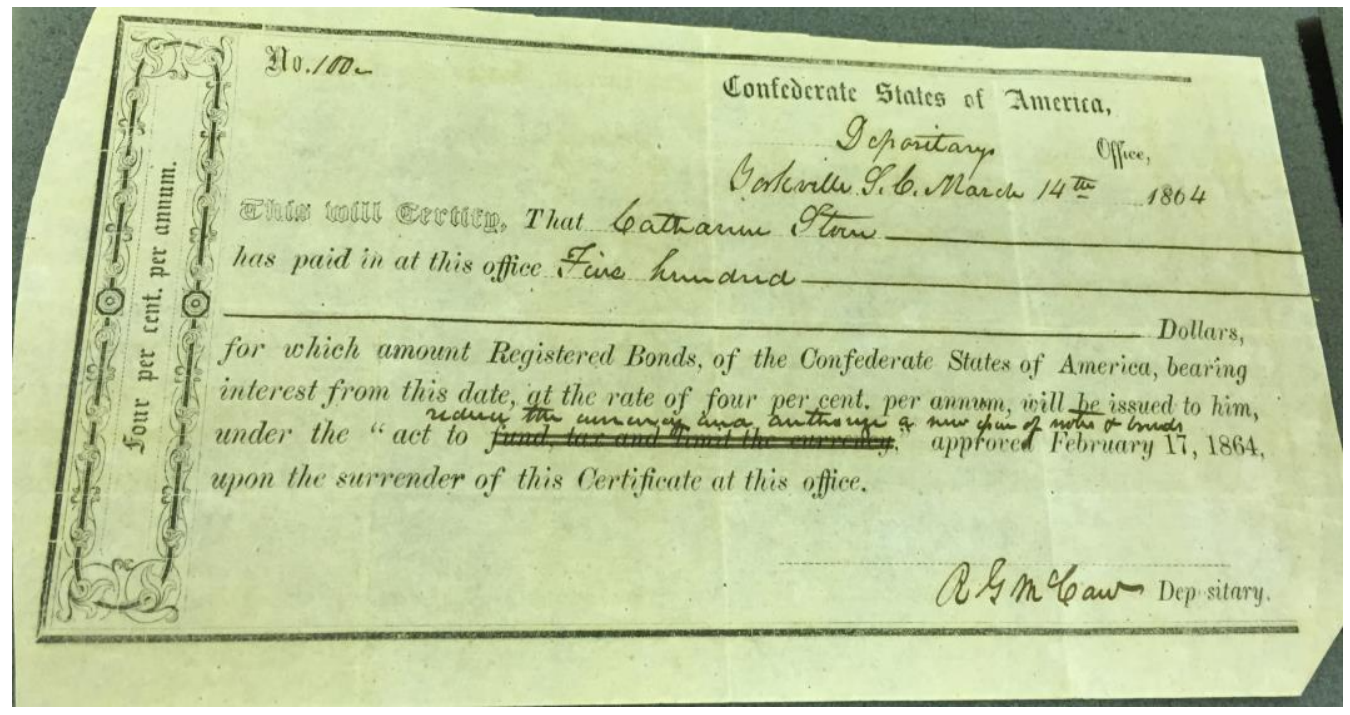


Figure 11: "The Sphere of a Woman" illustration in Godey's Lady's Book (March 1850).
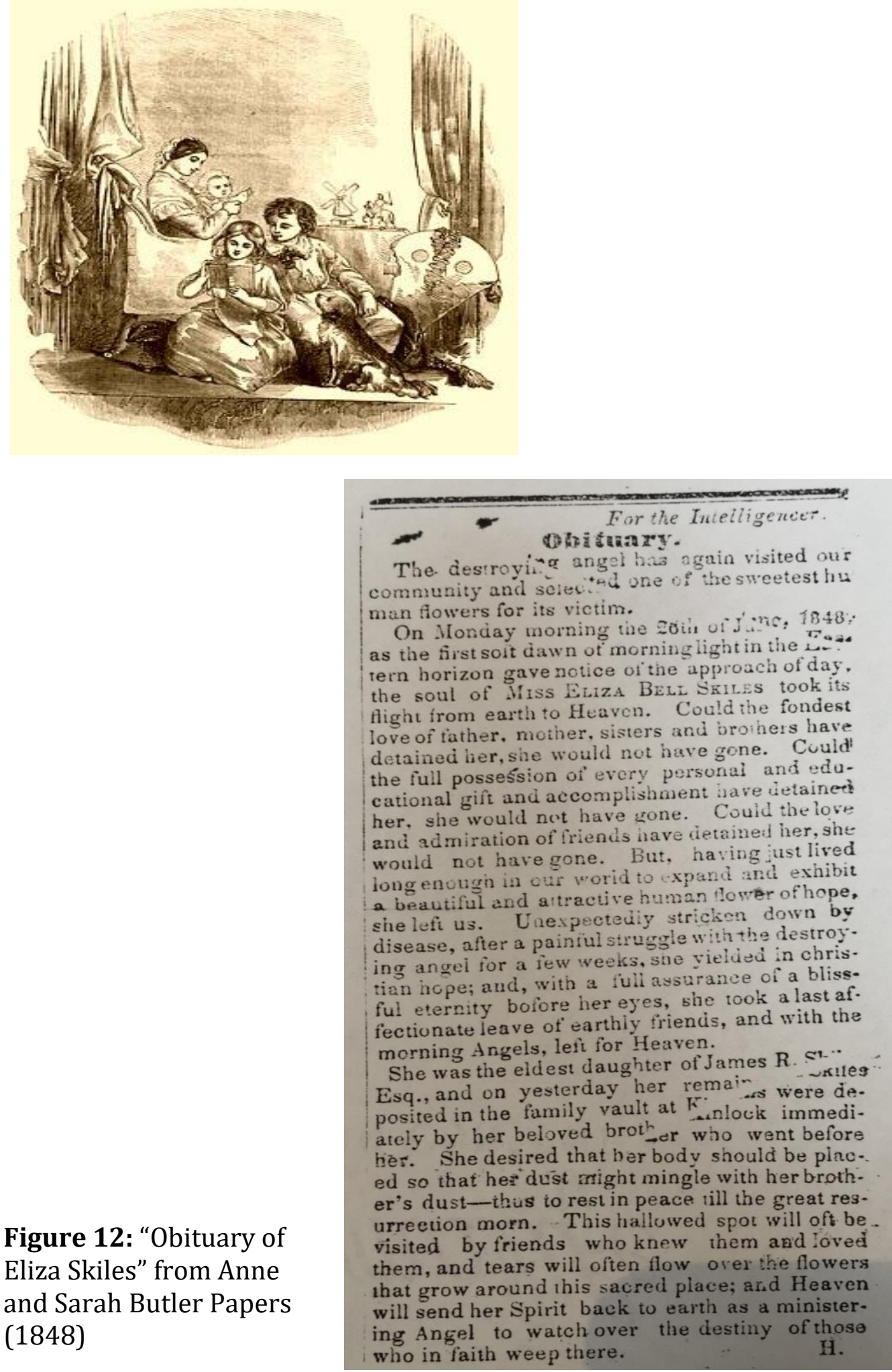

Figure 12: "Obituary of Eliza Skiles" from Anne and Sarah Butler Papers (1848) who in faith weep there. 
Figure 13: "Proclamation Concerning Nat Turner by Governor Floyd" (17 September 1831" Via Library of Virginia.

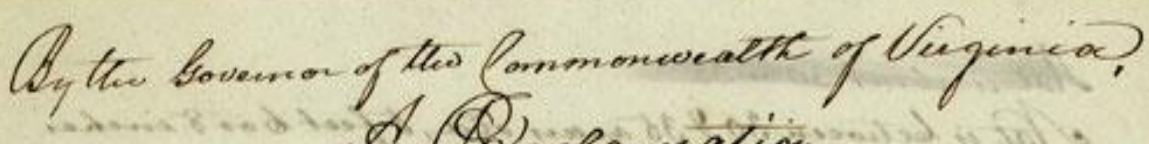
As oclamation.

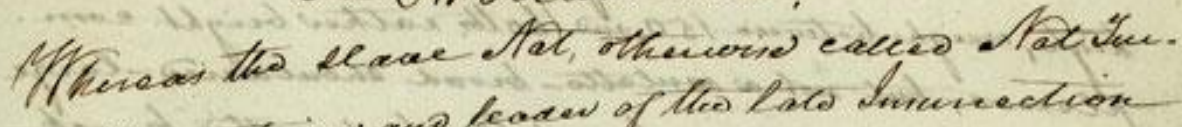

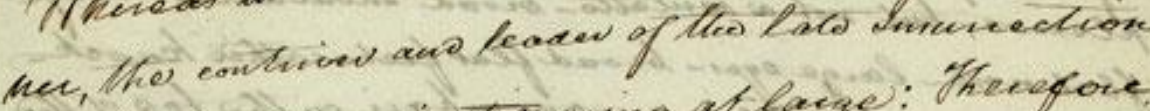

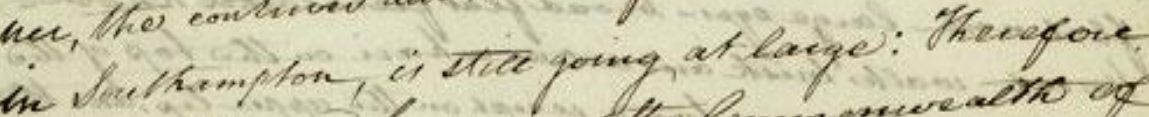

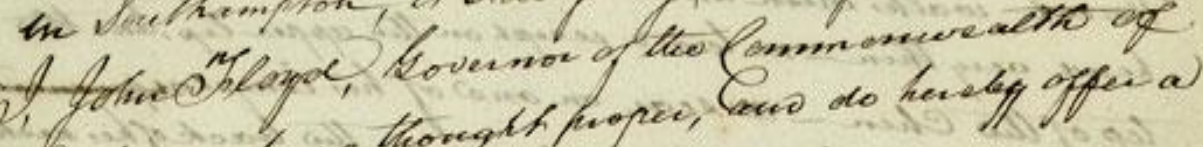

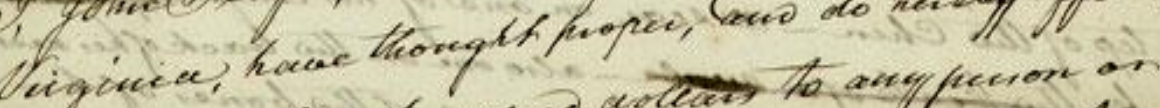

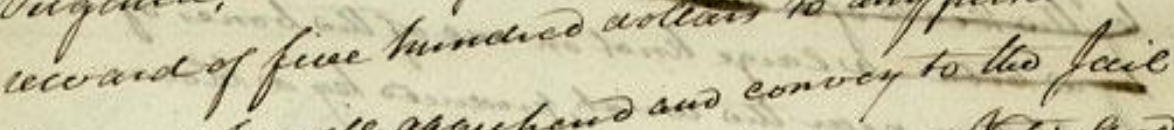

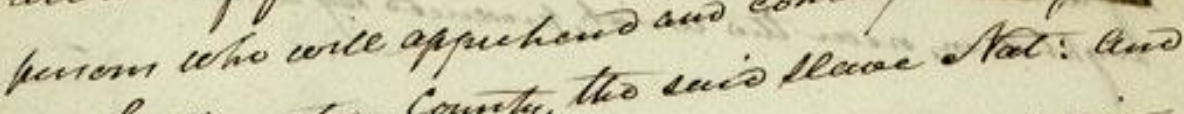

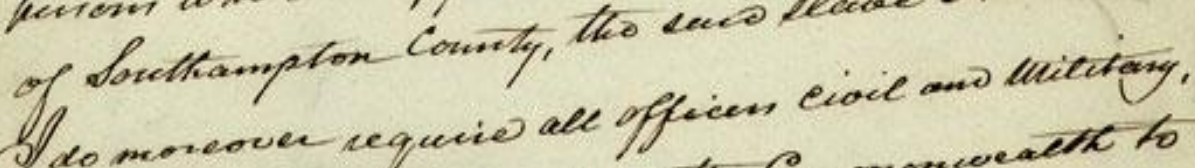

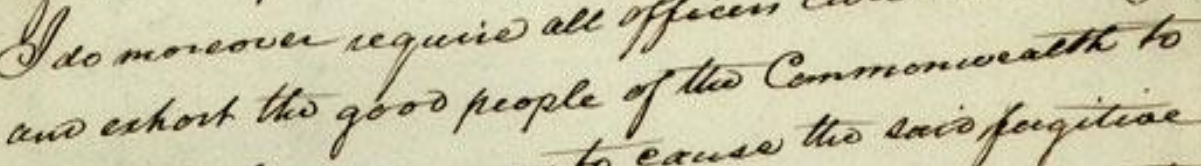

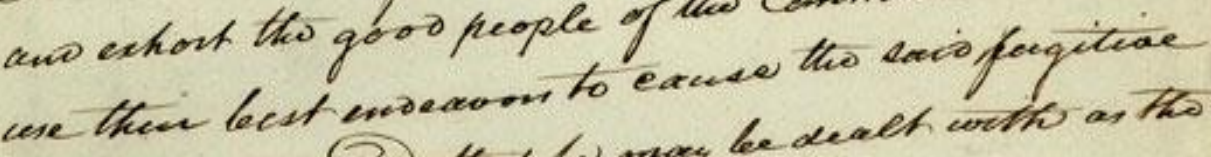
to be epputherded, that he many be death woth ar the Cecoo deicets.

1

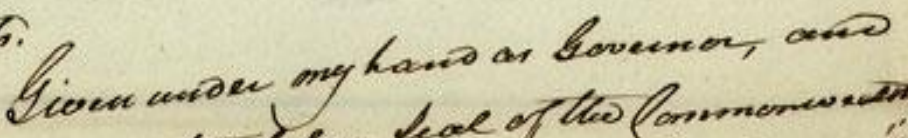

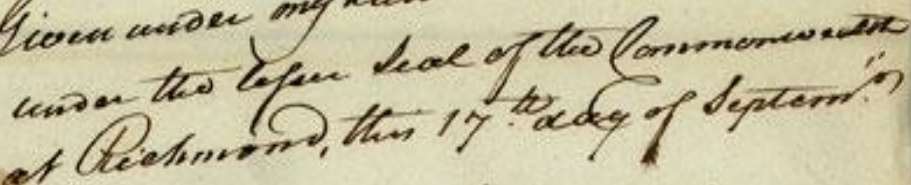
1831




Figure 14: Petition from "Females of the County of Augusta" to the General Assembly (19 January 1832) that declares their intentions to fight for the rights of African American's.
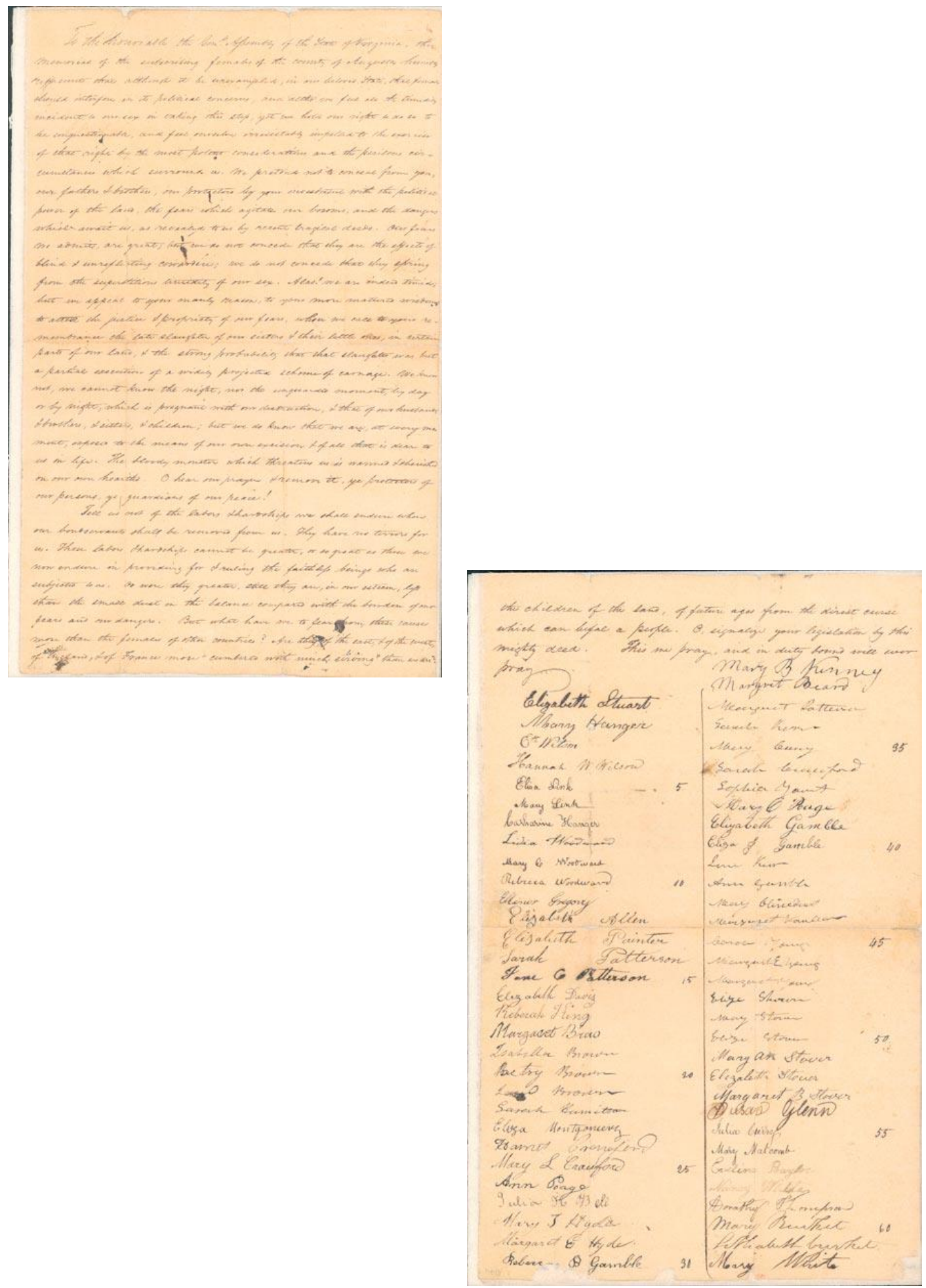


\section{Figure 15: "A Brief History of the Presbyterian Church, in Petersburg" (1833) that speaks about the importance of women to their efforts.}



18. Tract Distribution Soriety-Mrs. Phebe HE in, irewarur.

19. House of Industry-A. S. Holderby, Treasurer, and L. G. Plemer, 1st Directress.

20. Dorcas Society-Mirs. Holderby, Treasurer. 21. Orjhans' Asylum-WM. HAXALL, Treasurer. 22. Lducation Society-Mirs. S. C. BoTT, Direciress.

23. Subscription to Union Theological Seminary: Hegh Nelson, Loeal Agert.

24. Subscriptiou to Generdl Assembly's Board of Education, obtainéd by Mr. Chester: Hugh NeLson, Local Agent.

25. Petersburg Temperance Society: Constitution, \&c., kept by L'ARCy PAUL, Secretary.

26. Collection, the 1st Sabbath of every month, for Contingent Fund of the Congregation.

27. Collection; on the Sabbath nearest the Fourth of July, for Colonization Society.

28. Monthly Concert of Prayer, for the Conversion of the World, observed regulariy in the Church, and Collections raised for Missions.

29. John E. Lemorne, Treasurer of the Board of 'Tristees of the Church.

30. Hugh Nelson, Clerk of Session.

\section{H $\mathrm{Y}$ 证 $\mathrm{N}$.}

Am I a soldier of the cross; A follower of the Lamb,

And shail I fear to own his cause, Or blush to speak his name?

Shall I be carried to the skies, On flowery beds of ease, E 
Figure 16: The Grimke Sisters (Sarah and Angelina)

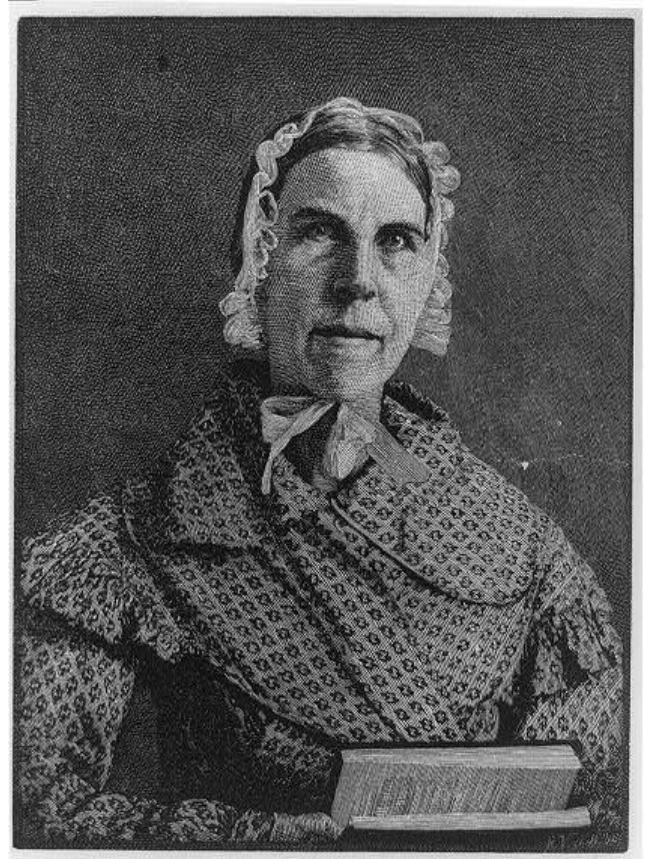

Sarade Mlo. Eninabié,

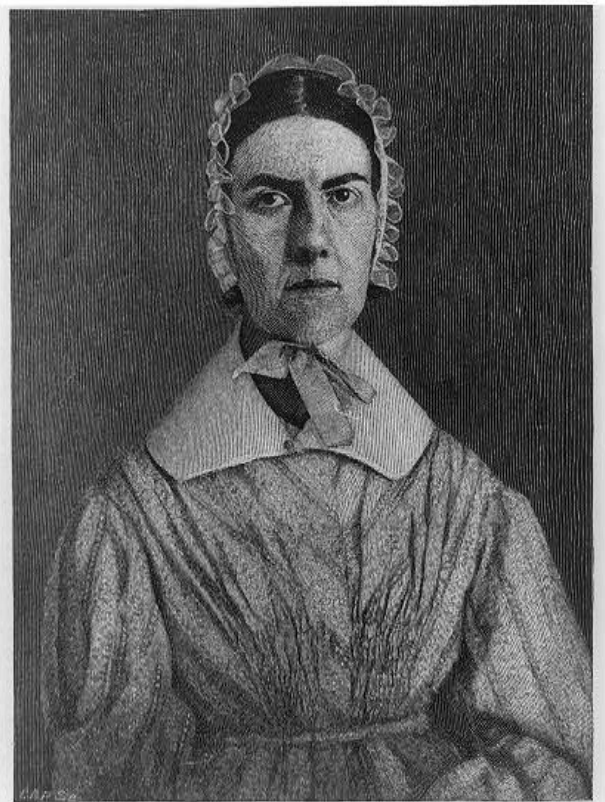

AB Frinte

Figure 17: "Colonial Woman on Farm" by P. Crayon in The Old South Illustrated.

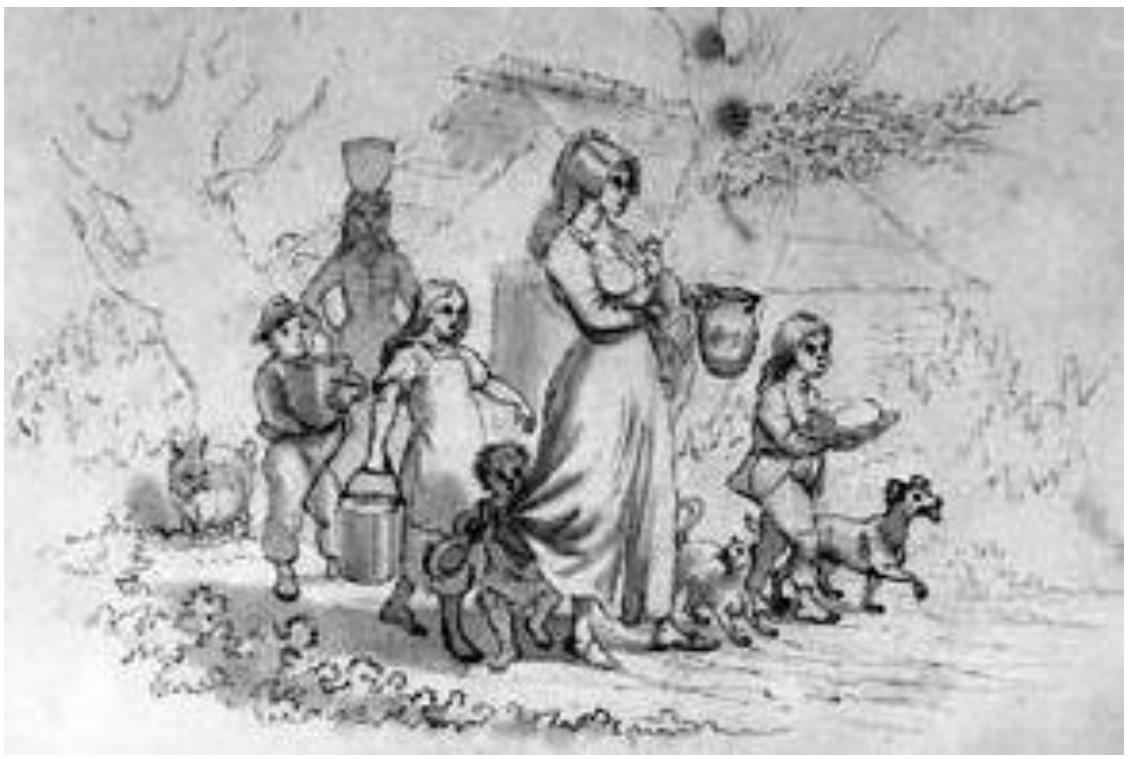


Figure 18: Fertility Chart in Daniel Blake Smith Essay.

\begin{tabular}{lccccc|}
\hline \multicolumn{5}{c|}{ TABLE 3 } \\
\multicolumn{7}{c}{ Total Fertility } & Rates (TFR) for Whites, $1800-1968$ & \\
Year & TFR & Year & TFR & Year & TFR \\
& & & & & \\
1800 & 7.04 & 1860 & 5.21 & 1920 & 3.17 \\
1810 & 6.92 & 1870 & 4.55 & 1930 & 2.45 \\
1820 & 6.73 & 1880 & 4.24 & 1940 & 2.19 \\
1830 & 6.55 & 1890 & 3.87 & 1950 & 3.00 \\
1840 & 6.14 & 1900 & 3.56 & 1960 & 3.52 \\
1850 & 5.42 & 1910 & 3.42 & 1968 & 2.36 \\
\hline
\end{tabular}

Figure 19: Dolly Lunt Burge Portrait

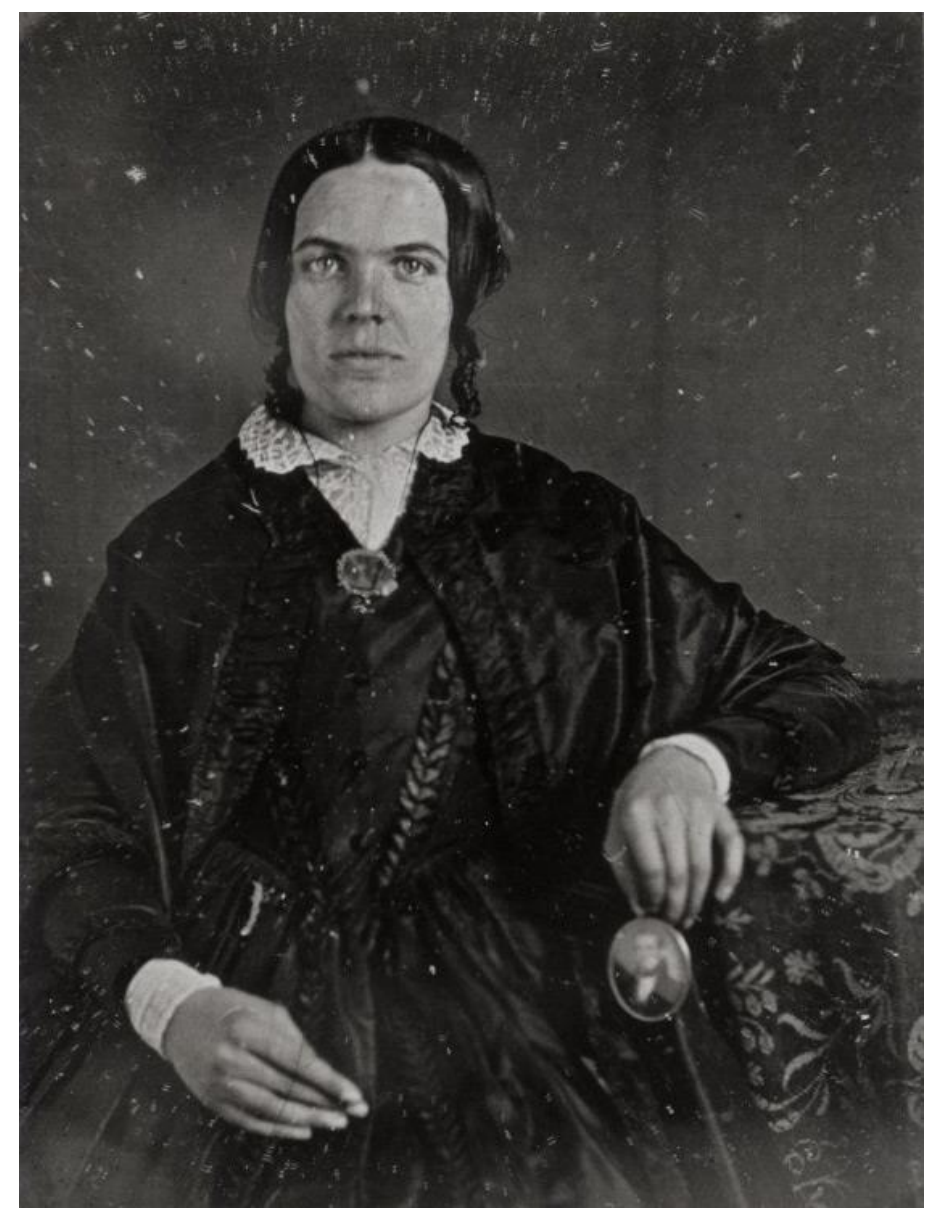


Figure 20: Anna Matilda Page King

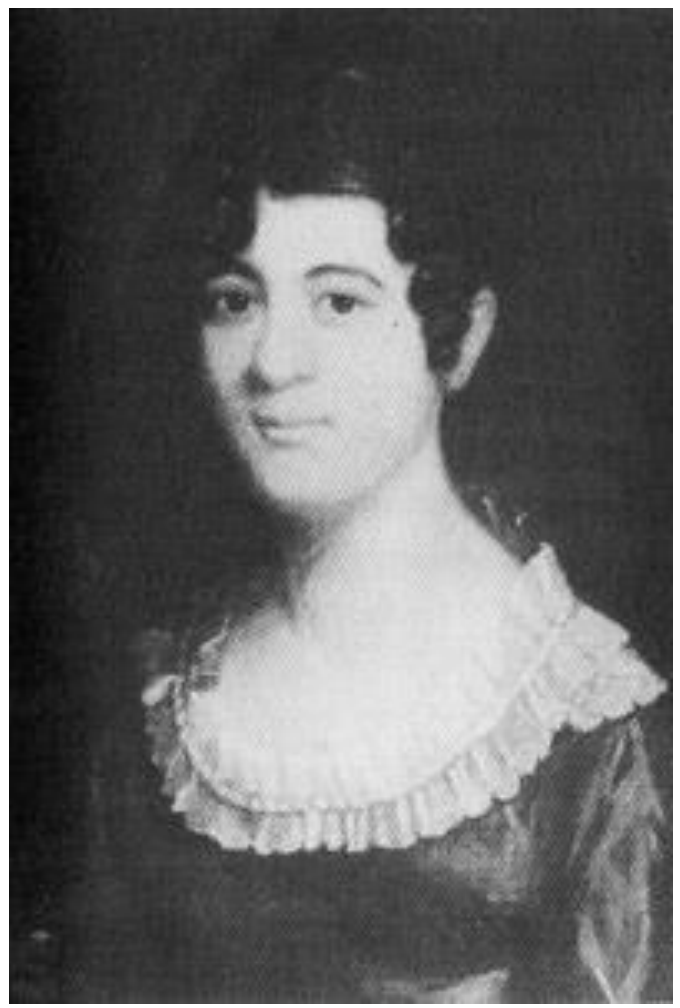

Figure 21: Keziah Goodwyn Hopkins Brevard

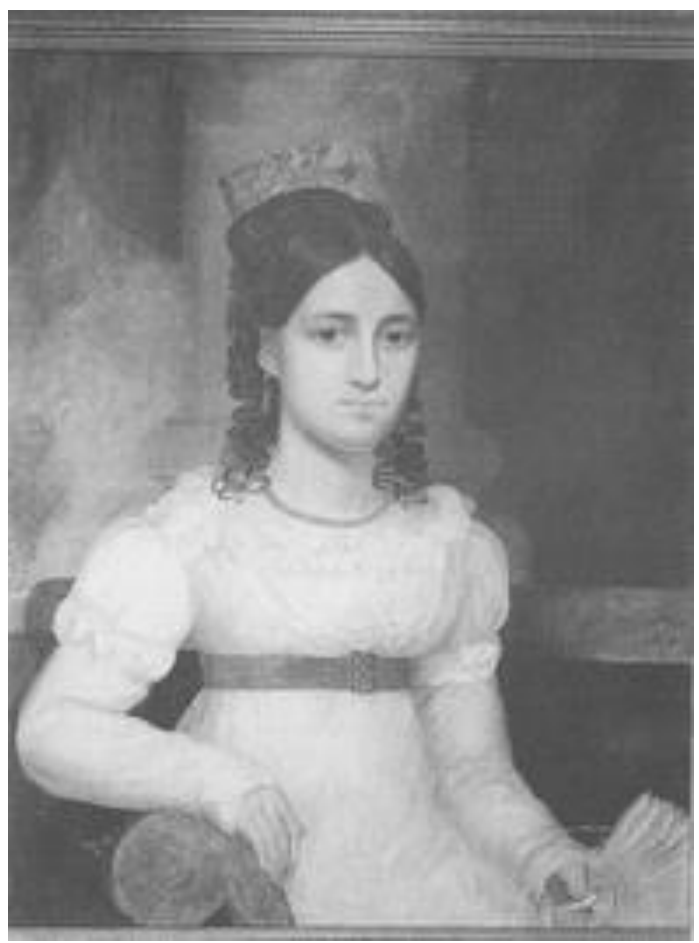


Figure 22: Rosalie Stier Calvert and Child.

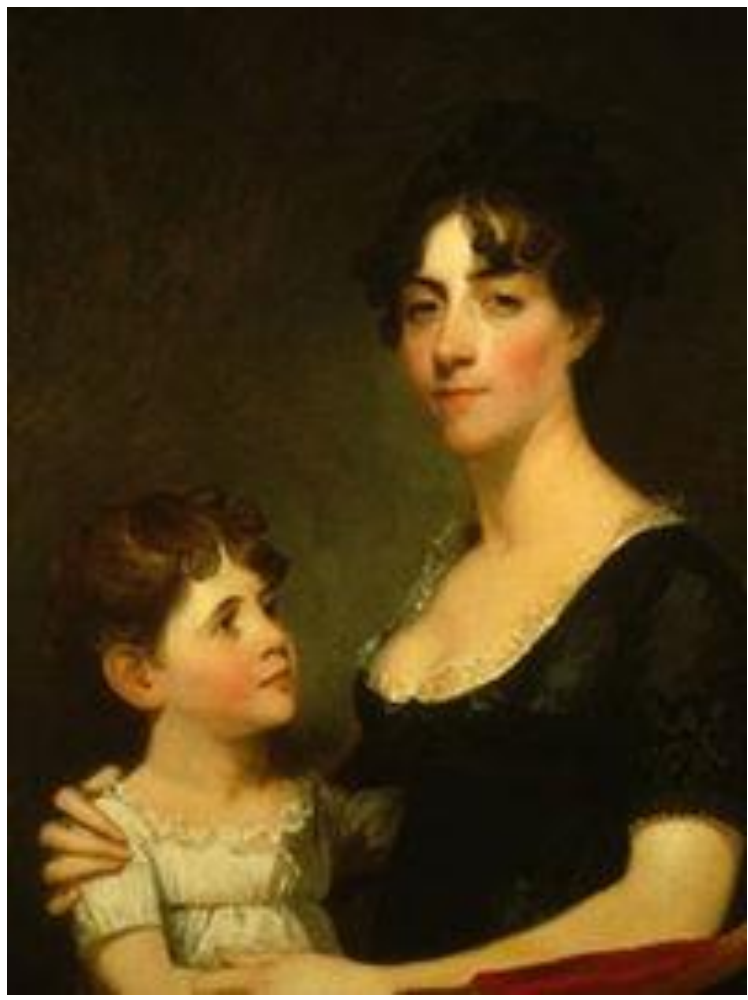

Figure 23: Mrs. Benjamin Tallmadge and Children Henry (3) and Marie (1) (Connecticut, Ralph Earl, 1790)

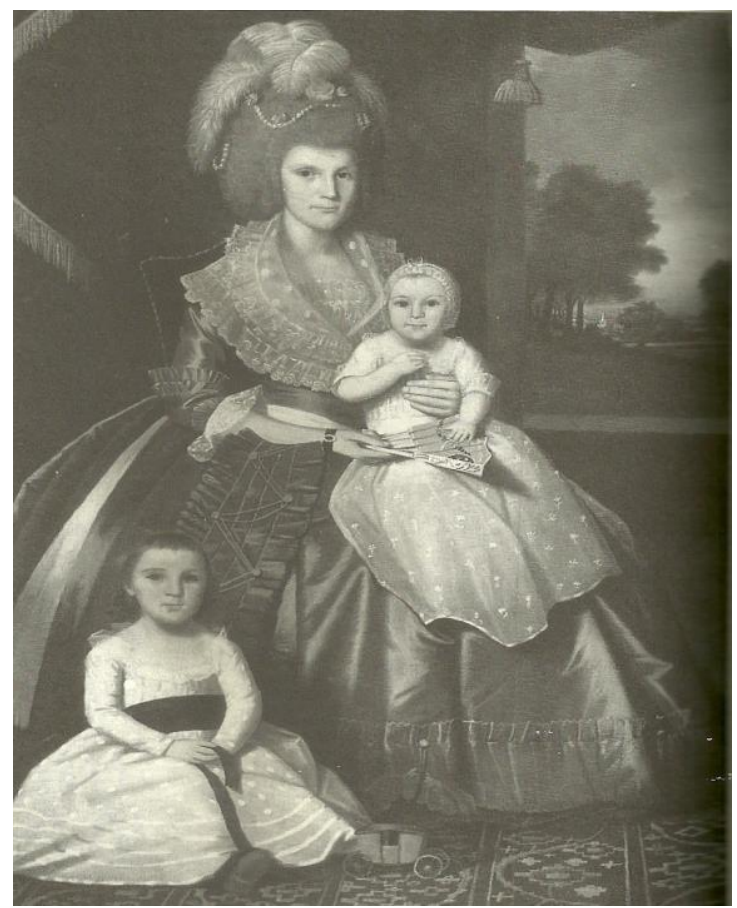


Figure 24: Boy's Tunic Dress in Godey's Lady's Magazine (August, 1859) and Promenade Dress for the Boy and Girl in Godey's Lady's Magazine (December, 1860).
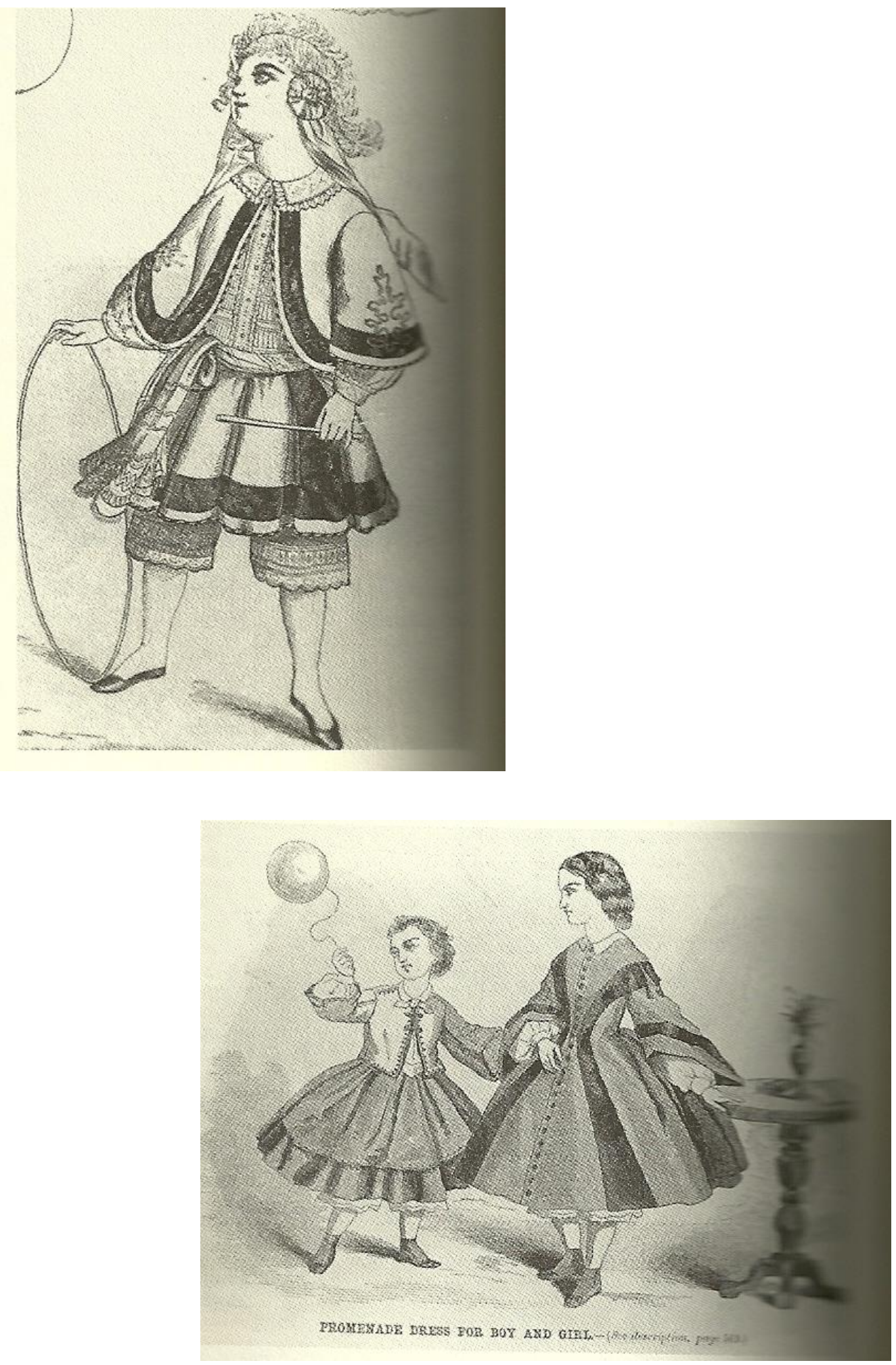


\section{BIBLIOGRAPHY}

\section{PRIMARY SOURCES}

African Repository V.5 (1830) <http://babel.hathitrust.org> .

"American Gardener's Magazine and Register" (1845) in the Special Collections and Archives Research Center at Oregon State University. Accessed: February $14,2016$.

The Family Kitchen Gardener (1847) in the Special Collections and Archives

Research Center at Oregon State University. Accessed: February 14, 2016.

Annual Report of the American Colonization Society (1823) at

$<$ https://books.google.com>.

Bateman, Mary. Diary (11 February 1856) in the Mss. 661, Louisiana and Lower Mississippi Valley Collections, LSU Libraries, Baton Rouge, La.

Blackford, Mary. "The Memorial of the Female Citizens of Fredericksburg" (1831-32) in the Blackford Family Papers \#1912, Southern Historical Collection, The Wilson Library, University of North Carolina at Chapel Hill.

Bleser, Carol. Ed. Tokens of Affection: The Letters of a Planter's Daughter in the Old South (Athens: The University of Georgia Press, 1996).

Bristol Parish Vestry Book (17 June 1840).

Bridgeman, Thomas. "The Young Gardener's Assistant." (1845) in the Special Collections and Archives Research Center at Oregon State University (February 14, 2016). 
Burr, Virginia Ingraham. Ed. The Secret Eye: The Journal of Ella Gertrude Clanton Thomas, 1848-1889 (Chapel Hill: The University of North Carolina Press, 1990).

Burwell, Letitia M. A Girl's Life in Virginia Before the War (New York:

Frederick A. Stokes Company, 1895) in Documenting the American South, UNC: Chapel Hill.

Calcott, Margaret Law. Ed. Mistress of Riversdale: The Plantation Letters of Rosalie Stier Calvert, 1795-1821 (Baltimore: John Hopkins University Press, 1991).

Carter, Christine. Ed. The Dolly Lunt Burge, 1848-1879 (Athens: University of Georgia Press, 2006).

Clay, Henry. "An Address Delivered to the Colonization Society of Kentucky" (Lexington: American Colonization Society, 1829).

Conner, Juliana Margaret. Diary (1827) in Juliana Margaret Courtney Conner Diary \#174-z, Southern Historical Collection, The Wilson Library, University of North Carolina at Chapel Hill.

Cuffee, Captain Paul. A Black Colonizationist: Memoir of Captain Paul Cuffee, A Man of Colour-To which is Subjoined the Epistle of the Society of Sierra Leone in African and Etc. (York: W. Alexander, 1812) in the Rare Books and Special Collections Division of the Library of Congress.

Edmondson, Catherine. Diary (1860) in the James Welch Patton Papers \#3971, Southern Historical Collection, Wilson Library, University of North Carolina at Chapel Hill.

Eliza Ann DeRosset to Mary D. Curtis (29 December 1837) in the M.A. Curtis Papers, \#199, Southern Historical Collection, The Wilson Library, University of North Carolina at Chapel Hill. 
First Baptist Church (Washington Street) "Dorcas Society Minutes" (6 October 1856).

Fuller, Margaret. Women in the Nineteenth Century (New York: Greeley and McElrath, 1845).

Graves, Sarah. "Account Book" (1836-1843) in the Graves Family Papers \#2716, Southern Historical Collection, The Wilson Library, University of North Carolina at Chapel Hill.

Grimball, Meta Morris. Diary (10 December 1860) in UNC: Documenting the American South.

Grimke, Angelina. Appeal to Christian Women of the South (New York: American Anti-Slavery Society, 1836).

Grimke, Sarah. Letters on the Equality of the Sexes, and the Condition of Women: Addressed to Mary S. Parker, President of the Boston Female Anti-Slavery Society (Boston I: Knapp, 1838).

Hammond, John. Ed. A Plantation Mistress on the Eve of the Civil War: The Diary of Keziah Goodwyn Hopkins Brevard, 1860-1861 (Columbia: University of South Carolina Press, 1993).

Heyward, Lucretia. South Carolina Narratives, vol. 15, pt. 2, p. 170 $<$ http://collections.mnhs.org>.

Hilliard, Mrs. Isaac. Diary (1849-1860) in Mrs. Isaac H. Hilliard Diary, Mss. 178, 762, Louisiana and Lower Mississippi Valley Collections, LSU Libraries, Baton Rouge, La.

Laurens, Caroline Olivia. Diary (1823-1827) in the Caroline Olivia Laurens Diary \#3483-z, Southern Historical Collection, The Wilson Library, University of North Carolina at Chapel Hill. 
Liberator (1835) at < fair_use.org>.

Lockridge, Kenneth A. Ed. The Diary and Life of William Byrd II of Virginia, 1674-1744 (Chapel Hill: University of North Carolina Press, 1987).

Mason, Mary Ann. The Young Housewife's Counsellor and Friend: Containing Directions in Every Department of Housekeeping Including the Duties of Wife and Mother (New York: E. J. Hale and Son, 1875).

McCorkle, Lucilla Gamble. Diary (14 June 1846) and (26 July 1846) in the William P. McCorkle Papers \#450, Southern Historical Collection, The Wilson Library, University of North Carolina at Chapel Hill.

Merrick, Caroline E. Old Times in Dixie Land: A Southern Matron's Memories (New York: The Grafton Press, 1901) in Documenting the American South, UNC: Chapel Hill.

Mitchel, Eliza Pearson. Diary (1834) in the Person Family Papers \#590, Southern Historical Collection, The Wilson Library, University of North Carolina at Chapel Hill.

Moore, John Hammond. Ed. A Plantation Mistress on the Eve of the Civil War, 1860-1861 (Columbia: University of South Carolina Press, 1993), 104; Thomas Diary, (18 March 1852).

New Orleans Bee. "The Conflagration at the House Occupied by the Woman Lalaurie" (April 11, 1834).

Pavich-Lindsay, Melanie. Ed. Anna: The Letters of a St. Simons Island Plantation Mistress, 1817-1859 (Athens: University of Georgia Press, 2002).

Pleasants, Sally McCarty B. Old Virginia days and ways; reminiscences of Mrs. Sally McCarty Pleasants (1833) (Menasha: George Banta Publishing 
Company, 1916), Retrieved from the Library of Congress: February 14, 2016.

Pillsbury, Rebecca S. C. Diary \#3470 in the Southern Historical Collection, The Wilson Library, University of North Carolina at Chapel Hill.

Republic of Liberia Drawn Under Superintendence of Com. Lynch. Map. Library of Congress: Geography and Map Division, USN, 1853.

The African Intelligencer. vol. 1, (1820) in Journal Rare Book and Special Collections Division, Library of Congress.

Southern Lady's Companion. vol. 1, (Apr. 1847-Mar. 1848) at $<$ http://hdl.handle.net>.

Southern Rose (1835) Charleston, South Carolina: (J.S. Burges and others).

Sumter, Natalie de Delage. Diary (21 July 1840-22 July 1840) in Louisiana and Lower Mississippi Valley Collections, LSU Libraries, Baton Rouge, Louisiana.

Stone, Catherine. "Business Transaction" (10 February 1847) in Stone Family Paper, Southern Historical Collection, The Wilson Library, University of North Carolina at Chapel Hill.

"Student Compositions" in Iverson Papers, Southern Historical Collection, The Wilson Library, University of North Carolina at Chapel Hill.

Wadley, Sarah. Diary (1860) in the Sarah Lois Wadley Papers \#1258, Southern Historical Collection, The Wilson Library, University of North Carolina at Chapel Hill.

Weld, Theodore Dwight. American Slavery As It Is: Testimony of A Thousand Witnesses (New York: American Slavery Society, 1839). 
Wiley, Bell Irvin. Slaves No More: Letters from Liberia, 1833-1869 (Knoxville: University Press of Kentucky, 1980).

\section{MANUSCRIPTS}

American Colonization Society Papers Manuscript Division, Library of Congress

Anna and Sarah Butler Correspondence, Mss. 581, Louisiana and Lower Mississippi Valley Collections, LSU Libraries, Baton Rouge, Louisiana.

Beale and Davis Family Papers \#2572, Southern Historical Collection, The Wilson Library, University of North Carolina at Chapel Hill.

Blackford Family Papers \#1912, Southern Historical Collection, The Wilson Library, University of North Carolina at Chapel Hill.

Burwell Family Papers (\#112) 1745-1997, Southern Historical Collection, The Wilson Library, University of North Carolina at Chapel Hill.

Caroline Olivia Laurens Diary \#3483-z, Southern Historical Collection, The Wilson Library, University of North Carolina at Chapel Hill.

Caswell County Historical Association Collection \#5401, Southern Historical Collection, The Wilson Library, University of North Carolina at Chapel Hill.

Charles Iverson Graves Papers \#2606, Southern Historical Collection, The Wilson Library, University of North Carolina at Chapel Hill.

Cobb Family Papers \#4008, Southern Historical Collection, The Wilson Library, University of North Carolina at Chapel Hill. 
Elizabeth Washington Grist Knox Papers \#4269, Southern Historical

Collection, The Wilson Library, University of North Carolina at Chapel Hill.

George Washington Allen Papers \#2711, Southern Historical Collection, The Wilson Library, University of North Carolina at Chapel Hill.

Iveson L. Brookes Papers \#3249, Southern Historical Collection, Wilson Library, University of North Carolina at Chapel Hill.

James Welch Patton Papers \#3971, Southern Historical Collection, Wilson Library, University of North Carolina at Chapel Hill.

Joyner Family Papers \#4428, Southern Historical Collection, The Wilson Library, University of North Carolina at Chapel Hill.

Juliana Margaret Courtney Conner Diary \#174-z, Southern Historical Collection, The Wilson Library, University of North Carolina at Chapel Hill.

Graves Family Papers \#2716, Southern Historical Collection, The Wilson Library, University of North Carolina at Chapel Hill.

Leake Family Estate Papers, \#1250, Southern Historical Collection, The Wilson Library, University of North Carolina at Chapel Hill.

Margaret Mordecai Devereux Papers \#2492-z, Southern Historical Collection, The Wilson Library, University of North Carolina at Chapel Hill.

Marshall-Furman Family Papers, Louisiana and Lower Mississippi Valley Collections, LSU Libraries, Baton Rouge, Louisiana.

Mrs. Isaac H. Hilliard Diary, Mss. 178, 762, Louisiana and Lower Mississippi Valley Collections, LSU Libraries, Baton Rouge, La. 
Person Family Papers \#590, Southern Historical Collection, The Wilson Library, University of North Carolina at Chapel Hill.

Purrington Family Papers \#5447, Southern Historical Collection, The Wilson Library, University of North Carolina at Chapel Hill.

Randolph and Yates Family Papers \#1998-z, Southern Historical Collection, The Wilson Library, University of North Carolina at Chapel Hill.

Sarah Lois Wadley Papers \#1258, Southern Historical Collection, The Wilson Library, University of North Carolina, Chapel Hill.

Savannah Home for Girls Papers \#692, Georgia Historical Society, Savannah, Ga.

Stone Family Paper, Southern Historical Collection, The Wilson Library, University of North Carolina at Chapel Hill.

Sumter, Natalie deLage. Diary (1840-1841), Sumter District, South Carolina [microform].

Walton Family Papers \#1437, Southern Historical Collection, The Wilson Library, University of North Carolina at Chapel Hill.

William Gaston Papers, \#272, Southern Historical Collection, The Wilson Library, University of North Carolina at Chapel Hill.

William P. McCorkle Papers \#450, Southern Historical Collection, The Wilson Library, University of North Carolina at Chapel Hill.

M.A. Curtis Papers, \#199, Southern Historical Collection, The Wilson Library, University of North Carolina at Chapel Hill. 


\section{SECONDARY SOURCES}

Baptist, Edward E. The Half Has Never Been Told: Slavery and the Making of American Capitalism (New York: Basic Books, 2014).

Bellamy, Donnie D. and Diane E. Walker. "Slaveholding in Antebellum Augusta and Richmond County, Georgia" (Phylon: Clark Atlanta University, 1987).

Berkin, Carol. First Generations: Women in Colonial America (New York: Hill and Wang, 1996).

Beyan, Amos J. The American Colonization Society and the Creation of the Liberian State: A Historical Perspective, (New York: University Press of America, 1991).

Birney, Catherin H. The Grimke Sisters (Whitefish: Kessinger Publishing, 2004).

Boydston, Jeanne. Home and Work: Housewives, Wages, and the Ideology of Labor in the Early Republic (Oxford: Oxford University Press, 1990).

Breen, T.H. Tobacco Culture: The Mentality of the Great Tidewater Planters on the Eve of Revolution (Princeton: Princeton University Press, 1985).

Brown, Kathleen. Good Wives, Nasty Wenches, and Anxious Patriarchs: Gender, Race, and Power in Colonial Virginia (Chapel Hill: University of North Carolina Press, 1996).

Burin, Eric. Slavery and the Peculiar Solution: A History of the American Colonization Society (Southern Dissent) (Gainesville: University Press of Florida, 2008). 
Caldwell, Lee Ann. "New Deal on a New Frontier: European Women Colonists and Trustee Policy, 1733-1752" in the Journal of the Georgia Association of Historians 16 (1995).

Caldwell, Lee Ann. "Women in Colonial Georgia" (New Georgia Encyclopedia, 09 December 2015), Accessed: 27 February 2016.

Caldwell, Lee Ann. "Women Landholders of Colonial Georgia" in Forty Years of Diversity: Essays on Colonial Georgia, Eds. Harvey H. Jackson and Phinizy Spalding (Athens: University of Georgia Press, 1984).

Calvert, Karin. Children in the House: The Material Culture of Early Childhood, 1600-1900 (Boston: Northeastern University Press, 1992).

Cazden, Elizabeth. Antoinette Brown Blackwell: A Biography (New York: The Feminist Press, 1983).

Chirhart, Ann Short and Betty Woods. Eds. Georgia Women: Their Lives and Times, vol. 1 (Athens: University of Georgia Press, 2009).

Clinton, Catherine. The Plantation Mistress: Women's World in the Old South (New York: Pantheon Books, 1982).

Cott, Nancy. The Bonds of Womanhood: “Woman's Sphere" in New England 1780-1835 (New Haven: Yale University Press, 1977).

Craven, Wesley F. The Southern Colonies in the Seventeenth Century, 16071689: A history of the South (Baton Rouge: Louisiana State University Press, 1949).

Crawford, Stephen C. "Punishments and Rewards" in The Rise and Fall of American Slavery: Without Consent or Contrast. Eds. Robert Fogel and L. Engerman (New York: W. W. Norton, 1989). 
David, John She. The American Colonization Society: And the Founding of the First African Republic (Bloomington: iUniverse LLC, 2014).

Davis, Harold E. The Fledgling Province: Social and Cultural Life in Colonial Georgia (Chapel Hill: University of North Carolina Press, 1976).

Demos, John. A Little Commonwealth: Family Life in Plymouth Colony (Oxford: Oxford University Press, 2000).

Egerton, Douglas R. "'Its Origin Is Not a Little Curious': A New Look at the American Colonization Society" (1985) in the Journal of the Early Republic Vol. 5, No. 4, Pp. 463-480.

Fairclough, Norman. Language and Power (Harlow: Pearson Education Limited, 1989).

Faust, Drew Gilpin. Mothers of Invention: Women of the Slaveholding South in the American Civil War (Chapel Hill: University of North Carolina Press, 1996).

Fox-Genovese, Elizabeth. Within the Plantation Household: Black and White Women of the Old South (Chapel Hill: University of North Carolina Press, 1988).

Gallay, Alan. The Indian Slave Trade: The Rise of the English Empire in the American South 1670-1717 (New Haven: Yale University Press, 2002).

Genovese, Eugene D. Roll, Jordan, Roll: The World the Slaves Made (New York: First Vintage Books Edition, 1976).

Gershoni, Yekutiel. Black Colonialism: The Americo-Liberian Scramble for the Hinterland (Boulder: Westview Press, 1985). 
Ginzberg, Lori D. Women and the Work of Benevolence: Morality, Politics, and Class in the Nineteenth-Century United States (New Haven: Yale University Press, 1990).

Glymph, Thavolia. Out of the House of Bondage (Cambridge: Cambridge University Press, 2008).

Goodyear, Alison Freehling. Drifting Toward Dissolution: The Virginia Slavery Debate of 1831-1832 (Baton Rouge: Louisiana State University Press, 1982).

Handall, Stephen R. "Women and Addiction in the United States-1850 to 1920" (Cambridge: First Harvard University Press, 1999).

Holland, Dorothy, William Lachicotte Jr., Debra Skinner, and Carol Cain. Identity and Agency in Cultural Worlds (Cambridge: Harvard University Press, 1998).

Janney, Caroline. Burying the Dead But Not The Past (Chapel Hill: University of North Carolina Press, 2008).

Kahn, Charles. "An Agency Theory Approach to Slave Punishment and Rewards" in The Rise and Fall of American Slavery: Without Consent or Contrast. Eds. Robert Fogel and L. Engerman (New York: W. W. Norton, 1989).

Lebsock, Suzanne. A Share of Honour: Virginia Women, 1600-1945 (Richmond: Virginia Women's Cultural History Project, 1984). The Free Women of Petersburg: Status and Culture in a Southern Town, 1784-1860 (New York: W.W. Norton \& Company, 1985).

Levy, Barry. Quakers and the American Family: British Settlement in the Delaware Valley (Oxford: Oxford University Press, 1988). 
Long, Carolyn Morrow. Madame Lalaurie, Mistress of the Haunted House (Gainesville: University Press of Florida, 2012).

Love, Victoria Cosner and Lorelei Shannon. Mad Madame Lalaurie: New Orleans Most Famous Murderess Revealed (Charleston: The History Press, 2011).

Marsh, Ben. Georgia's Frontier Women: Female Fortunes in a Southern Colony (Athens: University of Georgia Press, 2007).

Mitchell, Patricia B. At the Table in Colonial America: 1700-1776 (SimsMitchell House \& Breakfast, 1999).

Morgan, Edmund S. American Slavery, American Freedom (New York: W.W. Norton \& Company Inc., 1975).

Morton, Patricia. "'My Ol' Black Mammy in American Historiography" in Southern Women. Ed. Caroline Matheny Dillman (New York: Hampshire Co., 1988).

Perry, Mark E. Lift Up Thy Voice: The Grimke Family's Journey from Slaveholders to Civil Rights Leaders (New York: Viking Penguin, 2002).

Robinson, Harriet. The American Slave: A composite Autobiography (Greenwood Publishing, 1971), vol. 7, p. 278.

Rutman, Darrett R. A Place in Time: Middlesex County Virginia (Toronto: George J. Mclead Limited, 1984).

Stansell, Christine. City of Women: Sex and Class in New York, 1789-1860 (Illinois: University of Illinois Press, 1987).

Scott, Anne Firor. The Southern Lady: From Pedestal to Politics, 1830-1930 (Chicago: University of Chicago Press, 1970). 
Smith, Daniel Blake. Inside the Great House: Planter Family Life in EighteenthCentury Chesapeake Society (Ithaca: Cornell University Press, 1980).

Smith, Daniel Scott. "Family Limitation, Sexual Control, and Domestic Feminism in Victorian America" (1973) JSTOR: Journal of Feminist Studies, Vol. 1, No. 3/4, Special Double Issue: Women's History, Pp. 4057.

"Notes on the Measurement of Values" (1985) in the Journal of Economic History, Vol. 45, No. 2, The Tasks of Economic History, pp 213-218.

Smith-Rosenberg, Carroll. Disorderly Conduct: Visions of Gender in Victorian America (New York: Oxford University Press, 1985).

Spalding, Phinizy. Ed. Women on the Colonial Frontier: A Study of Frederica and Early Georgia (St. Simons: Fort Frederica Association and National Park Service, 1995).

Spruill, Julia. Women's Life and Work in the Southern Colonies (New York: W.W. Norton \& Company, 1972).

Staudenraus, P.J. The African Colonization Movement 1816-1865 (New York: Columbia University Press, 1961).

Ulrich, Laurel Thatcher. Good Wives: Image and Reality in the Lives of Women in Northern New England, 1650-1750 (New York: Vintage Books, 1991).

Van Zandt, Abraham Brooks. "The Elect Lady": A Memoir of Mrs. Susan Catherine Bott (Charleston: Nabu Press, 2011). 
Varon, Elizabeth. We Mean to Be Counted: White Women and Politics in Antebellum Virginia (Chapel Hill: University of North Carolina Press, 1998).

Weiner, Marli F. Mistress and Slaves: Plantation Women in South Carolina, 1830-80 (Chicago: University of Chicago, 1998).

Weld, Theodore. American Slavery As It Is: Testimony of a Thousand Witnesses (Westport: Negro University Press, 1970).

White, Deborah Gray. Ar'n't I a Woman? Female Slaves in the Plantation South (New York: Norton \& Company Inc., 1985).

Wood, Betty. The Origins of American Slavery (New York: Hill and Wang, 1991). Slavery in Colonial Georgia, 1730-1775 (Athens: University of Georgia Press, 1984).

Wyatt, Edward A. (1936) “George Keith Taylor, 1769-1815, Virginia Federalist and Humanitarian" in The William and Mary Quarterly 16, Omohundro Institute of Early American History and Culture: 2-18. 